\title{
Tvímælis: \\ Heimspeki menntunar og skólakerfi nútímans
}

Atli Harðarson 
Ritstýrt rit birt 11. desember 2019

\section{Tvímælis: Heimspeki menntunar og skólakerfi nútímans} Atli Harðarson

Abstract

Um höfund

About the author

Heimildir

\section{Ágrip}

Detta rit er inngangur að heimspeki menntunar. Баð inniheldur gagnrýna umfjöllun um hugmyndir sem stundum er gengið að sem gefnum pegar ræett er um skólamál. Detta eru einkum hugmyndir í pá veru að: Dau sem gera námskrár fyrir skóla purfi að velja milli pess að leggja áherslu á námsgreinar og pess að hafa barnið í brennidepli eða bæta samfélagið; skólar eigi að pjóna pörfum nemenda sinna eða hagsmunum atvinnulífsins; hægt sé að skipuleggja nám og kennslu sem sókn að námsmarkmiðum eða hæfniviðmiðum; stjórnvöld geti bætt skóla með fyrirmælum að ofan eða með pví að skapa hagræna hvata; aukin skólaganga bæti efnahag samfélagsins.

Í bókinni eru tólf kaflar og hver peirra lýsir hugtakalegum ógöngum eða rökum sem vísa í ólíkar áttir. Fyrstu fimm kaflarnir sem og kaflar númer níu og tíu fjalla um efni sem liggja á mörkum heimspeki og námskrárfræða. Kaflar númer sex til átta og kafli ellefu snúast um efni á mörkum menntavísinda og stjórnmálaheimspeki. Tólfti og síðasti kaflinn fjallar um fagmennsku kennara.

Hverjum kafla lýkur með spurningum fyrir lesanda. Flestar pessar spurningar snúast um tilgang skóla, skólastefnu og stjórn menntakerfa. Dótt fæstum peirra sé beinlínis svarað er rökstutt að hugsunarleysi um pær ali af sér afglöp í stjórn og uppbyggingu skólakerfisins.

Efnisorð: Heimspeki menntunar, skólakerfi nútímans, námskrárfrææi.

„Að stjórna ríki er eins og að sjóða smáfisk“ (Laozi, 2010, bls. 60). 


\section{Efnisyfirlit}

Inngangur 4

1. Hlutverk skóla 5

2. Frelsi og námsgreinar 11

3. Jöfnuður og námsgreinar 16

4. Darfir atvinnulífsins 22

5. Skólaganga, menntun og siðferði 25

6. Að skrá menntun 33

7. Vandi gagnadrifinnar stjórnsýslu 39

8. Skrifræði og einkavæðing 45

9. Námsmarkmið 53

10. Ólík vensl markmiða og leiða 59

11. Umbætur eða skólapróun 64

12. Fagmennska kennara 69

Eftirmáli - griðastaður pess seinlega 75

Abstract 76

Um höfund/About the author 77

Heimildaskrá

$\begin{array}{ll}\text { Nafnaskrá } & 87\end{array}$ 


\section{Inngangur}

Degar rætt er um skóla er stundum gengið að pví vísu að peir eigi að pjóna hagsmunum nemenda sinna, að starf peirra skuli skipulagt út frá markmiðum, að ríkið geti stjórnað skólakerfinu, að samkeppni milli skóla og eftirlit með peim hvetji pá til að standa sig vel og að aukin skólaganga bæti efnaleg kjör fólks. Svona má lengi telja pví klisjurnar eru margar. Dessi bók fjallar um hvað pær orka tvímælis pegar að er gád.

Efnistökin eru að pví leyti heimspekileg að reynt er að gagnrýna hugtökin sem eru notuð til að fjalla um menntun og skóla og beina athygli að spurningum sem sumar eru barnalega einfaldar en samt erfitt að svara. Detta er eitt af einkennum heimspekinnar. Hún vísar mönnum aftur og aftur á byrjunarreit par sem spurt er um trúverðugleika pess sem mörgum virðist augljóst.

Dótt heimspeki sé stundum talin fjær vettvangi dagsins en flest önnur fræði held ég að fátt sé hagnýtara en að staldra við og vefengja pað sem er álitið sjálfsagt og gert ráð fyrir í hugsunarleysi. Sum afglöpin í stjórn og uppbyggingu menntakerfa eru dýrkeypt og til að forðast pau parf meðal annars að vera spurull að hætti heimspekinga.

Dað er ekki neitt almennt samkomulag um hvaða viðfangsefni falla undir heimspeki menntunar. Menntun fólks og skólaganga er margbrotinn veruleiki og heimspekilegar spurningar sem vakna pegar hann er skoðaður vísa i ýmsar áttir. Ég held að flestir muni pó telja að heimspeki menntunar fjalli bæði um siðfræðileg álitamál sem varða réttlátt skólasamfélag og um ráđgátur sem liggja á mörkum heimspeki og sálfræði og tengjast pví hvernig fólk proskast og lærir. Dessi efni eru pó lítið til umræðu hér. Dau eru hvort um sig efni í aðra bók. Ráðgáturnar sem hér er fjallað um eru ýmist nátengdar stjórnmálafræði og stjórnmálaheimspeki eða á mörkum heimspeki og námskrárfræði. Bókin fjallar pví aðeins um hluta peirra viðfangsefna sem heyra undir heimspeki menntunar. Athyglinni er beint að skólakerfinu fremur en einstaklingunum og einkum að vandamálum sem fara vaxandi og eru áleitin nú um stundir.

\section{Dakkir}

Eftir að ég lauk við drög að öllum köflum pessarar bókar lásu Jón Árni Friðjónsson fyrrum vinnufélagi minn við Fjölbrautaskóla Vesturlands og Ólafur Páll Jónsson samstarfsmaður minn við Menntavísindasvið Háskóla Íslands textann vandlega yfir og bentu mér á margt sem ástæða var til að laga. Um svipað leyti fór bróðir minn, Bjarni Harðarson, yfir handritið og sagði mér bæði hvað rétt væri að skýra betur og hvar pyrfti að bæta mál og stíl. Ég pakka peim fyrir og einnig pakka ég ritstjórunum, Helga Skúla Kjartanssyni og Jóni Torfa Jónassyni en peir lásu handritið eftir að ég skilaði pví til útgefanda og veittu góð ráð um lagfæringar og endurbætur á textanum.

Ráðum sem mér voru gefin fylgdi ég eftir eigin höfði og ég ber einn ábyrgð öllu sem í bókinni stendur.

Sú hjálparhella sem mest hefur munað um er konan mín, Harpa Hreinsdóttir. Hún las textann meðan hann var enn í vinnslu og ábendingar hennar hjálpuðu mér að bæta hann að mun. Pær voru framhald af samræðum okkar um menntun og skóla sem hafa staðið nær óslitið frá pví við hófum bæði störf sem kennarar við Fjölbrautaskóla Vesturlands árið 1986. Hörpu tileinka ég pessa bók. 


\section{Hlutverk skóla}

Á nítjándu öld settu flest lönd Evrópu lög um skólaskyldu fyrir börn. Prússland reið raunar á vaðið allnokkru fyrr en par hófst skólaskylda pegar á átjándu öld. Svipaða sögu er að segja frá Norður-Ameríku. Í Bandaríkjunum var skólaskyldu fyrst komið á í Massachusetts árið 1852. Hin fylkin fylgdu á eftir eitt af öđru og pau síðustu settu lög um skólaskyldu á árunum milli 1910 og 1920. Á Íslandi var tuttugasta öldin gengin í garð pegar Alpingi sampykkti lög um fræðslu barna nr. 59/1907. Með pessum lögum var stefnan tekin á skólakerfi fyrir öll börn pótt pau heimiluðu dreifðum byggðum að uppfylla fræðsluskyldu með öðrum aðferðum en eiginlegu skólahaldi.

Skólaganga barna og unglinga var víða um lönd orðin algeng áður en hún var gerð að skyldu. Sums staðar, til dæmis á Englandi, voru fjölmargir skólar stofnaðir að frumkvæði einstaklinga og reknir sem einkafyrirtæki fyrir daga skólaskyldu (West, 1965/1994; Bowen, 1981; Coulson, 1999; Tooley, 2013). Hér á landi voru líka stofnaðir margir barnaskólar á seinni hluta nítjándu aldar. Sem dæmi má taka barnaskóla á Eyrarbakka 1852, í Reykjavík 1862, á Akureyri 1871 og á Akranesi 1880. Einnig urðu til skólar fyrir eldri nemendur á árunum kringum 1880 eins og til dæmis Kvennaskólinn í Reykjavík, Bændaskólinn í Ólafsdal, Flensborgarskóli og Möðruvallaskóli. Undir aldarlok var pví mikil breyting orðin frá miðri öldinni pegar aðeins voru tveir skólar í landinu, nýstofnaður prestaskóli og Latínuskólinn. Sá síðarnefndi hét raunar Lærði skólinn pótt hann væri oftast kallaður Latínuskólinn. Hann breyttist í Hinn almenna menntaskóla í Reykjavík árið 1904 og heitir nú Menntaskólinn í Reykjavík. Á árabilinu 1830 til 1848 hafði pó starfað barnaskóli í Reykjavík en hann var lagður niður áður en öldin var hálfnuð (Gunnar M. Magnúss, 1939; Kristinn Ármannsson, Einar Magnússon, Guðni Guðmundsson og Heimir Porleifsson, 1975; Bogi Th. Melsteð, 1986; Loftur Guttormsson, 2008a).

Degar leið á tuttugustu öld urðu skólakerfi víða um heim með stærstu verkefnum hins opinbera. Vexti peirra fylgdu átök um hverjir ættu að stjórna peim og hvernig ætti að gera pað. Alla síðustu öld tókust á ólíkar hugmyndir um skólastarf og tilgang pess. Hluti af pessum deilum snerist um annað en eiginlega menntastefnu, svo sem eins og kostnað og mannahald. Detta gildir væntanlega enn pann dag í dag. Í grein um stefnumótun um skólamál hér á landi segir Ólafur Páll Jónsson (2014) til dæmis að síðustu áratugi hafi hún ekki verið eiginleg menntastefna heldur miklu fremur stefna um fjármál og rekstur. Frá upphafi snerist hluti af deilunum pó samt um hvað skólar ættu að gera fyrir nemendur sína og samfélag. Margir fræðimenn hafa reynt að henda reiður á pessum átökum og flokka stefnur í menntamálum í nokkrar ólíkar gerðir (sjá t.d. Eisner og Vallance, 1974; McNeil, 1977; Andri Ísaksson, 1983; Kliebard, 1987; Walker og Soltis, 1997; Schiro, 2008). Algengast er að tala um ferns konar meginsjónarmið:

- Faggreinastefna sem leggur áherslu á að skólar kenni hefðbundin fög eins og stærðfræði, móðurmál, erlend tungumál, sögu og raungreinar. Sum afbrigði pessarar stefnu leggja einkum áherslu á bókleg fræði en önnur hampa einnig listum, handverki og ípróttum. Dessari stefnu hefur oft fylgt áhersla á að grunn- og framhaldsskólar búi nemendur undir nám á háskólastigi. Hún tengist líka oft skoðunum í pá veru að námsgreinarnar hafi eigið gildi en séu ekki aðeins verkfæri til að ná árangri á öðrum sviðum. 
- Darfir og proski nemenda. Um stefnumótun af pessari gerð er notað ýmiss konar orðalag. Stundum er talað um „barnið í brennidepli“" og að koma til móts við áhuga nemenda. Hvernig sem petta er orðað pá er áherslan á að sérhver nemandi njóti sín, dafni og honum farnist vel í skóla. Dessi stefna tengist stundum áherslu á sálfræði sem undirstöðugrein í menntun kennara. Hún tengist líka stundum einstaklingshyggju um menntun sem segir að skólaganga einstaklings eigi einkum að gagnast honum sjálfum.

- Darfir atvinnulifsins og haefni til starfa. Undir pessa stefnu falla ýmsar áherslur á að menntun stuðli að efnalegri velsæld. Hún tengist oft hagfræðilegri sýn á skólastarf og stjórnmálaskoðunum til hægri.

- Umbatur á samfélaginu. Undir pennan flokk fellur meðal annars viðleitni til að nýta skólakerfið til að stuðla að jöfnuði. Hér eiga líka heima nýlegar áherslur á menntun til sjálfbærra lífshátta og tilraunir til að nýta opinber fræðslukerfi til pess að umbylta samfélaginu. Dessi stefna helst oft í hendur við félagsfræðilegt sjónarhorn á skólastarf og stjórnmálaskoðanir til vinstri.

Stundum er pessum áherslum lýst sem andstæðum. Í bók um námskrárfræði frá 2008 sem víða er notuð við kennaradeildir háskóla segir Michael Stephen Schiro til dæmis að pær séu eins og stórir seglar „sem toga okkur sem höfum áhuga á menntamálum í fjórar ólíkar áttir" (Schiro, 2008, bls. 9). Sagnfræðingurinn Herbert M. Kliebard (1987) tekur í sama streng í bók sinni um átök innan bandaríska skólakerfisins frá 1893 til 1958. Hann segir söguna á pá leið að í upphafi hafi faggreinastefnan verið ríkjandi en peir sem fylgdu hinum premur hafi sífellt gert atlögur að henni. Niðurstaða hans er að faggreinarnar hafi staðið allar pessar árásir af sér og haldið áfram að vera ríkjandi í mestöllu skólastarfi.

Prjár síđasttöldu stefnurnar, sem ég tengi við sálfræðilega, hagfræðilega og félagsfræðilega sýn á skólastarf, fjalla um megintilgang skóla og pví verður varla á móti mælt að pær eru ólíkar. Að pær séu ólíkar pýðir pó ekki endilega að pær séu andstæðar. Fyrsta stefnan, faggreinastefnan, virðist líka geta samrýmst öllum hinum og pótt margir talsmenn ólíkra hugmynda um megintilgang skóla hafi andmælt henni er langt frá pví að vera ljóst að áhersla á að kenna til dæmis tungumál og raungreinar stangist á við parfir nemenda og atvinnulífs eða viðleitni til að bæta samfélagið. Hitt virðist sönnu nær að slíkar greinar geti nýst í págu alls pessa.

Á seinni hluta síðustu aldar var Bandaríkjamaðurinn Philip W. Jackson með virtustu fræðimönnum um námskrár- og skólastefnu. Hann fjallaði meðal annars um meinta togstreitu peirra ferns konar sjónarmiða sem hér hafa verið nefnd og sagði að pótt hægt væri að skipta sjónarmiðum og áherslum í nokkra meginflokka fyndist sjaldan eða aldrei fólk sem teldi sig fylgja einni af pessum stefnum og hafna öllum hinum. Að hans dómi blönduðust pær jafnan saman og honum pótti undarlegt í meira lagi að áhersla á námsgreinar væri álitin andstæð áherslum á að nemendur döfnuðu og nytu sín (Jackson, 1992). Á sama hátt má benda á að áherslur á parfir einstaklinga og samfélags geta varla verið algerar andstæður enda er pað væntanlega til góðs fyrir einstaklinga að atvinnulíf gangi vel og samfélagið sé réttlátt og til góđs fyrir samfélag og atvinnulíf að einstaklingunum farnist vel, séu heilbrigðir og hamingjusamir. Í nýlegri bók um skóla og lýðræði rökstyður Guðmundur Heiðar Frímannsson (2018) að skólar purfi að leggja meiri áherslu á borgaramenntun sem styrkir lýðræðislega samfélagshætti og viðheldur peim. Hann ræðir efnið nógu ítarlega til að lesanda megi vera pað ljóst að raunhæfar umbætur í pessa átt pýða ekki að hafna skuli neinum af peim meginsjónarmiðum sem hér hefur verið fjallað um. Að börn menntist til að verða ábyrgir borgarar samrýmist öllum pessum ferns konar menntastefnum enda pjóna góðir skólar margvíslegum tilgangi.

Ef til vill verða pessar ólíku stefnur ekki að eiginlegum andstæðum nema peim sé haldið fram með einstrengingslegum eða öfgafullum hætti. Hér verður litið á tvenns konar mögulega árekstra milli peirra: Annars vegar milli einstaklingshyggju og félagshyggju um menntun og hins vegar milli faggreinastefnu og áherslu á parfir nemenda.

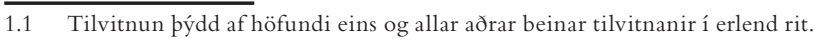




\section{Einstaklingshyggja og félagshyggja um menntun}

Einstaklingshyggja peirra sem leggja áherslu á parfir nemenda tekur á sig ýmsar myndir og sumar gerðir hennar geta stangast á við síðasttöldu stefnurnar tvær enda gera pær báðar ráð fyrir að menntun barns gagnist öđru fólki ekki síður en pví sjálfu. Petta gildir bæði um afstöđu peirra sem vilja laga næstu kynslóð að ríkjandi samfélagsháttum og um róttæk sjónarmið peirra sem vilja að skólarnir breyti samfélaginu.

Pað kann að virðast augljóst mál að margvísleg fræðsla og kennsla pjóni almannahag og hrein og klár einstaklingshyggja sem horfir einungis á hagsmuni nemandans geti ekki gengið. Degar sextán ára unglingum er kennt til bílprófs eru peir látnir læra umferðarreglur og pað er ekki aðeins til að koma í veg fyrir að peir fari sér sjálfir að voða, heldur líka til pess að peir slasi ekki annað fólk. Degar ljósmóðir eða hjúkrunarfræðingur upplýsir verðandi foreldra um hvernig annast skuli hvítvoðung er fræðslunni ætlað að gagnast fleirum en foreldrunum sem njóta hennar, nefnilega barninu. Раð eru jafnvel til námsgreinar í skólum, eins og skyndihjálp, sem gagnast fyrst og fremst öðrum en nemandanum sjálfum. Menn læra ekki hjartahnoð til að lífga sjálfa sig við heldur til að koma öðrum til bjargar.

Í tilviki sumra annarra námsgreina er pað ef til vill ekki jafn augljóst að menntun einstaklings pjóni almannahag. Um leið og við spyrjum okkur fyrir hvern pað er til góðs að barn menntist pá blasir pó við að pað er meðal annars til góðs fyrir maka og börn sem barnið eignast seinna á lífsleiðinni, nágranna, vinnufélaga - og raunar fyrir alla samborgara pess. Dað er hverju okkar til góðs að annað fólk sé menntað. Ég nýt til dæmis góđs af pví að aðrir kunni tannlækningar, rafvirkjun, frönsku og fleiri greinar. Ég nýt líka góðs af pví að stór hluti samborgara minna sé nógu upplýstur til að geta leitt ágreining til lykta með skynsamlegum rökræðum fremur en heimskulegu rifrildi eða of beldi.

Pótt við hljótum öll að viðurkenna að menntun pjóni hagsmunum annarra en nemandans sjálfs er rúm fyrir skynsamlegan ágreining um að hve miklu leyti skólar skuli horfa til hagsmuna hvers einstaklings sem stundar par nám og að hve miklu leyti peir skuli taka mið af almannahag. Um petta eru margir tvístígandi eins og til dæmis enski heimspekingurinn John White sem pekktur er fyrir gagnrýnin skrif um skólakerfi nútímans. White (2005) segir bæði að ákvarðanir um námskrá verði að taka mið af pólitískri sýn á hvað er gott samfélag og að markmið menntunar snúist um velferð nemandans fremur en um skyldur hans við aðra. Á svipuðum nótum talar Sigrún Aðalbjarnardóttir (2007, bls. 95) um pað sem verkefni hvers samfélags , ,að finna jafnvægi milli einstaklingshyggju og samfélagshyggju“.

Sem dæmi um hvernig ólík afstaða í pessum efnum getur haft áhrif á námskrár skóla má nefna spurningu um hvort danska eigi að vera skyldunámsgrein eða valfag í framhaldsskólum. Deir sem telja að hún eigi að vera valfag geta bent á að margir nemendur hafi lítið gagn af kunnáttu í dönsku og muni nota ensku í samskiptum sínum við Dani og aðra Norðurlandabúa. Frá sjónarmiði einstaklingshyggju kann pví að virðast skynsamlegt að danska sé valfag fremur en skyldunámsgrein.

Gegn pessu gæti talsmaður samfélagshyggju bent á að ef danskan væri ekki skylda pá lærðu hana færri. Fyrir vikið færu færri Íslendingar í framhaldsnám á Norðurlöndum, færra fólk á æðstu stöðum í stjórnsýslunni kynntist norrænum jafningjum sínum og lögfræðingar gerðu minna af pví að kynna sér norræna dóma og lög. Til langs tíma yrði afleiðing pess að afnema dönsku sem skyldunámsgrein að öllum líkindum að stjórnsýsla og réttarfar hér á landi yrðu í minna mæli en verið hefur í takti við pað sem gerist á öðrum Norðurlöndum. Deir sem fallast á petta og telja líka að sterk tengsl við norrænar hefðir í stjórnsýslu og réttarfari séu okkur til góðs hafa ástæðu til að vilja að porri unglinga læri dönsku jafnvel pótt stór hluti einstaklinga hafi lítinn beinan hag af pví. Með öðrum orðum má segja að pað sé vel líklegt að margir hafi meiri hag af að dönskukunnátta sé almenn heldur en af pví að kunna sjálfir dönsku. 
Раð er hægt að taka mörg önnur dæmi. Рað kann til dæmis að vera mikilvægt fyrir samfélag að sumir verði undir pað búnir að hefja nám í læknisfræði um tvítugt pótt engin leið sé að vita með margra ára fyrirvara hverjir velja pá námsgrein í háskóla. Ef undirbúningur fyrir læknanám krefst pess að fólk hafi lært efnafræði um árabil pá getur verið mikils um vert fyrir heildina að fleiri kynnist efnafræði á unglingsárum heldur en peir einir sem munu sjálfir hafa bein not af peirri námsgrein.

Eitt af viðfangsefnum menntaheimspeki og stefnumótunar um menntamál er að finna meðalveg milli einstaklingshyggju og félagshyggju um menntun. Detta er erfitt viðfangsefni og hluti vandans er að spurningar um hvað sé einstöku barni í hag tengjast ráđgátum í siðfræði sem hafa vafist fyrir fólki að minnsta kosti síðan grísku heimspekingarnir Platon og Aristóteles skrifuðu um hamingju og farsæld á fjórðu öld fyrir okkar tímatal. Í frægasta riti sínu, Ríkinu, sagði Platon (1991), að siðferðilegir lestir afskræmdu sálina og væru manni sjálfum ævinlega til ills en dygðir, eins og hófsemi, hugrekki, viska og réttlæti, gerðu menn hamingjusama. Nemandi hans, Aristóteles, tók ekki alveg jafn djúpt í árinni pví hann sagði í Siðfreeði Níkomakkosar að ein af dygðunum, réttlætið, væri einkum annarra gæði, til góðs fyrir aðra (Aristóteles, 1995). Hann var pó sammála lærimeistara sínum um að farsæll maður léti sig varða um hag samborgara sinna, pað væri ekki hægt að dafna vel sem einstaklingur án pess að hafa hjartað á réttum stað og vera reiðubúinn að gagnast öðrum.

Ég veit ekki hvort við erum komin öllu lengra en pessir fornspekingar í pví að skilja sambandið milli eigin hagsmuna og almannahags. Við getum pó að minnsta kosti lært af peim að spyrja hvort pað sé gott fyrir einstakling að vera sjálfhverfur eða hvort pað endi í frekju sem eitri tilveru hans sjálfs. Pegar við veltum pví fyrir okkur hvort pað sé gott fyrir barn að læra petta eða hitt ættum við að minnsta kosti að hafa í huga að pað skiptir máli hvort um er að ræða sjálfhverfa hagsmuni barnsins eða hag pess af fullri pátttöku í mannlífinu.

Í rökræðu um hvað sé gott fyrir börn að læra skiptir máli hvort við hugsum um pau sem sjálfhverf eða ósérplægin og hvort við horfum á lífsbaráttuna sem samkeppni eða samstarf. Nemandi getur hugsað sem svo að pað sé öllum til góðs að sem flestir læri dönsku og efnafræði og pví sé best að temja sér áhuga og dugnað til að gera pað. Dað er líka mögulegt fyrir nemanda að reyna að komast hjá öllu sem ekki er beinlínis til hagsbóta fyrir hann sjálfan. Ef peir Platon og Aristóteles höfðu réttan skilning á hamingju manna og farsæld er pankagangur af fyrri gerðinni ekki einungis betri fyrir heildina heldur líka fyrir hvern og einn.

Munurinn á einstaklingshyggju og félagshyggju um menntun getur birst á marga vegu, meðal annars í pví hvernig við svörum börnum sem spyrja: Hvers vegna purfum við að ganga í skóla? Einstaklingshyggja býður upp á að segja að pað sé peim sjálfum til góðs, pau purfi menntun til að fá vinnu og afla tekna. Pótt einstaklingshyggja virðist um sumt andstæð forræðishyggju er töluverð forræðishyggja innbyggð í slíkt svar par sem svarandi lætur sem hann viti hvað er spyrjendum til góðs. Félagshyggja um menntun býður hins vegar upp á að segja börnum að við viljum að pau gangi í skóla vegna pess að pað sé okkur öllum til góðs að pau geti unnið gagnleg störf og alið eigin börn vel upp síðar á ævinni, tekið pátt í stjórnmálum og menningarlífi og leiðrétt okkur hin pegar við höfum rangt fyrir okkur. Á móti njóti bau góðs af pví að annað fólk sé menntað - ella liðu pau fyrir heimskulegar ákvarðanir og vandamál sem fylgja almennu menntunarleysi. Í pessu svari er raunar miklu minni forræðishyggja fólgin pví spyrjendum er boðið að vera pátttakendur í menntuðu samfélagi og leggja sitt af mörkum til að breyta pví.

\section{Vitsmunalegt lystarleysi}

Ímyndum okkur að til sé lystarlaust fólk. Ég er ekki að tala um fólk með sjúkdóminn lystarstol, heldur einfaldlega fólk sem finnst matur ekkert góður og langar ekkert meira í rétti sem ilma pannig að við hin fáum vatn í munninn heldur en bragðlausa blöndu af næringarefnum. Ef svona fólk er til pá finnst pví vönduð eldamennska að hætti sælkera vera hrein og klár tímasóun. 
Dað er væntanlega hægt að fá pað til að taka vítamín og lýsi ef pess parf en rök fyrir eiginlegri matargerðarlist tala ekki til pess.

Með hliðsjón af svona ímynduðum skorti á matarlyst getum við hugsað okkur vitsmunalegt lystarleysi. Dað er í pví fólgið að vera til í að læra pað sem parf til að fá vinnu og komast af en ekkert umfram pað. Dau sem eru haldin lystarleysi af pessu tagi eru laus við allan fróðleiksporsta. Dað er hægt að réttlæta sumt nám fyrir peim rétt eins og pað er hægt að réttlæta bætiefni fyrir manneskju sem skortir alla matarlyst. Hætt er samt við аð pað fari allt fyrir ofan garð og neðan ef reynt er að útmála fyrir peim hversu frábært er kynnast stjörnufræði, læra um samfélög fornaldar, pekkja jurtirnar í móanum, skilja hvernig hægt er að draga ferningsrót með hringfara og reglustiku eða kunna vísur og ljóð.

Svo má líka hugsa sér siðferðilegt og fagurfræðilegt lystarleysi sem er náskylt pví vitsmunalega. Раð fyrrnefnda er andstæða pess að hungra og pyrsta eftir réttlætinu eins og Jesús orðaði pað í Fjallræðunni (Biblían. Matteusarguðspjall, 5:6) og pað síðarnefnda felur í sér blindu á gildi lista og fegurðar.

Fólk sem sífellt langar að skilja mannlífið og náttúruna hefur litla pörf fyrir réttlæetingu á fögum eins og dönsku eða efnafræði. Ef gert er ráð fyrir að fólk hungri og pyrsti í pekkingu pá verður sennilega lítil andstæða milli áherslu á námsgreinar og áherslu á parfir nemenda. Hins vegar ef gert er rád fyrir að nemendur séu lystarlausir í peim skilningi að pá langi ekki í pekkingu, en séu aðeins til í að læra pað sem peir purfa til að komast af, pá er vandséð hvernig hægt er að réttlæta nema lítinn hluta af pví sem almennt er kennt í skólum með vísun í parfir einstaklinganna. Sé horft á parfir samfélagsins má hins vegar benda á að alls konar framfarir sem allir njóta góðs af eru óhugsandi án pess að til sé töluverður hópur af fróðleikspyrstu fólki. Ef til vill má líka benda á að sennilega fjari undan siðferði og par með öryggi og friði ef fáir hafa áhuga á bókmenntun, listum og pælingum um mannlífið. Útbreitt vitsmunalegt lystarleysi kann pví að vera slæmt fyrir heildina. Fyrir pau lystarlausu er pó líklega erfitt að sjá ástæðu til að læra neitt umfram pað sem „parf“ miðað við peirra fátæklegu sýn á mannlegar parfir.

Við getum skilið hagsmuni nemenda pröngum skilningi út frá fátæklegri sýn á hvað peir purfa og litið svo á að peir dafni ef peir halda heilsu og afla tekna. Ef vitsmunalegt lystarleysi bætist ofan á einstaklingshyggju um menntun er hætt við að stór hluti af öllum námsgreinum virðist tilgangslaus með öllu. Við getum líka litið svo á að pekkingarprá sé eftirsóknarverð og pörfum skólabarna verði ekki mætt nema pau eigi pess ríkulegan kost að leita pekkingar, skapa hugsjónir, próa menningarhefðir og taka pátt í rökræðu og nýsköpun.

Ef við göngum að lystarleysinu sem gefnu verður erfitt að sætta áherslu á parfir nemenda við faggreinastefnu af pví tagi sem mótað hefur starf barna- og unglingaskóla allt frá pví áður en skólaskylda var leidd í lög. Við purfum pó ekki að velja pennan kost. Við getum hugsað sem svo að pað sé börnum gott að læra að meta margs konar námsgreinar.

Dótt pær ferns konar menntastefnur sem nefndar voru geti stangast á pá purfa pær ekki að gera pað. Đær geta líka unnið saman. Svo virðist sem gildandi aðalnámskrár fyrir leikskóla, grunnskóla og framhaldsskóla geri rád fyrir að hægt sé að sætta pær og gera allt í senn að sinna hagsmunum einstaklinga, pjóna pörfum samfélagsins og kenna námsgreinar. Í ađalnámskrám allra pessara skólastiga segir að almenn menntun sé „hvort tveggja í senn einstaklingsmiðuð og samfélagsleg“ og að viðfangsefni skólastarfsins séu „sett fram í námssviðum, námsgreinum eða námsáföngum“ sem séu „hjálpartæki til að stuðla að merkingarbæru námi og ná markmiðum skólastarfsins“ (Mennta- og menningarmálaráðuneytið 2011, bls. 11 og 13, 2012, bls. 11 og 13, 2013, bls. 12 og 15).

Í aðalnámskrá grunnskóla er viðmiðunarstundaskrá með tillögu um hvað einstakar námsgreinar og greinaflokkar fái mikinn hluta kennslutímans. Par er til dæmis lagt til að stærðfræðin fái tæp 15\% og íslenskan rúm 18\% af kennslutímanum. Hefðbundin bókleg fög fá samtals um tvo priðju 
hluta tímans samkvæmt tillögu aðalnámskrár en ípróttir, listir, verkgreinar og val samtals um priðjung (Mennta- og menningarmálaráðuneytið, 2013). Рað er tæpast hægt að skilja petta öðru vísi en svo að pótt markmið grunnskólanna séu í senn einstaklingsmiðuð og samfélagsleg pá skuli unnið að peim með kennslu sem er að mestu í anda faggreinastefnu með áherslu á hefðbundnar námsgreinar.

\section{Til umhugsunar}

Skólar hafa mörg hlutverk: Ef vel tekst til kenna peir lestur og fleira sem parf til að afla sér pekkingar; fræða nemendur um mannlífið og náttúruna og kynna peim listir, ípróttir, tækni, vísindi og fræði; pjálfa nemendur í rökræðu og gagnrýninni hugsun og innræta peim vitsmunalegar og siðferðilegar dygðir eins og gætni í dómum, sanngirni og hjálpsemi; búa nemendur undir pátttöku í atvinnulífi; vekja áhuga á námi; eru öruggur staður fyrir börn til að vera á meðan foreldrar vinna; stuðla að jöfnuði og pví að nemendur með ólíkan bakgrunn kynnist.

a) Hafa skólar fleiri hlutverk en talin eru hér að ofan?

b) Hver (ef einhver) af pessum hlutverkum eru ópörf og hver (ef einhver) eru mikilvæg?

c) Eiga einhver hlutverk við á einu skólastigi öðrum fremur?

d) Tilheyrir hvert hlutverk einni eða fleiri af menntastefnunum sem nefndar voru í byrjun kaflans?

e) Er hægt að álykta af hlutverkum skóla hvað heppilegast sé að kenna?

f) Getum við leyft okkur að skylda barn til að læra eitthvað vegna pess að pað er gott fyrir aðra en barnið sjálft?

g) Er gott fyrir barn að læra aðeins námsefni sem pað sjálft hefur pörf fyrir? 


\section{Frelsi og námsgreinar}

Í fyrsta kafla bókar sinar Lýdraði og menntun (Democracy and Education) sem út kom árið 1916 segir bandaríski heimspekingurinn John Dewey (1976-1983, 9. bindi) að menntun sé samfélagi pað sem næring er lífveru. Hún viðhaldi lífi pess. Til að kunnátta, tækni, venjur, siðir, mál og menning lifi purfa börn að læra af peim sem eldri eru. Menntun alls almennings á sér pví miklu lengri sögu en skólar. Hér á landi lærðu börn til dæmis lestur, landbúnað og sjósókn, tóvinnu og prjónaskap, sögur og ljóð og margt fleira áður en farið var að senda pau í skóla.

Víða um heim eiga skólar sér líka sögu sem hófst löngu áđur en sett voru lög um skólaskyldu. Рað kemur pví ekki á óvart að til eru skrif um menntamál og menntastefnur frá pví í fornöld. Hér verður ekki reynt að rekja sögu menntaheimspekinnar heldur staldrað við tvær stefnur sem hafa töluverð áhrif á námskrár í okkar heimshluta enn í dag. Dessar stefnur eru upplýsingin og húmanisminn.

Í upphafi er samt rétt að nefna að allt frá pví í fornöld hafa margir tengt lærdóm við frelsi eða frjálsmannlegt líf. Fyrir um pað bil tveimur árpúsundum ræddu rómverskir spekingar á borð við Cicero (á fyrstu öld f. Kr.) og Seneca (á fyrstu öld e. Kr.) til dæmis um lærdóm sem hæfði frjálsum mönnum. Sá lærdómur sem peir höfðu mestar mætur á var vísindi, heimspeki, bókmenntir og listir sem próuðust á Grikklandi nokkrum öldum fyrr. Um slíkan lærdóm notuðu Rómverjar orðin artes liberales. Баð orðalag er pýtt sem frjálsar listir á íslensku og liberal arts á ensku. Nokkrum öldum seinna, pegar komið var fram á miðaldir, var víða talað um hinar sjö frjálsu listir sem æðri skólar kenndu. Đær voru málfræði, mælskulist, rökfræði, rúmfræði, talnafræði, tónlist og stjörnufræði. Á seinni tímum er orðalagið frjálsar listir ekki tengt pessum námsgreinum sérstaklega heldur er pað notað um breiða almenna menntun, einkum í bóklegum greinum eins og heimspeki, guðfræði, bókmenntum, sögu og félagsvísindum, stærðfræði og raunvísindum, sem færir nemendum skilning á menningu, náttúru og samfélagi (O’Hear og Sidwell, 2009). Enn pann dag í dag gera margir rád fyrir pví, eins gert var í fornöld, að slík menntun færi nemendum frelsi (Barrow, 2014; Hinchliffe, 2014).

Eins og nefnt var í síðasta kafla var skólaganga barna og unglinga víða orðin nokkuð almenn áður en skólaskyldu var komið á. Рað hvað kennt var mótaðist af hefðum og venjum ekki síður en af fyrirmælum stjórnvalda. Pessar hefðir og venjur gengu svo inn í skólakerfi sem rekin voru af stjórnvöldum og hafa sumar reynst býsna lífseigar. John White (2009), enski heimspekingurinn sem var nefndur í síðasta kafla, rekur pessar venjur allt aftur til sextándu aldar og tengir miðlun fróðleiks í skólum nútímans við áherslu kristinna hreintrúarmanna á gildi pess að alviska guðs endurspeglist 1 mannshuganum.

Rannsóknir sem gerðar hafa verið hér á landi benda til að staða hefðbundinna námsgreina sé sterk við íslenska grunn- og framhaldsskóla. Hafdís Ingvarsdóttir (2004) hefur til dæmis kannað skilning ensku- og raungreinakennara við framhaldsskóla á eigin starfi og komist að pví að hann ráðist að talsverðu leyti af námsgreininni sem peir kenna, peim pyki vænt um hana og sú væntumpykja móti starf peirra. Vísbendingar eru einnig um að faggreinasjónarmið hafi veruleg áhrif á störf grunnskólakennara. Í grein um sýn fimm grunnskólakennara á nám og kennslu í 
náttúruvísindum segja Meyvant Dórólfsson, Allyson Macdonald og Eggert Lárusson (2007) að peir vinni í anda faggreinastefnu. Sjálfur tók ég eitt sinn viðtöl við átján framhaldsskólakennara sem kenndu sögu, raungreinar og stærðfræði og par kom fram að peir töldu sig mennta nemendur og pjóna almennum námsmarkmiðum með pví einu að kenna námsgreinarnar sínar (Atli Harðarson, 2010a).

Námsgreinarnar sem lifðu af allt umrót síðustu aldar eru einkum lestur, skrift, stærðfræði, saga, landafræði, náttúrufræði, erlend tungumál, móðurmál og bókmenntir. Pað má líka nefna handavinnu og ípróttir og fleiri greinar sem kenndar eru í flestum skólum nútímans. Ég læt liggja milli hluta hvort rætur pessarar námskrár liggja í hreintrúarstefnu sextándu aldar, eins og White segir, eða enn dýpra í fortíðinni. Pegar pessi námskrárhefð var rökrædd og löguð að vaxandi skólakerfum og nýupptekinni skólaskyldu á seinni hluta nítjándu aldar og fyrstu áratugum peirrar tuttugustu voru átökin einkum milli talsmanna upplýsingarstefnunnar annars vegna og arftaka húmanismans hins vegar. Á nítjándu öld var síðarnefndi hópurinn nátengdur rómantísku stefnunni og kannski álitamál hvor merkimiðinn er réttari, rómantík eða húmanismi.

\section{Upplýsingin og húmanisminn}

Enski heimspekingurinn John Locke, sem uppi var á sautjándu öld, er oft talinn helsti brautryðjandi upplýsingarstefnunnar. Dessi stefna breiddist út á átjándu öld og hafði ómæld áhrif á menningu og stjórnmál í Evrópu og Norður-Ameríku, meðal annars byltingarnar sem gerðar voru undir aldarlok í Bandaríkjunum og Frakklandi. Meðal helstu hugsuða upplýsingarinnar á átjándu öld voru franski rithöfundurinn Voltaire og pýski heimspekingurinn Immanuel Kant.

Dað sem helst einkenndi upplýsingarmenn var trúin á mátt skynsemi og vísindalegrar hugsunar en tortryggni í garð trúarbragða, kennivalds og samfélagshátta sem studdust meira við venjur en skynsamleg rök. Menntastefna peirra lagði áherslu á að venjulegt fólk öðlaðist víðfeðma pekkingu og lærði að hugsa rökrétt og vísindalega. Ef slík menntun næði til porra fólks pá pyrfti enga yfirstétt til að hafa vit fyrir albýðunni, venjulegt fólk gæti sjálft stjórnað eigin lífi. Menntastefna Lockes og upplýsingarmanna sem á eftir honum komu var pannig nátengd hugsjónum um frelsi almennings. Upphaf pessarar menntastefnu má rekja til Hugleiðinga um menntamál eftir John Locke par sem hann gefur foreldrum rád um menntun sona sinna og lætur pess getið, í mjög stuttu máli, аð pau geti að miklu leyti líka gilt um dætur. Hann lauk ritun pessarar bókar árið 1693.

Locke lagði áherslu á að uppalendur kæmu fram við börn sem viti gædd, rökræddu við pau og kenndu peim að vera stolt af pví að vera skynsemisverur. Námsgreinarnar sem hann lagði til að börnum væru kenndar áttu meðal annars að pjálfa pau í að hugsa skynsamlega og leita sannleikans. Dessar námsgreinar voru: Lestur, skrift, talnareikningur, rúmfræði, bókfærsla, stíll og ritun á móðurmáli, franska, latína, náttúruvísindi, stjörnufræði, landafræði, saga, lög og hagnýtur fróðleikur um samfélagið, biblíusögur, siðfræði, teikning, garðyrkja og landbúnaður, smíði og dans. Einkum taldi hann ungu fólki gott að læra stærðfræði til pess að pjálfast í að hugsa skynsamlega: „Dví hygg ég hún skuli öllum kennd ef tími og tækifæri gefast, og pað til pess að gera pá að skynsemisverum fremur en til pess að gera pá að stærðfræðingum“ (Locke, 1993b, \$6).

Ef við skiptum latínu út fyrir ensku, sem er helsta alpjóðamálið nú um stundir, er pessi meira en fjögurra alda gamli námsgreinalisti sláandi líkur upptalningu á helstu kennslugreinum í barna- og unglingaskólum nútímans. Meðal pess sem vantar inn í hann eru bókmenntir, listir og ípróttir. Hjá Locke var önnur líkamsrækt en dans ekki hluti af námskránni pótt hann segði að líkamleg áreynsla væri nauðsynleg og hefði góð áhrif á heilsu barna. Hann var heldur mótfallinn hefðbundinni ípróttakennslu fyrir syni yfirstéttarinnar par sem áherslan var á skylmingar og fleiri ípróttir sem tengdust hernaði. Locke áleit pessa hefð ala á ofbeldi og vondum siðum eins og hólmgöngum. Teikning sem Locke mælti með var leikni í að skrá upplýsingar með myndum og pví meira í æett við tækniteikningu en myndlist. Skáldskap og listum sleppti hann líklega vegna pess að námskrá hans var uppreisn gegn skólum húmanista par sem ofuráhersla var lögð 
á fornar bókmenntir auk mælskulistar. Locke gekk sjálfur í slíkan skóla par sem ríkti strangur agi og nemendum var refsað ef peim tókst ekki að læra námsefnið utan að (Woolhouse, 2007). Hann líkti meðferðinni á skólafélögum sínum við prælahald í fornöld og sagði að „,prælslegur agi mundi ala af sér prælslegt lundarfar“ (Locke, 1989, \$50). Menntastefna upplýsingarinnar var pví að nokkru leyti mótuð af andstöðu gegn húmanismanum.

Húmanisminn er stefna í skólamálum sem mótaðist á fimmtándu og sextándu öld. Á íslensku er pessi stefna stundum kölluð fornmenntastefna. Talsmenn hennar lögðu áherslu á að nemendur kynntust pví besta úr bókmenntum heimsins, einkum fornbókmenntum á grísku og latínu.

Til að skýra í stuttu máli muninn á menntastefnu húmanista og upplýsingarmanna má segja, með nokkurri einföldun, að peir fyrrnefndu hafi lagt áherslu á pað háleita og kynni af listum og menningu en peir síðarnefndu á pað hagnýta og víðfeðma pekkingu á náttúru og samfélagi.

Mestalla átjándu öld var stefna upplýsingarmanna í sókn og húmanistar í vörn við skóla í norðvestanverðri Evrópu og Norður-Ameríku. Degar nítjánda öldin gekk í garð snerist pó taflið og rómantískir hugsuðir endurvöktu áherslu húmanista á menntagildi bókmennta og lista. Mest áhrif í pessa veru hafði býska skáldið Friedrich Schiller sem birti áhrifamiklar tímaritsgreinar árið 1785 um fagurfræðilegt uppeldi mannsins. Par heldur hann pví fram að til að menntun stuðli að alhliða proska purfi hún að innihalda kynni af bókmenntum og listum og sagði að til að „leggja rækt við mennskuna í sínu eigin eðli“ pyrfti að hlúa að tilfinningaproska ekki síður en skynsemi og rökhugsun (Schiller, 2006, bls. 92). Schiller og eftirmenn hans á nítjándu öld reyndu pó ekki að endurvekja námskrána sem Locke andmælti óbreytta. Deir töldu til dæmis flestir að bókmenntir á módurmáli nemenda væru mikilvægar ekki síður en fornrit á latínu og grísku. Dessi áhersla náði hingað norður til Íslands pegar sett voru lög um kennslu til undirbúnings háskólanámi í ríki Danakonungs um 1850 par sem kveđið var á um að til stúdentsprófs skyldi aðaláhersla lögð á pekkingu á menningu fornaldar og bókmenntir á móðurmálinu (Kristinn Ármannsson o.fl., 1975).

Mestan hluta nítjándu aldar einkenndist umræða um skólamál af átökum milli upplýsingarmanna sem vildu einkum miðla gagnlegri vísindalegri pekkingu og húmanista sem lögðu áherslu á listir og menningu. Faggreinamiðaðar námskrár sem opinberu skólakerfin tóku í arf frá eldri skólum eru málamiðlanir milli pessara ólíku hugmynda um menntun og námskrá. Greinarnar sem Locke mælti með fengu víðast hvar mikinn hluta kennslutímans en pað var komið til móts við kröfur húmanista með pví að bæta við sögum og ljóðum, söng og myndlist. Móðurmálskennsla við íslenska skóla inniheldur til dæmis bæði stíl og ritun á móðurmáli í anda Lockes og lestur á Íslendingasögum og fleiri bókmenntaverkum í anda Schillers og húmanistanna.

Í ljósi pessarar sögu getum við séð að faggreinastefnan sem nefnd var í fyrsta kafla er í raun blanda úr tveimur stefnum sem eru ólíkar og jafnvel andstæðar (Atli Harðarson, 2011). Flestir sem kenna sig við frjálsar listir í samtímanum sækja í báđar pessar stefnur.

\section{Framstefnuskólinn og menntun til frelsis}

Degar skólaskylda var komin á víðast hvar í okkar heimshluta undir lok nítjándu aldar létu margir sig dreyma um að skólinn færði börnum ekki einungis kunnáttu og pekkingu heldur líka betra og hamingjuríkara líf. Öflugasta hreyfingin í skólamálum sem varð til á pessum tíma er gjarna kennd við framstefnu (e. progressivism) og sá hugsuður sem hafði mest áhrif á hana var Dewey sem nefndur var í upphafi pessa kafla.

Framstefnumenn tóku undir andmæli Lockes gegn utanbókarlærdómi, hörðum aga og refsingum. Margir peirra tóku líka undir með Schiller og húmanistunum sem sögðu að vísindaleg pekking ein og sér dygði ekki til að stuðla að alhliða proska. Prátt fyrir gagnrýna afstöðu til peirra tveggja hefða sem hér hefur verið fjallað um var framstefnan nátengd peim báðum, einkum 
upplýsingarstefnunni. Sumir hafa jafnvel gengið svo langt að telja Locke einn af helstu upphafsmönnum framstefnunnar (Howlett, 2013) og aðrir hafa lýst Dewey sem upplýsingarmanni (Putnam, 2004).

Áherslum framstefnumanna á verkefnadrifið nám og tengsl við náttúruna og veruleikann utan skólastofunnar hefur oft verið stillt upp sem andstæðu við hefðbundnar námsgreinar á borð við sögu eða náttúrufræði. Pótt sumir talsmenn framstefnu vildu úthýsa námsgreinum úr skólunum var enginn einhugur um pað peirra á meðal og raunar lögðu peir flestir áherslu á mikilvægi greina af pví tagi sem Locke vildi kenna börnum (Howlett, 2013). Dewey var til dæmis afar gagnrýninn á andóf gegn faggreinum sem honum pótti ganga út ́ öfgar. Fyrir vikið hafa sumir lýst skólastefnu hans sem fremur hefðbundinni og jafnvel gamaldags (Jackson, 1990; Westbrook, 1991; Boisvert, 1998; Ólafur Páll Jónsson, 2010). Hann lagði áherslu á að börn kynntust vísindalegri hugsun og lærðu að láta skynsamleg rök móta afstöðu sína og pvertók fyrir að skólar og kennarar ættu að velja milli pess að hafa barnið í brennidepli og að kenna námsgreinar. Detta fór saman að áliti Deweys (Atli Harðarson, 2016; Kotzee, 2018).

Í ljósi pess sem hér hefur verið sagt er ef til vill ekki svo undarlegt að faggreinarnar hafi haldið velli prátt fyrir allt umrót síðustu aldar. Dær áttu, og eiga enn, verulegan stuðning meðal umbótamanna í menntamálum. Martha Nussbaum $(1998,2010)$, sem er með pekktari heimspekingum samtímans, hefur til dæmis skrifað bækur um að menntun í anda húmanisma sé ein af forsendum lýðræðislegra samfélagshátta. Hún boðar samt ekkert afturhvarf til fortíðar pví hún leggur áherslu á að nú purfi að miðla fjölbreytilegri bókmennta- og menningararfi og tala til sundurleitari nemendahóps. Eins og fjallað verður um í næsta kafla eiga sjónarmið í anda upplýsingar sér líka enn öfluga talsmenn meðal fræðimanna sem fjalla um menntavísindi.

Stundum er faggreinastefnu í menntamálum lýst svo að hún feli í sér pá skoðun að námsgreinarnar hafi sitt eigið gildi. Detta má til sanns vegar færa enda innifela menningarhefðir og fræðigreinar gildi og tilgang sem menn tileinka sér aðeins innan peirra. Bæði Locke og Schiller litu samt svo á að námsgreinar stuðluðu að betra lífi. Schiller talaði um alhliða proska. Locke taldi námskrá sína stuðla að góðu siðferði og að með pví að venja börn á skynsamlega hugsun og rökræður væri peim kennt að breyta af yfirvegun og losa hug sinn úr fjötrum óskynsamlegra duttlunga (Atli Harðarson, 2019b). Löngu seinna orðaði Dewey svipaða hugsun í bókinni Reynsla og menntun par sem hann sagði:

Hið háleita markmið skólastarfs er að skapa hæfni til sjálfstjórnar. En pað eitt að fjarlægja ytra taumhald er engin trygging fyrir pví að pað markmið náist [...] Раð kann að vera tap frekar en ávinningur að losna undan stjórn annarrar manneskju til pess eins að komast аð raun um að hegðun manns ræðst af dyntum og duttlungum augnabliksins, p.e. hún er ofurseld hvötum og hneigðum sem dómgreind og skynsemi hafa ekki átt neinn pátt 1 a a móta. Degar hegðun einstaklingsins er stjórnað með pessum hætti lifir hann aðeins í ímynduðu frelsi. Í raun og veru er honum stjórnað af öflum sem hann hefur alls ekki á valdi sínu. (Dewey, 2000, bls. 74-75).

Eins og Locke og upplýsingarmenn átjándu aldar taldi Dewey að pekking á vísindum færði mönnum frelsi, tök á tilverunni og möguleika til að stjórna eigin lífi enda lét hann sér afar annt um lýðræði og frelsi almennings. Dewey var ekki aðeins umhugað um að einstaklingar gætu látið dómgreind og skynsemi móta eigin breytni heldur líka að allur almenningur hefði menntun til að stjórna eigin vinnu og nærsamfélagi. Honum var einkum umhugað um vinnustaðalýðræði sem pýddi meðal annars að kennarar hefðu eitthvað um pað að segja hvernig skólum væri stjórnað og verkafólk um vinnufyrirkomulag og starfshætti í verksmiðjum (Atli Harðarson, 2018b). Um pessa lýðræðishugsjón Deweys verður fjallað ögn nánar í tólfta kafla. 


\section{Til umhugsunar}

Málamiðlun upplýsingar og húmanisma sem hér hefur verið sagt frá leiddi til pess að bókmenntum og listum var bætt inn í námskrá sem var að miklu leyti í anda Lockes. Listir hafa pó fengið fremur lítið rúm í flestum skólum og á framhaldsskólastigi hér á landi hefur hlutfall peirra af kennslutíma jafnvel farið minnkandi. Fyrst eftir að Lærða skólanum var breytt í Hinn almenna menntaskóla í Reykjavík árið 1904 voru söngur, teikning og smíði til dæmis skyldugreinar til stúdentsprófs en nú er hægt að ljúka stúdentsprófi án pess að læra slíkar greinar.

Önnur námsgrein sem einnig hefur farið heldur halloka er kristinfræði. Í fjölmenningarlegu samfélagi nútímans mundi fræðsla um trúarbrögð og trúarlegar hefðir pó væntanlega fjalla um fleira en kristni. ${ }^{1.2}$ Ef bað er rétt sem pýski félagsfræðingurinn Ulrich Beck (2010) segir í bók sinni um trúarbrögð í byrjun tuttugustu og fyrstu aldar, að fólk sem vex upp í trúarlegu tómarúmi sé líklegra til að trúa hverju sem er heldur en að trúa ekki á neitt, pá kann pessi eyða í námskrám nútímans að vera áhyggjuefni.

Kannski purfa börn og unglingar að kynnast ritum á borð við Biblíuna, Kóraninn, Bhagavad Gita, Dhammapada og Bókina um veginn. Kannski eiga pau sem hafa tekið pátt í rökræðu um merkingu slíkra rita betri kosti á að mynda sér skynsamlegar skoðanir um eilífðarmálin og eru pá kannski síður móttækileg fyrir öfgum og firrum. Vera má að almenn pekking á trúarbrögðum sé líka ein af forsendum pess að fjölmenning okkar verði að sameiginlegri víðsýni fremur en margs konar einsýni.

a) Hvað parf fólk að læra til að geta stjórnað eigin lífi?

b) Hvaða námsgreinar vantar í skóla og hvaða námsgreinum er ofaukið?

c) Darf listinn yfir námsgreinar í skólum að breytast vegna pess að nemendur hafa margvíslegan menningarlegan bakgrunn og samfélagið er fjölmenningarlegra en fyrr á árum? Darf hann að breytast af öðrum ástæðum, til dæmis vegna nýrrar tækni eða nýrra vandamála?

d) Hvenær eiga börn að byrja að læra námsgreinar eins og til dæmis stærðfræði, ensku og náttúrufræði? Eiga pær heima í leikskólum? Hvað með yngsta stig grunnskóla?

e) Hve stór hluti af skólatímanum í leikskólum, grunnskólum og framhaldsskólum á að fara í kennslu námsgreina og hve stór hluti í annars konar viðfangsefni? 


\section{Jöfnuður og námsgreinar}

Í síðasta kafla var meðal annars ræett um hvernig hugsjónir upplýsingarmanna og húmanista á átjándu og nítjándu öld og talsmanna framstefnu í byrjun tuttugustu aldar tengdust hugmyndum um frelsi og sjálfstjórn og voru pannig á vissan hátt framhald af mun eldri menntastefnu sem kennd er við frjálsar listir. Dessar áherslur á menntun til frelsis voru nátengdar kröfum um aukinn jöfnuð og jafnrétti. Tengsl aukinnar skólagöngu við sókn til meira jafnréttis eru pó samt ekki svo einföld að petta tvennt haldist ævinlega í hendur og styðji hvort annað. Dað flækir pau líka að uppi hafa verið æði ólíkar hugmyndir um með hvaða hætti allir menn eru jafningjar. Dýðir jöfnuður að allir skuli hafa sama rétt eða njóta sömu virðingar eða að öllum skuli búin svipuð kjör eða felur hann í sér blöndu af pessu öllu saman?

Raunar má líta á stóran hluta af stjórnmálaheimspeki upplýsingarmanna sem leit að svari við spurningum um hvernig samfélag manna geti orðið samfélag jafningja. John Locke, Immanuel Kant, höfundar bandarísku stjórnarskrárinnar, frönsku byltingarmennirnir, John Stuart Mill, Karl Marx og John Dewey svöruðu pessum spurningum á ólíkan hátt en áttu pað pó allir sameiginlegt að hafna eldri hugmyndum um að mannkynið myndaði stigveldi pannig að sumir væru öðrum æðri ${ }^{1.3}$ Svipaða sögu er að segja um stjórnmálaheimspeki síðustu áratuga par sem helstu kenningar um réttlæti veita, eins og indverski hagfræðingurinn og siðfræðingurinn Amartya Sen (2011) segir, ólík svör við pví með hvaða hætti menn eru jafningjar.

Locke svaraði spurningunni um í hverju jöfnuður manna væri fólginn með kenningu um náttúruleg réttindi sem væru söm fyrir alla enda „ekkert augljósara en pað að skepnur af sömu tegund og tign, jafnbornar til allra náttúrlegra gæða og sömu sálargáfum gæddar, skuli einnig jafnar sín í milli pannig að engin peirra sé annarri undirgefin“" (Locke, 1993a, bls. 46). Detta svar Lockes hefur gengið í endurnýjun lífdaga á síðustu áratugum með vaxandi áherslu á mannréttindi sem allir menn skuli njóta til jafns (Atli Harðarson, 2015). Aðrir hugsuðir eins og Marx og fylgismenn hans hafa lagt meiri áherslu á að skýra hvernig mismunun og ójöfnuður eru afsprengi valdbeitingar og viðhaldið með blekkingum.

Frá upphafi skólaskyldu og opinberra menntakerfa hafa hugsjónamenn af ýmsu tagi bundið vonir við að almenn menntun stuðlaði að jöfnuði enda átti skólaskyldan að verða til pess að börn af öllum stéttum fengju svipað veganesti fyrir lífið. Allan pennan tíma hafa menn samt staðið frammi fyrir peirri staðreynd að menntakerfi viðhalda og endurskapa stéttaskiptingu par sem börn yfirstéttar hafa ýmislegt forskot í skólakerfinu og eiga að jafnaði greiðastan aðgang að námi sem tryggir völd og tekjur.

Gengi nemenda í skólum veltur vissulega að nokkru leyti á gáfum peirra, dugnaði og mannkostum. Dað er pó samt blekking að halda að ekkert annað ráđi pví hvernig einstaklingum vegnar. Í bók frá 2010 fjallar William Deresiewicz um inntöku í bandaríska háskóla og segir meðal annars að til að komast inn í virtustu skólana purfi ungmenni aðstoð foreldra og í flestum tilvikum talsverðan prýsting frá peim. Detta segir hann leiða til pess að eftirsóttustu skólarnir séu skólar ríka fólksins og peir séu pað í vaxandi mæli: „Árið 1985 komu 45\% nemenda í peim 250 háskólum sem vísuðu flestum frá úr fjölskyldum í efsta fjórðungi í tekjudreifingunni. Petta hlutfall var 55\% árið 2000 
og 67\% árið 2006“ (Deresiewicz, 2014, bls. 205). Deresiewicz, sem var prófessor við enskudeild Yale-háskóla til 2008, segir ennfremur að inntaka í virtustu háskólana sé peningapvottavél valdakerfis sem hann kallar „,meritocracy“ pví pað lætur heita að völdum sé skipt eftir verðleikum fólks pannig að peir hæfustu og duglegustu fái mest. Eins og peningapvottur glæpamanna felst 1 pví að setja upp eitthvað sem virðist heiðarleg starfsemi og láta líta svo út að illa fengið fé sé arður af henni, eins lætur „,pvotturinn“ sem Deresiewicz ræðir um líta svo út að hæfileikar og dugnaður, en ekki ríkidæmi fjölskyldunnar, færi ungu fólki í hendur prófskírteini sem eru aðgöngumiðar að völdum og virðingu. Hluti af blekkingunni, segir hann, er að fólk trúir pví að nemendur úr öllum stéttum komist inn vegna hæfileika í ípróttum pví að tvær af peim ípróttum sem mest eru metnar við inntöku í skólana, fótbolti og körfubolti, eru iðkaðar af börnum alpýðunnar. Deir sem komast inn vegna afreka í greinum sem yfirstéttin situr nær ein að eru pó samt fleiri. Meðal pessara greina eru til dæmis skíðastökk og siglingar. Hann bætir pví við að petta veldi hinna „hæfustu“ sé vissulega orðið fjölmenningarlegt og í anda jafnréttis milli kynjanna en völdin gangi samt að erfðum og lítt sé hirt um að rétta pann halla sem mestu skiptir, nefnilega stéttamun.

Jöfnuður og jafnrétti í skólum hefur oft verið tengt vali á kennslugreinum. Á nítjándu öld, meðan fjöldi hvítra menntamanna trúði pví að fólk af evrópskum uppruna hefði vitsmunalega yfirburði yfir fólk frá öđrum heimsálfum, höfðu sumir peirra hugmyndir í pá veru að peirra eigin börn ættu að læra bóklegar greinar en börn af öðrum kynpáttum skyldu nema handverk og vinnubrögð (Gould, 1981/2006).

Einn af peim sem andmæltu hugmyndum um ólíka námskrá fyrir ólíkar stéttir og kynpætti pegar skólakerfi nútímans var enn í deiglunni var félagsfræðingurinn og sagnfræðingurinn William Edward Burghardt Du Bois. Hann var fyrsti bandaríski blökkumaðurinn til að ljúka doktorsprófi og með skeleggustu talsmönnum jafnréttis svartra og hvítra í byrjun síðustu aldar. Hann var stoltur af menningu síns fólks enda voru sögur og söngvar Bandaríkjamanna af afrískum uppruna merkileg nýsköpun í menningu og listum. Du Bois (2015) andmælti málflutningi peirra sem töldu að börn svartra ættu að fá hagnýta menntun fremur en fræðilega og sagði að menntun sem hefði háleit markmið og snerist um menningu og siðferði fremur en eintómt brauðstrit ætti ekki að vera séreign hvíta mannsins.

Síðan Du Bois skrifaði um menntamál hafa fjölmargir aðrir talsmenn frjálsra lista tekið í sama streng og varað við hugmyndum um að fræðilegt bóknám sé fyrir útvalda en aðrir eigi að láta sér duga að læra gagnleg störf (Entwistle, 1979; Bailey, 1984/2010; Gibboney, 1994; Furedi, 2009). Á móti má segja að ef börn sem hafa ónógan undirbúning eru sett í nám sem pau ráđa illa við pá eigi pau litla möguleika og verði ef til vill betur sett fái pau að gera eitthvað annað í skólanum en að dragast aftur úr í bóklegum greinum. Sem svar við pessu má svo benda á að nær sé að haga kennslunni pannig að hún gagnist öllum og ungt fólk nái valdi á námsgreinunum prátt fyrir misjafnt veganesti að heiman. Flestir sem hugsa á svipuðum nótum og Du Bois gera ráð fyrir að nemendur af ólíku pjóðerni og ólíkum stéttum geti lært og vara við pví að kennarar eða skólar ákveði fyrir fram að einhver viðfangsefni eða fög séu of erfið eða krefjandi fyrir suma hópa.

\section{Að nemandinn verði jafningi kennarans}

Rússneski skáldsagnahöfundurinn Leo Tolstoj starfrækti barnaskóla á óđali sínu á árunum kringum 1860. Dar kenndi hann sjálfur börnum bænda og kom af stað hreyfingu í Rússlandi sem beitti sér fyrir menntun alpýðu. Dessi hreyfing pótti róttæk og mæltist illa fyrir hjá yfirvöldum sem á endanum neyddu Tolstoj til að loka skólanum. Tolstoj ritaði líka um menntamál og mótaði sína eigin menntastefnu. Kjarni hennar var að menntun miðaði að pví að nemandinn yrði jafningi kennarans (Moulin, 2014).

Ef við sampykkjum jafnaðarhugsjón Tolstojs pá hljótum við að gera ráð fyrir að sá sem ákveður hvað eigi að kenna og hvers vegna ætli sér jafnframt að kenna nemendum pannig að peir geti 
skilið pessar ákvarðanir, gagnrýnt pær og endurbætt. Að öðrum kosti verða peir vitsmunalegir undirsátar peirra sem stjórna skólunum og ákveða námskrána. Af pessu leiðir að ef pað parf pekkingu í vísindum eða fræðum til að ákvarða námskrána pá ætti kennslan að gera pá sömu pekkingu aðgengilega fyrir nemendur.

Hugsum okkur að yfirvöld menntamála setji skólakerfinu markmið. Slík markmið gætu til dæmis verið hagvöxtur og aukin efnaleg velsæld, heilbrigt líf, jafnrétti og lýðræði eða lífshættir sem stuðla að sjálfbærri próun. Hugsum okkur líka að val á námsefni og kennsluhættir ráđist af pessum markmiðum. Dæmi valið af handahófi væri ef til vill að kenna fólki að rækta matjurtir í pví skyni að minnka vistspor pess. Sú ákvörðun væri rökstudd með vísun í pekkingu úr ýmsum greinum vísinda. Ef við tökum Tolstoj alvarlega ættum við að fara fram á að nemendur fengju að læra pessi vísindi svo peir gætu sjálfir vegið og metið ákvörðun yfirvalda. Svipaða sögu má segja um flest almenn markmið skóla. Dau styðjast við pekkingu sem verður mönnum ekki vel aðgengileg nema peir venjist við pælingar, fræði og vísindalega hugsun. Jafnvel markmið eins og aukið jafnrétti, sem hægt er að skilja að nokkru marki út frá hversdagslegi reynslu, tengist flóknum fræðum um leið og tekið er að rökræða pað (Atli Harðarson, 2013). Detta pýðir ekki að hver einasti maður purfi langskólamenntun í mörgum vísindagreinum. Рað er breitt bil milli pess að sleppa pví alveg að kenna greinar par sem reynir á rökvísi, gagnrýna hugsun og djúpan skilning á kenningum og aðferðum og að láta ungt fólk verja hverri vökustund í slíkan lærdóm. Jafnréttissinnar geta pó tæpast sett markið lægra en að gefa öllum kost á að taka pátt í rökræðu, meðal annars um hvað er pess virði að læra.

\section{Máttug pekking}

Á seinni hluta síðustu aldar rannsökuðu allmargir félagsfræðingar tengsl stéttarlegs uppruna nemenda við námsárangur. Deirra pekktastur er Bretinn Basil Bernstein (Gestur Guðmundsson, 2008). Í ritum sem komu út milli 1960 og 1980 benti hann meðal annars á að til pess að miðla pekkingu til barna úr ólíkum stéttum pyrfti að orða reglur og viðmið skólans á máli sem pau öll skildu. Hann benti líka á að allir menningarheimar ættu sér eigið málsnið og innvígðir gætu miðlað miklum upplýsingum í sinn hóp með knöppum skilaboðum og hálfkveðnum vísum. Detta á við um flest áhugamál fólks, til dæmis ípróttagreinar eins og knattspyrnu. Eigi svo að skýra samræðuna fyrir utanaðkomandi parf lengra mál. Бað sama gildir um námsgreinar eins og til dæmis stærðfræði eða sagnfræði. Til að leiða nemendur inn í heim peirra parf, að minnsta kosti fyrst í stað, útskýringar sem eru á máli nemendanna, ekki á máli greinarinnar.

Mál stærðfræðinnar er væntanlega jafn framandi flestum börnum hvort sem foreldrar peirra eru ríkir eða fátækir. Mál skólans sem er notað til að kenna mál stærðfræðinnar og fleiri greina kann pó að vera mislíkt hversdagsmáli barnanna eftir pví hvaðan pau koma. Með pví að beina athyglinni að talsmáta skólans fremur en námsgreinanna sjálfra benti Bernstein á að misjafnt námsgengi barna eftir stétt og stöðu foreldranna kynni að skýrast af öðru en pví að námsgreinarnar sjálfar væru óaðgengilegri sumum stéttum en öðrum (Moore, 2013).

Annar enskur félagsfræðingur, Michael Young, sem lærði af Bernstein og vann með honum, hefur haldið áfram að rannsaka hvernig talsmáti og starfshættir skólans hafa áhrifá misjafnt gengi nemenda eftir stétt og stöðu. Young $(2008,2009,2010$ a, 2010b, 2011) er í sama liði og Du Bois að pví leyti að hann varar við pví að koma til móts við parfir eða hugðarefni pjóðfélagshópa sem standa höllum fæti með pví að slá af kröfum um að skólar kenni námsgreinar sem færa nemendum skilning á heiminum. Í umfjöllun um petta efni notar hann hugtakið máttug pekking (e. powerful knowledge) og segir að slík pekking geri fólki kleift að útskýra, sjá fyrir og hefja sig yfir sínar eigin aðstæður og öðlast víðari sjóndeildarhring (Young, 2009).

Young dregur pó ekki fjöður yfir að margt hefðbundið námsefni beri með sér uppruna úr efri stéttum samfélagsins en bendir á að pekking á peim gefi mönnum engu að síður mátt til 
að afla nýrrar vitneskju og hefja sig yfir stéttbundin takmörk sín. Hvað petta varðar er Young arftaki upplýsingarmanna sem töldu vísindalega pekkingu færa mönnum skilning á pví hvernig heimurinn er og par með frelsi og stjórn á eigin lífi. Hann heggur jafnt á báđar hendur par sem hann berst í senn við talsmenn afstæðishyggju og pá sem segja að skólakerfið eigi aðeins að pjóna atvinnulífinu. Deir fyrrnefndu, sem sumir kenna sig við póstmódernisma, hafna pví að vísindaleg pekking sé neitt betri eða réttari en aðrar skoðanir og halda pví jafnvel fram að hún sé aðeins góð og gild á mælikvarða peirra sem mest hafa völdin. Deir síðarnefndu láta eins og pað sé óparfi að færa nemendum skilning á veruleikanum, pað dugi að gera pá að góðum starfsmönnum. Young segir að pessar tvær fylkingar hafi í raun tekið höndum saman, pótt andstæðar virðist, og báðar vinni gegn pví að skólar mennti nemendur sína.

Young bendir líka á að flótti frá námsgreinum sem veita fólki máttuga pekkingu sé líklegur til að auka stéttaskiptingu pví væntanlega verði hann meiri í skólum sem börn albýðu sækja en í skólum sem mennta börn yfirstéttarinnar. Útkoman úr pví verði að fleira og fleira alpýðufólk hafi í raun minni pekkingu og par með minni mátt prátt fyrir hærri prófgráđur (Young, 2008).

\section{Til umhugsunar}

Locke rökstuddi að menn skyldu njóta sömu réttinda með vísun til pess að peir væru sömu sálargáfum gæddir. Aðrir hugsuðir sem hér hefur verið vísað til virðast gera ráð fyrir að allir nemendur geti lært allar námsgreinar skóla. Dað er umhugsunarefni hvort pessir höfundar horfa fram hjá margbreytileika mannlífsins. Sumir eru ef til fæddir svo laglausir að peir geti aldrei lært og syngja og aðrir með skerðingu sem útilokar að peir læri til dæmis algebru eða erlend tungumál.

a) Geta skólar lagt áherslu á frjálsar listir og djúpan skilning á vísindum og fræðum og jafnframt boðið nám við allra hæfi?

b) Eru einhverjar námsgreinar sem eiga mismikið erindi við börn eftir stétt peirra, uppruna eða pjóðerni?

c) Á pað sem Deresiewicz segir um peningapvottavél valdakerfisins við um einhverja hluta af íslenska skólakerfinu?

d) Er einhver gerð af pekkingarleysi eða vankunnáttu sem gerir fólk að leiksoppum annarra eða kemur í veg fyrir jöfnuð?

Dótt við tökum undir með Young og teljum að máttug pekking eigi erindi við alla getum við haft ýmsar skoðanir um hve lengi allir nemendur skuli læra sömu fög. Við getum mögulega álitið að til séu viðfangsefni sem færa fólki skilning á veröldinni en henta aðeins hluta nemendahópsins án pess að telja að hinir eigi að fara á mis við djúpar pælingar. Ekkert útilokar að sumir unglingar læri til dæmis heimspeki og bókmenntir meðan aðrir sökkva sér ofan í stærðfræði og eðlisfræði.

e) Hvað er heppilegt að skyldunámsgreinar sem allir purfa að læra fái stóran hluta skólatímans? Gilda sams konar svör um petta efni fyrir leikskóla, öll stig grunnskóla og framhaldsskóla?

f) Hvað með háskóla? Er eitthvað sem allir háskólanemar ættu að læra?

g) Er hægt að andmæla stéttskiptu skólakerfi á svipuðum forsendum og Du Bois og Young án pess að setja verklegar greinar, eins og til dæmis iðnnám í framhaldsskólum, skör neðar en bóklegar greinar? 


\section{Parfir atvinnulífsins}

Í gildandi aðalnámskrám fyrir leik-, grunn- og framhaldsskóla segir um almenna menntun að hún stuðli ,á hverjum tíma að aukinni hæfni einstaklingsins til að takast á við áskoranir daglegs lífs" (Mennta- og menningarmálaráđuneytið, 2011, bls. 13, 2012, bls. 13, 2013, bls. 15). Detta bendir til að höfundar námskrárinnar líti svo á að menntun sé einkum hagnýt. Sambærilegt orðalag hefur verið á kreiki í plöggum um skólamál býsna lengi. Guðmundur Finnbogason, sem átti manna mestan pátt 1 a a móta stefnu íslenskra barnaskóla um pað leyti sem skólaskylda var tekin upp í byrjun síðustu aldar, segir til dæmis í bók sinni Lýdmenntun sem kom út árið 1903 að menntun hvers manns verði ,að metast eftir pví hve hæfur hann er til að lifa og starfa í mannlegu félagi“" (Guðmundur Finnbogason, 1903/1994, bls. 33). Guðmundur hélt pví pó alls ekki fram аð menntun væri til pess eins að bæta efnalega afkomu fólks. Hann var víðsýnni en svo og pað sama má segja um flesta frumkvöðla í skólamálum í upphafi síðustu aldar. Magnús Helgason, fyrsti skólastjóri Kennaraskólans, sagði til dæmis í bók um kennslufræði sem kom út árið 1919:

En taki nú hugurinn pá stefnu, að meta alla hluti eftir gagnsmunum, til arðs og aura, pá verða slík hyggindi til að deyfa tilfinningarnar, gera hjartað hart og kalt. Pau veita lífinu hvorki fegurð né unað. Skynsemin parf einnig að láta til sín taka og beina huganum að pví, sem er fagurt, satt og gott. (Magnús Helgason, 1919, bls. 81).

Degar Guðmundur Finnbogason og Magnús Helgason mótuðu skólastefnu síns tíma var enn haft fyrir satt að bókvitið yrði ekki í askana látið. Á pessum tíma var stór hluti langskólagenginna manna prestar sem áttu fremur að hirða um himneska fjársjóði en efnahagsleg gæði og atvinnulífið purfti kannski minna á menntamönnum að halda en síðar varð. Nú hefur petta snúist við og stór hluti af umræðu um skólagöngu umfram skyldunám gerir bæði ráð fyrir pví að hún stuðli аð bættum efnahag og að nemendur sæki skóla einkum til að bæta hæfni sína til að vinna sér inn peninga. Einnig heyrist oft sagt að nú sé tilveran flóknari en áður og pess vegna engin leið að komast af án mikillar skólagöngu. Veruleikinn er samt sá að stór hluti starfa sem losnar krefst lítillar kunnáttu svo mikill hluti fólks hlýtur að vera í vinnu sem er vel hægt að sinna án pess að hafa langa skólagöngu. Pað er líka blákaldur veruleiki að fólk parf minna og minna á pekkingu að halda til að komast af í daglegu lífi pótt pað verði ef til vill meira og meira háð pví að ýmisleg pekking sé til innan samfélagsins. Í gamla daga purfti flest fólk að kunna sjálft að breyta ull í fat og mjólk í mat. Nú er hægt að vera pokkalega til fara og éta fylli sína pó maður sé heimskur og fákunnandi. Við getum fengið mat og föt pótt lítill hluti mannafla á vinnumarkaði kunni að skapa pessi gæði. Við getum líka notað sjálfvirkar vélar og alls konar tækni án pess að kunna neitt í verkfræði eða forritun.

Рað er eitthvað mótsagnakennt við pennan veruleika samtímans par sem flestir virðast trúa pví að meiri skólaganga haldist í hendur við betri efnaleg kjör. Ef pað væri svo einfalt að lengri skólaganga gerði menn færari um að fá vinnu ættu pá ekki fleiri að fá vinnu ef fleiri ljúka námi? Í okkar heimshluta, norðvestanverðri Evrópu, virðist sambandið milli skólagöngu og atvinnupátttöku samt öfugt. Mynd 1 er byggð á gögnum sem eru í viðauka aftast í kaflanum. Hún sýnir samband milli atvinnuleysis á 20 ára tímabili og pess hve margir ljúka framhaldsskóla í tólf 
löndum. Löndin eru Belgía, Bretland, Danmörk, Finnland, Frakkland, Holland, Írland, Ísland, Lúxemborg, Noregur, Svípjóð og Pýskaland. Besta lína gegnum punktasafnið sýnir að menntunarstig eykst með auknu atvinnuleysi en ekki atvinnupátttöku. Dríhyrningurinn neðarlega til vinstri táknar Ísland.

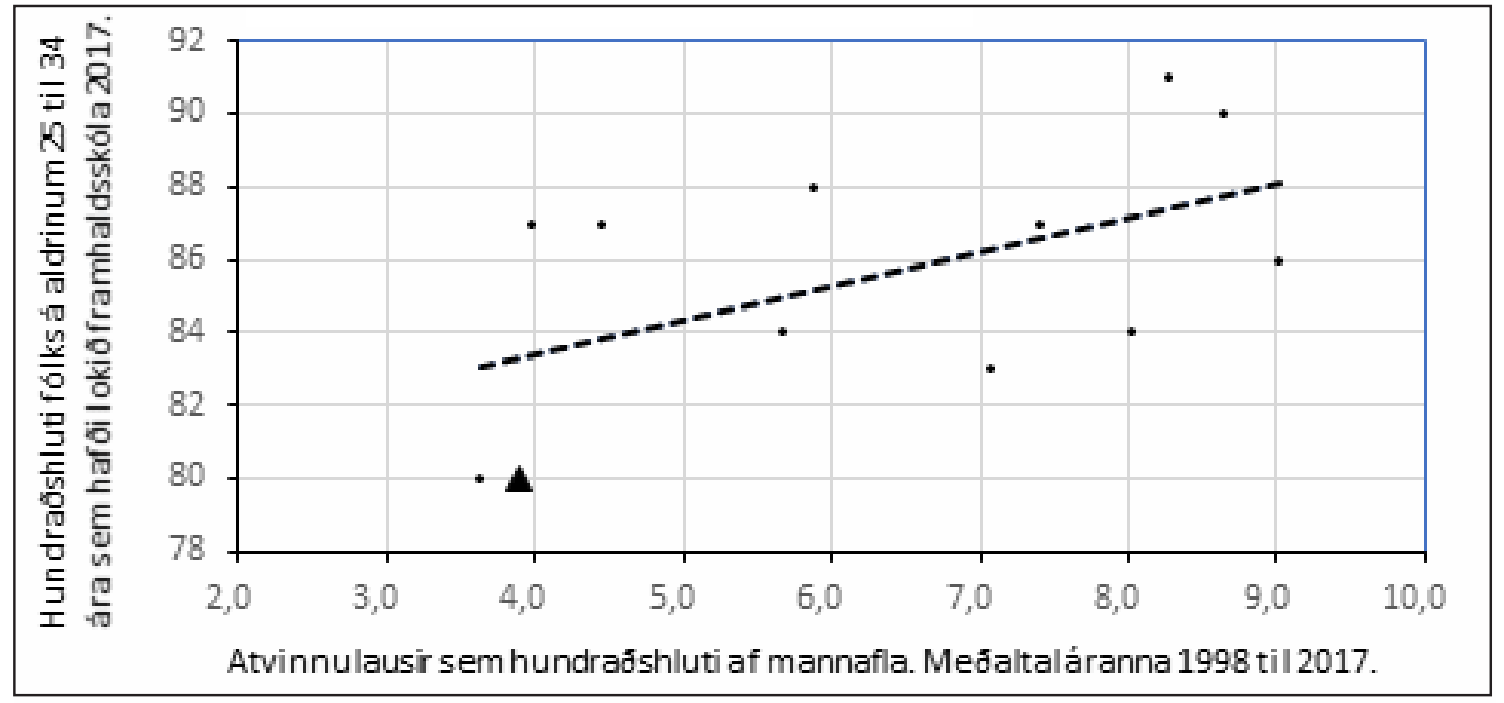

Mynd 4.1. Samband menntunarstigs við atvinnuleysi í norðvestanverðri Evrópu

Detta samband skólagöngu við atvinnuleysi ætti að vekja spurningar um gildi menntunar fyrir efnahagslífið. Раð ætti líka að kalla á umhugsun um hvaða vit sé í umræðu um að brottfall úr framhaldsskólum sé vandamál eins og yfirvöld menntamála hér á landi hafa, að minnsta kosti stundum, haldið fram (sjá t.d. Mennta- og menningarmálaráðuneytið, 2014). Má ekki alveg eins líta svo á að atvinnuleysi sé vandamálið og pað neyði fólk til að vera í skóla? Ef við horfum aðeins á Norðurlöndin pá kemur í ljós að hlutfall peirra sem ljúka framhaldsskóla hér á landi er á línunni eins og sést á mynd. ${ }^{4.2}$. Er petta hlutfall ef til vill einungis jafnhátt og búast má við í landi með svipaða samfélagsgerð og álíka lítið atvinnuleysi?4

Баð eitt að atvinnuleysi ýti undir skólasókn og unglingar hætti frekar í skóla ef auðvelt er að fá vinnu segir svo sem lítið um hagkvæmni menntunar. Vera má að sumir sem hætta í skóla vegna pess að peir fá vinnu fengju samt enn betri vinnu ef peir lærðu meira. Рað má líka vera að sumir sem halda áfram í skóla vegna pess að peir finna ekki vinnu sem peim líkar bæti möguleika sína á vinnumarkaði ekki neitt með meiri menntun. Рað parf að grafa dýpra til að komast að pví hversu góð eða slæm aukin skólaganga er fyrir efnalega afkomu fólks.

Ein af athyglisverðari tilraunum sem ég veit um frá síðustu árum til að skilja samband efnahags og skólagöngu var gerð af Bryan Caplan prófessor í hagfræði við George Mason-háskólann í Bandaríkjunum. Í bók sem kom út 2018 rökstyður hann að pótt flestir einstaklingar sem afla sér formlegrar menntunar umfram skyldunám bæti sinn eigin efnahag sé pað í meiri hluta tilvika á annarra kostnað og bæti ekki kjör heildarinnar.

\section{Getur gagnslaus skólaganga verið eftirsóknarverð?}

Caplan (2018) segir engan vafa leika á pví að í Bandaríkjunum njóti fólk sem hefur formlega menntun á háskólastigi að jafnaði betri kjara en aðrir. Hann segir að ríkjandi skýringar á pessu séu í anda mannauðsfræða og geri ráð fyrir að hærri laun langskólagenginna skýrist af pví að vinna peirra skapi meiri verðmæti. Dessar skýringar segir hann að séu ósennilegar. Fyrir pessu tiltekur hann meðal annars pau rök að stór hluti starfa sem háskólaborgarar vinna hafi engin tengsl við neitt sem peir lærðu í skóla. Önnur rök sem hann tiltekur eru að pegar meðalskólaganga heillar pjóðar lengist aukast tekjur hennar ekki að sama skapi eins og vænta mætti ef arður af vinnu ykist við lengri skólagöngu.

4.2. Vandađa umfjöllun um brottfall úr íslenskum framhaldsskólum bar sem međal annars er bent á mögulegt samband bess við hve auðvelt er að fá vinnu án pess að ljúka námi má t.d. finna í grein eftir Kristjönu Stellu Blöndal, Jón Torfa Jónasson og Anne-Christine Tannhäuser (2011). 


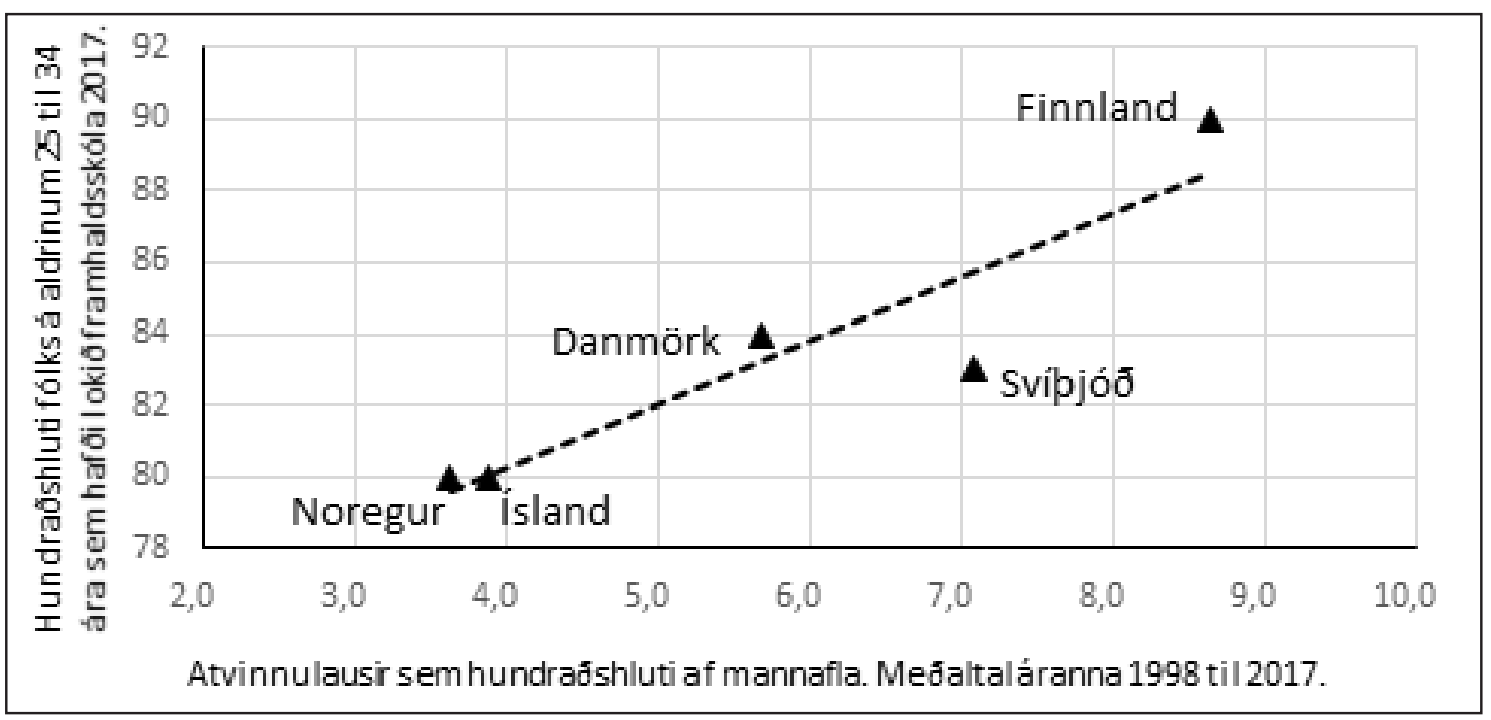

Mynd 4.2. Samband menntunarstigs við atvinnuleysi á Norðurlöndum

Hvers vegna skyldu langskólagengnir pá hafa hærri laun? Meginástæðan, segir Caplan, er sú að skólaganga eykur líkur á að fá vel launaða vinnu algerlega óháð pví hvort hún nýtist til að vinna betur en sami einstaklingur mundi gera án hennar. Að fólk með háskólagráðu komist fram fyrir aðra í röðinni pegar ráđið er í starf pýðir ekki endilega að nám pess gagnist til að vinna starfið. Í byrjun bókarinnar skýrir Caplan meginhugsun hennar með líkingu og segir að ef hann standi uppi á stólnum á tónleikum, í stað pess að sitja, pá sjái hann hljómsveitina betur par sem hnakkinn á manninum fyrir framan skyggi ekki á. Dað er pó ekki par með sagt við sjáum almennt betur ef allir standa uppi á stólnum sínum.

Hvers vegna skyldu menn með háskólagráđu eiga auðveldara með að fá vel launuð störf ef lærdómur peirra gagnast ekkert í vinnu? Til að skýra petta notar Caplan merkjakenningu (e. signaling theory) sem sækir innblástur í skrif pekktra hagfræðinga á borð við Michael Spence, Kenneth Arrow og Joseph Stiglitz. Merkjakenningar snúast um að skýra hegðun fólks á markaði pegar pað hefur takmarkaðar upplýsingar og læutur pví duga að nota vísbendingar um að petta eða hitt beri með sér pau gæði sem sóst er eftir.

Hugsum okkur fyrirtæki sem parf að ráða margt fólk í vinnu. Fyrirtækið vill helst starfsmenn sem geta lært til verka, eru iðjusamir og nógu pægir til láta vel að stjórn. Dað er of mikil fyrirhöfn að kynnast öllum umsækjendum og kanna kosti hvers og eins. Hvað gerir fyrirtækið? Dað á varla annars úrkosta en að kanna vísbendingar um að umsækjendur hafi pessa prjá kosti. Í nútímasamfélagi eru prófskírteini ríkjandi form merkja eða vísbendinga um pessa prenns konar kosti sem margir vinnuveitendur sækjast eftir. Fólk sem flaggar skírteinum er pví öðrum fremur tekið 1 atvinnuviðtöl pegar eftirsóknarverð störf eru auglýst. Eiginleikarnir sem skírteinin eru vísbendingar um eru oft eiginleikar sem menn afla sér ekki með löngu námi heldur purfa einfaldlega að hafa áđur en nám hefst til að geta lokið pví. Dess vegna fá peir sem hafa útskrifast úr skóla aðgang að vinnumarkaði. Eftir að starf er fengið, segir Caplan, veltur frami fólks svo meira á pví hvernig pað stendur sig en á pví hvaða prófgráđu pað hefur. Sitt er hvað, gráða og gjörvileiki. Prófgráðan er aðeins ótraust vísbending, en samt nógu góð til að pað borgi sig oftar en ekki fyrir fyrirtæki að nota hana.

Caplan byggir rök sín einkum á greiningu á tölfræðilegum gögnum um vinnumarkað og menntun í Bandaríkjunum. Pótt niðurstaða hans sé að stór hluti af formlegri menntun gagnist fólki á vinnumarkaði eingöngu vegna pess að skírteini eru aðgöngumiði að atvinnuviðtali neitar 
hann pví ekki að skólaganga auki stundum hæfni til starfa. Að hans mati eru sjónarmið peirra sem tala um mannauð ekki alröng. Hjúkrunarfræðingur sem vinnur við hjúkrun fær væntanlega hærri laun en ófaglært verkafólk vegna pess að bekkingin á faginu skiptir máli. Hjúkrunarfræðingur sem vinnur sem flugpjónn, lögfræðingur sem vinnur sem sölumaður og kennari sem afgreiðir í banka hafa pó að jafnaði hærri laun en flest ófaglært verkafólk án pess að menntun peirra nýtist beinlínis í starfinu.

Caplan reiknast til að aukin hæfni vegna menntunar skýri sennilega um fimmtung af launamun peirra Bandaríkjamanna sem hafa langa skólagöngu og peirra sem hafa stutta skólagöngu. Hann bendir á ástæður til að ætla að nám í rafvirkjun, pípulögnum og fleiri verkmenntagreinum á framhaldsskólastigi skili mönnum hærri ævitekjum einkum vegna pess að námið geri pá færari um að vinna verðmæet störf en sama gildi ekki um fjölmennustu háskólagreinarnar.

Caplan tekur skýrt fram að rök sín beinist alls ekki gegn almennri menntun fyrir börn og ekki heldur gegn peim sem telja að menntun sem fólk aflar sér í framhaldsskólum og háskólum sé verðmæe 1 sjálfri sér. Hann ræðir í pessu sambandi meðal annars um hve dýrmætt sé að læra að meta tónlist og bókmenntir. Rök hans beinast aðeins gegn peim sem halda að betri kjör langskólagenginna á vinnumarkaði skýrist einkum af pví að pað sem peir lærðu í skóla geri pá að betri starfsmönnum.

Hvort sem rannsóknir Caplans gilda um önnur lönd en Bandaríkin, og hvort sem pað er rétt mat að einungis minnihluti af formlegri menntun umfram skyldunám bæti tekjur nemenda beinlínis vegna pess að námið gagnist í starfi, er ljóst að skýringar hans sýna að pað er að minnsta kosti mögulegt að lengri skólaganga auki tekjumöguleika einstaklinga án pess að hún bæti efnahag heildarinnar.

\section{Á menntun að pjóna atvinnulífinu?}

Hugmyndin um að skólar pjóni atvinnulífinu vekur fleiri spurningar en pær sem Caplan ræðir enda er pað skrýtin hugmynd að jafn stórt svið mannlífsins og menntunin gegni aðeins pjónustuhlutverki. Hún er næstum jafn skrýtin eins og ef einhver héldi að heilbrigðiskerfið væri til pess eins að stuðla að árangri í ípróttum. Sennilega eru vensl menntunar og farsældar flóknari en svo að menntunin stuðli aðeins að efnalegri velmegun. Menntun er sjálf hluti af góðu lífi. Fólk sem á til hnífs og skeiðar bætir líf sitt til dæmis með pví að læra að meta tónlist og bókmenntir ekkert síður en með pví að eignast meiri peninga.

Atvinnurekendur nítjándu aldar vildu sjálfsagt flestir að piltar lærðu að slá með orfi og ljá og róa til fiskjar á opnum bátum og að stúlkur kynnu að sitja lömb og spinna ull. Detta var vissulega parft og nauðsynlegt. Atvinnuhættir tuttugustu aldar spruttu pó ekki af pessari kunnáttu heldur miklu fremur af pví bókviti sem sagt var að yrði ekki í askana látið. Framfarir síðustu aldar voru ekki síst afsprengi frjálsra lista: Vísindalegrar hugsunar, rökvísi og tungumálakunnáttu. Dótt flest störf krefðust ef til vill lítillar pekkingar á vísindum og fræðum var samt væntanlega samband milli pess háttar menntunar annars vegar og hæfni til nýsköpunar, uppfinninga og ýmissa framfara hins vegar.

Við getum horft á atvinnulíf nítjándu aldar úr fjarlægð og pakkað fyrir að skólar pess tíma kenndu fleira en pá purfti að nota í vinnu. Er ekki sennilegt að á næstu öld og parnæstu segi menn pað sama um okkar tíma og verði ánægðir með að margir lærðu annað en nú parf til að vinna fyrir sér?

Atvinnulíf framtíðarinnar verður væntanlega öđru vísi en atvinnulíf dagsins í dag og hvað úr bví verður veltur meðal annars á pví hvaða pekkingar menn afla sér nú umfram pá sem parf að nota á vinnustöðum samtímans. Detta ætti raunar að vera augljóst. Ef margir læra tónlist, leiklist og kvikmyndagerð pá verða nokkru seinna til fyrirtæki sem selja eitthvað á borð við sjónvarpspætti og ef margir læra líffræði og efnafræði verða kannski til fyrirtæki sem framleiða snyrtivörur. 
Ef hópur fólks lærir eitthvað sem fólk á mínum aldri botnar ekkert í og veit varla hvað heitir pá verður mögulega til eitthvað sem ég á engin orð yfir. Af pessum sökum er sú hugmynd að skólakerfi skuli lagað að pörfum atvinnulífs nútímans ekki einungis óraunsæ. Hún er trúlega einnig óheppileg fyrir atvinnulíf framtíðarinnar.

\section{Til umhugsunar}

Hugsum okkur að pað sem Caplan segir sé að mestu leyti rétt og par með að pegar eftirsóknarverð störf af einhverju tagi eru auglýst purfi til dæmis meistaragráðu úr háskóla til að komast í atvinnuviðtal pótt raunin sé að nýliði læri starfið að mestu á vinnustað eftir að hann hefur verið ráđinn. Hugsum okkur líka að petta valdi pví að fólki með meistaragráđu fjölgi smám saman pví menn leggi á sig skólagöngu til að eiga kost á góðri vinnu. Ef petta gerist hlýtur að koma að pví að flestir umsækjendur verði með meistaragráðu og fyrirtækin og stofnanirnar sem ráða fólk verði að sigta úr umsóknum með pví að líta á eitthvað annað en prófgráður.

a) Hvað ætli verði um aðsókn að háskólum ef vísbendingarnar sem vinnuveitendur nota verða ótengdar háskólanámi, skírteinum og einkunnum? Hvað ef fyrirtæki sem ráđa marga taka til dæmis upp á að nota einhvers konar inntökupróf eða upplýsingar af pví tagi sem Google og samskiptamiðlar safna nú um flest fólk?

b) Hvort er betra að læra að skapa meiri auð eða að læra að njóta gæða sem hægt er að fá fyrir litla eða enga peninga?

c) Hefur nokkurn tíma verið auðveldara að komast af með litla pekkingu?

d) Skapa peir sem hafa langa skólagöngu að jafnaði meiri efnahagsleg verðmæti en peir sem hafa stutta skólagöngu?

e) Getum við vitað núna hvaða kunnátta verður verðmæt fyrir atvinnulífið eftir tuttugu ár?

\section{Viðauki}

Tafla. 4.1. Gögn um atvinnuleysi og hlutfall framhaldsskólamenntaðra í norðvestanverðri Evrópu.

\begin{tabular}{|c|c|c|}
\hline Land & $\begin{array}{l}\text { Meðalatvinnuleysi 1998-2017 } \\
\text { sem hlutfall af heildarmannafla. }^{a}\end{array}$ & $\begin{array}{l}\text { Hve stór hluti fólks á aldrinum } 25 \text { til } 34 \text { ára } \\
\text { hafði lokið framhaldsskóla í árslok 2017.b }\end{array}$ \\
\hline Belgía & $8 \%$ & $84 \%$ \\
\hline Bretland & $6 \%$ & $88 \%$ \\
\hline Danmörk & $6 \%$ & $84 \%$ \\
\hline Finnland & $9 \%$ & $90 \%$ \\
\hline Frakkland & $9 \%$ & $86 \%$ \\
\hline Holland & $4 \%$ & $87 \%$ \\
\hline Írland & $8 \%$ & $91 \%$ \\
\hline Ísland & $4 \%$ & $80 \%$ \\
\hline Lúxemborg & $4 \%$ & $87 \%$ \\
\hline Noregur & $4 \%$ & $80 \%$ \\
\hline Svípjód & $7 \%$ & $83 \%$ \\
\hline Pýskaland & $7 \%$ & $87 \%$ \\
\hline \multicolumn{3}{|c|}{$\begin{array}{l}\text { a Gögn um atvinnuleysi sem hlutfall af heildarmannafla árin } 1998 \text { til } 2007 \text { eru fengin úr OECD } \\
\text { (2011, bls. 57). Gögn um atvinnuleysi sem hlutfall af heildarmannafla árin } 2008 \text { til } 2017 \text { eru } \\
\text { fengin úr OECD (2018a, bls. 37). }\end{array}$} \\
\hline \multicolumn{3}{|c|}{$\begin{array}{l}\text { b Gögn um menntunarstig } 25 \text { til } 34 \text { ára árið } 2017 \text { eru fengin úr OECD (2018b, bls. 56). Ensku } \\
\text { orðin „upper secondary education“ eru býdd með orðinu „framhaldsskóli“. }\end{array}$} \\
\hline
\end{tabular}




\section{Skólaganga, menntun og siðferði}

Í Heilræðavísum Hallgríms Péturssonar (1931, bls. 199) sem ortar voru á sautjándu öld segir:

Lærður er í lyndi glaður, lof ber hann hjá pjóðum, hinn er ei nema hálfur maður, sem hafnar siðum góðum.

Oft er sá í orðum nýtur, sem iðkar menntun kæra; en pussinn heimskur pegja hlýtur, sem prjózkast við að læra.

Af fyrri vísunni má ráđa að Hallgrímur hafi talið lærdóm gera fólk glaðara og bæta siðferði pess. Af peirri seinni má æetla að hann hafi álitið lærdómsmenn hafa meira til málanna að leggja heldur en annað fólk.

Viðhorfin sem birtast í pessum tveimur vísum eru raunar fremur dæmigerð fyrir bað sem talsmenn frjálsra lista hafa sagt um gildi menntunar í tvö púsund ár. Deir gerðu yfirleitt ráð fyrir að lærdómur væri mannbætandi og hefðu líklega flestir tekið undir bað sem Sveinbjörn Egilsson (1968, bls. 21) sagði í ræðu við skólasetningu í Bessastaðaskóla árið 1819: „Vér lærum ekki til að verða lærðir, heldur til að verða góðir." Sambærilega áherslu á mannbætandi nám má víða finna í umfjöllun um skólastarf frá nítjándu öld. Í reglugerð fyrir Lærða skólann frá árinu 1850 segir til dæmis að skólinn eigi ,að sjá um að piltar verði guðræknir og siðprúðir“ (Kristinn Ármannsson o.fl., 1975, bls. 19).

Dessar tilvitnanir í íslensk skrif frá sautjándu og nítjándu öld eru ekki aðeins minjar um hugsun liðinna alda heldur vitnisburður um trú á gildi menntunar sem gengur sífellt í endurnýjun lífdaga. Hennar sér til dæmis stað í skrifum Páls Skúlasonar (2014, bls. 14) heimspekings og fyrrum háskólarektors frá pessari öld par sem hann ræðir um að menntunin efli mennsku okkar.

Ef hugtakið menntun er skilið svo að pað nái yfir alla góða eiginleika sem fólk öðlast með lærdómi, pjálfun, tilsögn, umhugsun og reynslu pá verður tæpast um pað deilt að menntun bæti fólk. Við getum skilgreint menntun sem proska „eftirsóknarverðra hæfileika“ svo notað sé orðalag úr pýðingu Gunnars Ragnarssonar á grein eftir Dewey (2010, bls. 197) og pá segir sig sjálft að menntun er eftirsóknarverð. Að halda pví fram að pað sé til bóta að hafa góða eiginleika er álíka upplýsandi og að segja að gift fólk sé í hjónabandi. Sé hugtakið menntun skilið svona pá blasir við að menn geta lært án pess að menntast. Dað er til dæmis hægt að læra ósiði, klæki, fantabrögð og margt fleira sem gerir fólk verra en ekki betra. Af pví að menntun sé alltaf til bóta leiðir pví alls ekki að allur lærdómur sé pað. 
Vissulega er hægt að færa ýmisleg rök fyrir pví að margvíslegur lærdómur hafi að jafnaði góð áhrif á fólk. Enginn hefur pó, mér vitanlega, sett fram sannfærandi rök fyrir að petta gildi um hvaðeina sem menn læra í skóla. Рað hlýtur líka að teljast afar ósennilegt að skólar veiti ævinlega betri menntun - gefi fólki fleiri góða eiginleika og færri slæma - en önnur reynsla sem hægt er að afla sér, til dæmis með vinnu, pátttöku í félagslífi og stjórnmálum, listrænni sköpun eða lestri og pælingum utan skóla. Рað er pví varhugavert að leggja að jöfnu gildi menntunar og gildi skólagöngu.

Í síðasta kafla var sagt stuttlega frá efasemdum um að löng skólaganga porra fólks sé gagnleg fyrir atvinnulífið. Dessar efasemdir eru hluti af andófi gegn skólum og skólagöngu og slíkt andóf hefur, rétt eins og áherslan á lærdóm sem eflir siðferði og sanna mennsku, verið hluti af samræðu lærðra manna um menntamál í margar aldir. Í pví sem hér fer á eftir verður fjallað nokkuð vítt og breitt um andóf gegn skólum og skólagöngu, flakkað fram og aftur um síðustu fimm aldir og endað á áhrifamesta andófsmanninum sem var Jean-Jacques Rousseau.

Eina gerð efasemda um gagnsemi skóla má finna í skrifum Wolfgangs Edelstein sem höfðu veruleg áhrif á skólamálaumræðu hér á landi undir lok síðustu aldar. Í greinasafni sem kom út árið 1988 segir hann frá skoðunum svissneska barnasálfræðingsins Jean Piaget og gerir pær um leið að sínum eigin:

Vitund barns bregst við reynslu með námi. Dekkingaröflun er hluti af líffræðilegu eðli og arfleifð mannsins. Рað parf pví meira en smátilfæringar til að hamla forvitni barns og kæfa pekkingarlyst pess. Loks sér Piaget - líkt og aðrir gagnrýnendur skólans - að nokkur ár í skóla virðast nægja til að láta saltið dofna, skerða námsviljann og slökkva námsfjör fjölda barna. (Wolfgang Edelstein, 1988, bls. 165-166).

Parna er nánast látið að pví liggja að skólar komi í veg fyrir að börn læri. Wolfgang Edelstein telur petta pó ekki óhjákvæmilegt heldur aðeins einkenni á skólum sem enn eru frumstæðir. Hann segir svo í framhaldinu að með framförum í menntavísindum standi petta til bóta.

Eins og nefnt var í öðrum kafla andmælti John Locke skólahaldi eins og hann sjálfur kynntist af eigin raun og sagði að pað gerði börn pýlynd fremur en stolt og frjálsmannleg. Hann taldi raunar betra að foreldrar kenndu börnum sínum heima en að pau væru send í slíka skóla. Andmæli hans byggðust að nokkru á eldri skrifum, einkum pví sem Frakkinn Michel de Montaigne ritaði á sextándu öld. Montaigne skóf ekkert utan af pví pegar hann sagði að ekki væri sjón að sjá nemanda eftir fimmtán til sextán ára skólagöngu. Ekki yrði merkt að honum hefði farið fram á annan hátt en pann að latínan og grískan hefðu gert hann montnari og hrokafyllri en hann var áður en hann fór að heiman - tímanum væri betur varið við að leika tennis heldur en við nám sem hvorki bætti hræringar sálarinnar né stuðlaði að heilbrigðari dómgreind: Tennis liðkaði að minnsta kosti líkamann (Montaigne, 1991, bls. 156).

Ef ég skil Montaigne og Locke rétt hugðu peir báđir, líkt og Wolfgang Edelstein, að pótt skólar sem peir bekktu gerðu nemendum skaða fremur en gagn væri að minnsta kosti mögulegt að til yrðu öðru vísi og betri skólar. Aðrir hafa gengið lengra og talið best að leggja allt skólahald af fremur en að reyna að betrumbæta pað.

Einn af frægustu andstæðingum skólahalds á síðustu öld var Austurríkismaðurinn Ivan Illich sem var í senn kapólskur prestur og heimspekingur. Bók hans Afskólun samfélagsins kom upphaflega út árið 1971. Dar mælir Illich með að bakkað verði út úr skólavæðingu samfélagsins og að mismunun á grundvelli skólagöngu verði bönnuð, sem pýðir að hætt verði með öllu að láta skólagöngu veita forgang á vinnumarkaði. Hann lýsir skólavist ungmenna sem langdregnustu og leiðinlegustu manndómsvígslu í gervallri veraldarsögunni og skelfilegri sóun á tíma og tækifærum. Hann segir líka að pað sé að jafnaði betra fyrir stálpuð börn og unglinga að vinna með fullorðnu fólki að en sitja á skólabekk og skattalög ættu að hvetja vinnuveitendur til að ráða fólk milli 8 og 14 ára til að vinna hluta af degi. 
Dví fór pó fjarri að Illich væri andvígur lærdómi og menntun. Hann taldi einfaldlega betra að petta færi fram með óformlegum hætti par sem allir væru í senn kennarar og nemendur og fólk kenndi hvert öðru ævilangt. Í sjötta kafla bókarinnar lýsir hann draumi sínum um betra menntakerfi og segir að pað ætti að hafa prenns konar markmið: Að veita öllum sem vilja læra tækifæri og aðstöðu til pess; gefa öllum sem vilja deila pekkingu sinni möguleika á að komast í samband við fólk sem vill læra af peim; veita öllum tækifæri til að koma pví sem peir hafa að segja á framfæri við almenning (Illich, 1995). Í pessum sama kafla segir hann að rétturinn til að deila pekkingu sinni eigi að teljast til almennra borgararéttinda en ekki sérréttinda fólks með tiltekin prófskírteini. Pessi vegna eigi ekki að lögvernda starfsréttindi kennarastéttarinnar.

Andmæli Illich gegn skólagöngu sverja sig að pví leyti í ætt við kenningar Lockes að Illich taldi líka að skólar hefðu slæm áhrif á siðferði fólks. Helst er að skilja að hann hafi talið að skólar gerðu fólk ábyrgðarlaust og hvettu til pess að meira væri sóst eftir prófgráðum og sérréttindum en pekkingu og proska.

Illich tók harða afstöðu gegn skólagöngu og sama má segja um ýmsa andófsmenn gegn skólum sem vekja athygli nú á okkar tímum eins og til dæmis bandaríska kennarann John Taylor Gatto (1992/2017) sem heldur pví fram að skólinn sé fangelsi og eina námsefnið sem börn læri par í raun og veru sé slæmar venjur. Hjá sumum efasemdamönnum um skólahald er tónninn heldur mildari. Hér má til dæmis nefna rússneska nítjándu aldar skáldið Leo Tolstoj sem aðeins var sagt frá í priðja kafla. Hann var ekki beinlínis mótfallinn skólum enda starfrækti hann sjálfur barnaskóla um árabil. Hann var pó á móti skólaskyldu og nemendur hans höfðu um pað fullt frelsi hvort peir mættu í tíma. Starfið var fremur óformlegt og frjálslegt. Bó hékk uppi tímatafla í kennslustofunni og par var skólabjalla.

Tolstoj lagði áherslu á að kennarar hefðu frelsi til að vinna samkvæmt eigin hugsjónum og var mótfallinn hugmyndum sem uppi voru um miðstýrt kerfi ríkisskóla. Einkum var honum í nöp við miðstýrt mat á námi og kennslu sem hann áleit að leiða mundi til mannskemmandi metings og keppni og pess að kennarar sem hirtu lítt um heill nemenda byggju pá einkum undir próf og kæmu pví betur út en bestu kennararnir sem létu sér annt um nemendur sína (Moulin, 2014).

Deir efasemdamenn um gildi skólagöngu sem hér hafa verið nefndir vefengja ekki gildi lærdóms og pekkingar á vísindum og fræðum, listum og tækni. Hér er Tolstoj pó ef til vill undantekning pví í skáldsögum hans, sem pykja með dýrustu perlum bókmenntasögunnar, birtast djúpar efasemdir um að lærdómur geri fólk að betri manneskjum. Annað af tveimur pekktustu verkum hans er skáldsagan Stríð og friður sem út kom 1869. Par kynnast lesendur auðugum aðalsmanni sem hét Pétur Besúkof. Í fyrstu köflum sögunnar er hann hrifinn af hugsjónum frönsku byltingarinnar og reynir að lifa eftir peim með pví að bæta kjör ánauðugra bænda. Að lögum pess tíma taldist hann eiga kotungana eins og hvern annan búpening en sagan gerðist milli 1805 og 1820, um hálfri öld áđur en bændaánauð var aflétt í Rússlandi. Pétur gaf verkstjórum sínum fyrirmæli um ýmsar umbætur. Degar hann svo heimsótti landareignir sínar ,leit hann yfir reikninga verkstjóranna; samkvæmt peim hafði verið dregið úr prældómi bændanna, og hann hlýddi á hjartnæm pakkarorð bændanefndar, sem kom á fund hans“" (Tolstoj, 1986, 3. bindi, bls. 170-171). Hann vissi samt ekki að pað voru hinir best settu meðal bændanna sem nýttu sér ,umbæturnar“ meðan meiri hlutinn lifði við sömu örbirgð. Hann taldi sig hafa komið á skólum fyrir börn bændanna en ,vissi ekki, að presturinn, sem kom á móti honum með krossinn á lofti, kúgaði fórnir af kotungunum, né heldur, að peim sveið sárt að sjá af börnunum í skólann frá störfum heima, en prestur seldi foreldrum barnanna lausn peirra frá skólasókn dýru verði“ (Tolstoj, 1986, 3. bindi, bls. 171).

Stríð og friður er að nokkru leyti proskasaga Péturs og hann lét af peim barnaskap að rétta kjör fátæklinga með skipunum ofan frá sem, eftir pví sem sagan segir, gögnuðust peim einum sem voru á næstu tröppu fyrir neðan húsbóndann en alls ekki peim sem báru minnst úr býtum og minnst 
frelsi höfðu. Í sögulok er hann orðinn góður maður og vitur, ,samúð með öðrum mönnum skein úr augnaráđinu, og öllum leið vel í návist hans“ (Tolstoj, 1986, 4. bindi, bls. 173).

Mikilvægustu skrefin á proskabrautinni steig Pétur með miklum kvölum pegar hann var stríðsfangi og kynntist fátækum bónda sem hér Karatajef. Рað var pessi albýðumaður sem gaf honum tilfinningu fyrir pví að guð væri alls staðar nálægur og opnaði augu hans fyrir pví „mikla, eilífa og óendanlega í öllum hlutum“ (Tolstoj, 1986, 4. bindi, bls. 173). Karatajef var einföld sál og alger andstæða skólagenginna yfirstéttarmanna.

Annað af helstu stórvirkjum Tolstojs er skáldsagan Anna Karenína sem út kom átta árum seinna en Stríð og friður eða 1877. Ein af aðalpersónum peirrar sögu er Konstantin Dimitritsj Ljovin og saga hans er proskasaga eins og saga Péturs Besúkof. Ljovin er eins og álfur út úr hól í samfélagi heldra fólks og fákunnandi um valdsorðaskak og klæki rússneska aðalsins. Hann er einlægur og heiðarlegur og leitar sannleikans en er vantrúaður á frjálslynd viðhorf sem voru í tísku hjá menntuðu fólki. Í sögulok er hann samt maðurinn sem fólk treystir og bæði aðalsmenn úr hans eigin fjölskyldu og kotungar úr sveitinni koma til hans með áhyggjur sínar. Líkt og Pétur lærir Ljovin pá lífsleikni sem dugar af albýðumanni, bónda sem heitir Fjodor. Undir sögulok ræða peir um innheimtu landskulda afjörð sem Ljovin átti allfjarri heimili sínu. Ljovin spurði hvort Tokanytsj, bóndi úr sama porpi, ríkur og pekktur að góðvild, mundi ekki vilja taka pessa jörð á leigu. Fjodor svarar og segir að pað gangi ekki, leigan sé of há og pó peir sem engum hlífa geti innheimt af kotungum til að borga landskuldina, geti Tokanytsj pað ekki pví hann sé maður með hjartaðá réttum stað: „Hann lifir fyrir sál sína. Hann hugsar um guð“ (Tolstoj, 1941-1944, 4. bindi, bls. 123). Við pessi orð alpýðumannsins opnuðust augu Ljovins og hann sá að hugmyndir menntaðra manna um arðbæran rekstur voru of ömurlegar til að fara eftir peim.

Degar Ljovin hefur numið pað af ómenntuðum albýðumanni að best sé að hugsa um sál sína og lifa í guði barnar Tolstoj söguna með pví að benda á að pessi lærdómur sé víðs fjarri allri vísindalegri skynsemi sem kennir mönnum að lögmál náttúrunnar sé að hver og einn reyni að uppfylla sínar eigin óskir og brjóta aðra á bak aftur. Niðurstaða Ljovins er að á mælikvarða lærdóms og vísinda sé ekkert vit í pví að elska náunga sinn.

Detta sama stef, að menntuð yfirstétt purfi að læra lífsleikni af einföldum og trúuðum alpýðumönnum, kemur víðar fyrir í ritum Tolstojs. Ein af seinni sögum hans heitir Dauði Ivans Ilych. Hún er heldur nöturleg frásögn af lögfræðingi og dómara sem fær banvænan sjúkdóm og deyr. Hann hafði alla sína tíð verið upptekinn af lífsgæðakapphlaupi og samanburði við aðra vel stæða borgara en andspænis dauðanum sá hann hvað petta var allt tilgangslaust. Eini maðurinn sem gat hjálpað honum var pjónn af lágum stigum, bóndasonur sem hét Gerasim. Hann var jafnan glaður prátt fyrir lága stöðu í samfélaginu, pjónaði af góðmennsku og lét pað ekki fipa sig pótt húsbóndinn væri við dauðans dyr. Allir aðrir forðuðust að tala um dauðann og gengu inn í leik lyga og blekkinga par sem var látið eins og sjúklingnum mundi batna. „Gerasim var sá eini sem ekki laug. Рað var ljóst af öllu sem gerðist að hann einn gerði sér grein fyrir staðreyndum málsins, fannst ónauðsynlegt að breiða yfir pær en kenndi einfaldlega í brjósti um lasburða og máttfarinn húsbónda sinn“" (Tolstoy, 2010, bls. 83).

Gerasim var sem sagt nógu heilsteyptur til að geta tekið pví hlutskipti manna að deyja án pess að fara undan í flæmingi, en Ivan kynntist Gerasim of seint til að læra af honum. Hann komst ekki lengra en að skynja rétt svo að pað væri meira vit í trú pessa ómenntaða manns en allri hámenningu og lærdómi yfirstéttarinnar. Degar hann undir sögulok horfir á andlit Gerasims nær hann að spyrja sjálfan sig: „Hvað ef ég hef lifað öllu lífinu rangt?“ (Tolstoy, 2010, bls. 83). Lengra kemst hann ekki, við tekur kvalafullt dauðastríð, og pess vegna er sagan um Ivan Ilych miklu nöturlegri en sögur Péturs Besúkof og Ljovins.

Svipaðar efasemdir um gildi lærdóms má finna hjá öđru stórskáldi nítjándu aldar, Bandaríkjamanninum Herman Melville, sem pekktastur er fyrir bókina um hvíta hvalinn Moby Dick. Síðasta sagan sem hann sendi frá sér fjallar um Billy Budd sjómann. Dar segir Melville (2014) 
frá einföldum manni og hjartahreinum sem laðaði ætíð fram pað besta hjá skipsfélögum sínum. Hann var ólæs en hann gat sungið. Líkt og næturgalinn sem líka er ólæs samdi hann stundum sína eigin söngva.

Í upphafi sögunnar er Billy Budd sjómaður á kaupskipi undir lok átjándu aldar. Á pessum tíma stóðu Bretar í sjóhernaði, flotinn sótti sér sjómenn eins og hentaði og menn voru ekki spurðir hvort peir vildu ganga í herinn. Billy var valinn úr áhöfn kaupskipsins. Hann tók pví með jafnaðargeði og varð fljótt hvers manns hugljúfi á herskipinu. Dó var par einn maður sem lagði fæð á hann. Sá hét John Claggart. Hann var slóttugur maður og undirförull og poldi illa hvað Billy var vinsæll svo hann laug upp sökum og sagði skipstjóra að Billy ráđgerði uppreisn um borð. Umliðin misseri höfðu verið róstur í sjóhernum svo yfirmenn lögðu mikið upp úr ströngum aga.

Skipstjórinn trúði ekki pví sem Claggart sagði. Ekki var pó um annað að ræða en kalla Billy til yfirheyrslu. Pegar sakirnar voru bornar á hann varð hann algerlega orðlaus og gat ekki stamað upp neinu svari, enda átti hann stundum erfitt um mál. Í fátinu sem á hann kom slæmdi hann hendi til Claggarts sem féll, sló hausnum við og dó. Dessu lyktaði svo að Billy var hengdur fyrir að drepa yfirmann sinn. Sögupráðurinn segir minnst um petta meistaraverk Melvilles. Pað er fyrst og fremst lýsing á góðmennsku og illmennsku og sú lýsing er ansi mögnuð.

Claggart var menntaður maður sem kunni fína siði en enginn kunni vel við hann. Pótt hann gæti að nokkru marki falið eigið innræti átti hann pess engan kost að vera góður í gegn eins og Billy. Um menn eins og hann segir Melville að peir sem eru nógu rækilega siðspilltir séu gjarna hagsýnir og útsmognir í meira lagi pví peir sem hafa allt að fela pjálfist í klækjum. Billy var líka takmarkaður á sinn hátt pví hann gat engan veginn séð við klókindum og slægð. Hann átti sér pví einskis ills von pegar bornar voru á hann lognar sakir. Hann hafði, segir sögumaður, ekki pá innsýn í illskuna sem verri menn öðlast af sjálfum sér.

Hvað eigum við að halda um pessar sögur? Sýna pær að sönn góðmennska finnist ekki síður hjá ólæsu fólki og fákunnandi en peim lærðu og skólagengnu?

Flestar kenningar um siðferðilegt uppeldi gera ráð fyrir að bókleg fræði og skilningur á hugtökum og orðaforða um rétt og rangt, dygðir og lesti, gegni að minnsta kosti einhverju hlutverki í siðferðisproska. Detta á bæði við um kenningar Lawrence Kohlberg, sem mótuðu hugmyndir marga menntunarfræðinga um siðferðisproska á lokaáratugum síðustu aldar og kenningar um skapgerðarmenntun í anda Aristótelesar sem hafa notið hylli á pessari öld og margir pekkja af skrifum Kristjáns Kristjánssonar (Atli Harðarson, Ólafur Páll Jónsson, Róbert Jack, Sigrún Sif Jóelsdóttir og Póra Björg Sigurðardóttir, 2018; Power, Higgins og Kohlberg, 1989; Kristján Kristjánsson, 2015, 2018). Pó finnast virtir fræðimenn á sviði siðfræði sem hafa bent á að lærdómur kunni stundum að vera tvíeggjað sverð. Einn peirra er Englendingurinn Bernard Williams en skrif hans um siðfræðileg efni skipa honum á bekk með helstu heimspekingum síðustu aldar.

Williams gerði greinarmun á pví að vilja gera öðrum gott og að vilja sýnast góður í eigin augum eða annarra. Раð síðarnefnda kallar hann siðferðilegt sjálfsdekur. Hann segir líka að pótt dygð á borð við örlæti krefjist pess að menn stjórnist af hugsun um að gefa sé ekki par með sagt að örlátur maður hugsi um örlæti sitt. Manneskjur sem eru að sönnu örlátar hugsa fremur um parfir og líðan annarra en um sínar eigin dygðir. Рað sama á við um fleiri siðferðilega mannkosti. Рað er munur á pví að láta sér annt um annað fólk og pví að vera umhugað um að fá sjálfur góða einkunn fyrir hegðun og innræti. Menn geta, segir Williams (1981, 3. kafli), látið sér annt um aðra og verið drifnir af siðferðilega lofsverðum hvötum án pess að hafa flókin hugtök á valdi sínu. Sjálfsdekrið krefst hins vegar meiri meðvitaðrar hugsunar. Ef petta er rétt er lærdómur ef til vill beggja handa járn sem getur spillt mönnum á vissan hátt pótt hann geti líka bætt pá.

Sögur eins og pær sem Tolstoj og Melville sömdu vekja spurningar af svipuðu tagi og Bernard Williams glímdi við. Lesandi fær að minnsta kosti ástæður til að staldra við og spyrja sig hvort formleg menntun og skólaganga geri fólk ævinlega að betri manneskjum og hvort óskólagengnir 
menn eins Karatajef, Fjodor, Gerasim og Billy Budd geti staðið lærdómsmönnum framar í lífsleikni og siðferði.

\section{Rousseau}

Af heimspekingum seinni alda er Rousseau sá sem setti fram áhrifamestu efasemdirnar um menntagildi lærdóms og höfðu kenningar hans áhrifá pá báđa, Tolstoj og Melville (Berlin, 2011; Moulin, 2014; Rollyson, Paddock og Gentry, 2007). Rousseau, sem var frá Genf í Sviss, skrifaði á frönsku og voru mörg rita hans andóf gegn upplýsingarstefnunni og áhrifum frá Locke sem mótuðu pankagang franskra menntamanna í vaxandi mæli á átjándu öld.

Rousseau kvaddi sér hljóðs árið 1750 með Ritgerð um vísindi og listir (Discours sur les Sciences et les Arts). Dar ræðir hann spurninguna hvort endurreisn vísinda og lista hafi bætt siðferði fólks og svarar henni neitandi. Um pessi skrif Rousseaus sagði Jón Espólín, einn helsti boðberi upplýsingarstefnunnar á Íslandi í byrjun nítjándu aldar:

Hefir hann sett saman bók um pað, að vísindi og lærdómur og öll kunnusta hafði gjört mannkyninu eina saman ólukku, og vildi láta náttúrustand, pvílíkt sem pað enn er, og án skynsemdarbrúkunar, vera sælast. (Jón Espólín, 1982, bls. 169)

Rousseau (1964) endar ritgerðina á að gefa í skyn að sönn dygð búi í sálum einfaldra manna og ómenntaðra. Dessi kenning hans var mjög andstæð hugmyndum flestra upplýsingarmanna um mannbætandi áhrif lærdóms og vísindalegrar hugsunar, enda var hann, eins og Jón Espólín segir, „aldrei [...] á einu máli með Voltaire“ (Jón Espólín, 1982, bls. 169).

Rousseau hélt áfram að andmæla menntastefnu upplýsingarmanna í bókinni Émile sem út kom árið 1762. Sú bók er að nokkru leyti svar við Hugleiðingum um menntamál eftir Locke sem sagt var frá í öðrum kafla. Um pá stefnu Lockes að rökræða við börn sagði Rousseau að byrjað væri „,́ öfugum enda, að ætla að nota afurðina sem tæki. Ef börn skildu skynsamleg rök pá byrfti ekki að ala pau upp“ (Rousseau, 1991, bls. 89).

Skólar í anda upplýsingarinnar miðluðu börnum pekkingu og gerðu ráð fyrir að peim væri gott аð læra alls konar fræði sem hinir fullorðnu kynnu. Rousseau vildi hins vegar að menning fullorðna fólksins hefði sem minnst áhrif á börnin. Hlutverk uppalandans, sem frá segir í Émile, var fyrst og fremst að skapa aðstæður par sem barnið lærði af náttúrunni. Hann hafði litla trú á gildi bóklegra fræða. „Barn sem les hugsar ekki“ sagði hann (Rousseau, 1991, bls. 168).

Hvernig átti barn pá að læra samkvæmt Rousseau ef ekki átti að nota kennslubækur eða miðla pekkingu? Meginaðferðir uppalandans í Émile voru að setja upp aðstæður par sem barnið lærði af eigin reynslu og náttúran og hlutirnir kenndu pví pað sem purfti að vita. Saman við petta blönduðust hugmyndir um að einfalt lífí skauti náttúrunnar, líkt og Rousseau hugði að lifað væri meðal bjóða sem Evrópumenn töldu frumstæðar, væri betra en menning Frakka og annarra bjóða sem töldu sig upplýstar og menntaðar. Rousseau áleit samfélagið og menninguna í Frakklandi, með allri sinni stéttaskiptingu og kúgun, ala á metingi og hégóma, pýlyndi og hroka ásamt fleiri löstum. Lærdómur í skóla var að hans mati ekki leið út úr peim ógöngum heldur pvert á móti til pess að festa í sessi samfélagshætti sem spilltu fólki.

Að baki menntaheimspeki Rousseaus býr sú trú hans að náttúran ali af sér óspillt fólk og börn fæðist með möguleika á að verða góðar manneskjur en samfélagið spilli peim. Hann taldi að börn pyrftu ekki að læra siðferði af fullorðnum pví guð hefði gefið peim samvisku og skráð í hjörtu peirra hvað væri rétt og hvað rangt. Pessi hugmynd um að gott siðferði væri innbyggt i fólk fremur en lært var ekki ný hjá Rousseau. Locke (1993a, bls. 52) hélt raunar svipuðum hugmyndum fram og margir aðrir kristnir hugsuðir en Rousseau gerði hana að kjarna menntaheimspeki sinnar og bjó um leið til draumsýn um óspillt náttúrubörn. Dessi draumsýn heillar enn í dag marga sem 
hugsa um uppeldi og menntun. Hún var kannski ein af forsendum pess að bókmenntir næstu aldar kynntu persónur eins og Billy Budd sjómann og vitru albýðumennina í sögum Tolstojs.

Dewey, sem annars vefengdi margt í menntastefnu Rousseaus, taldi að áhersla hans á að hvert barn fæddist óspillt hefði verið mótvægi við hugmyndir sem áður voru ríkjandi um að mannlegt eðli væri syndum spillt og að Rousseau hefði pví leiðrétt viðhorf fólks til barna (Dewey, 1976-1983, 9. bindi, bls. 121). Sumar hugmyndir fyrri tíðar manna um erfðasynd tengdust harðneskjulegum viðhorfum til æskunnar.

\section{Til umhugsunar}

Leo Tolstoj var hugfanginn af boðskap Jesú pó hann væri upp á kant við rússnesku kirkjuna. Efasemdir hans um menntagildi lærdóms voru undir áhrifum frá Nýja testamentinu par sem lærisveinarnir voru, að pví er virðist, ómenntaðir alpýðumenn og sums staðar er gert fremur lítið úr lærdómi og barnaskapur jafnvel talinn mönnum til tekna par sem segir: „Hver sem tekur ekki við guðs ríki eins og barn mun aldrei inn í pað koma“ (Biblían. Lúkasarguðspjall, 18:15).

Stór hluti af andófi gegn skólum byggist á efasemdum um að peir veiti sanna menntun og geri nemendur betri. Hér er Caplan, sem frá var sagt í fjórða kafla, pó undantekning. Hann telur stóran hluta af löngu námi á háskólastigi gagnslausan fyrir atvinnulífið en afneitar hvorki gagnsemi grunnskóla né pví að lærdómur bæti líf fólks.

Á síðustu fimm áratugum hefur skólaganga lengst mjög mikið. Skyldunám hefur lengst úr átta árum í tíu og skóladögum á hverju ári hefur fjölgað. Jafnframt er fólk að meðaltali fleiri og fleiri ár í skóla eftir að skyldunámi lýkur. Hingað til hafa flestir tengt pessa aukningu við framfarir en einhvers staðar hljóta mörkin að vera.

Við purfum ekki að taka undir með peim sem vilja leggja allt skólahald niður pótt við teljum að enn fleiri kennslustundir á ári og enn fleiri ár í skóla geri líf fólks verra en ekki betra. Við getum jafnvel komist að peirri niðurstöðu að við séum komin yfir pessi mörk án pess að álykta að öll skólaganga sé gagnslaus.

a) Er pað rétt að skólar skaði börn? Er slíkt jafnvel algengt?

b) Hvað á skóladagur barna að vera langur? Hvað eiga pau að sitja margar kennslustundir í viku og hvað eiga pau að mæta í skóla margar vikur á ári? Gilda ólík svör fyrir börn á ólíkum aldri?

c) Er fólk sem hefur langa skólagöngu að baki betra en óskólagengið fólk? Reynist pað betur í vinnu? Er pað betra við börn sín og fjölskyldu? Er pað líklegra til að sýna sjálfstæði í hugsun og verki?

d) Er samband milli skólagöngu og pess hve vel fólki er treystandi til að fara með völd og stjórna fyrirtækjum, sveitarfélögum eða ríki?

e) Er réttlátt að skólaganga og prófgráđur veiti fólki forgang á vinnumarkaði, hærri laun og betri kjör?

f) Skólaganga hefur aukist undanfarna áratugi. Er ungt fólk fyrir vikið almennt betur menntað en foreldrar pess, afar og ömmur eða er pað ef til vill verr á sig komið vegna langvarandi inniveru og hreyfingarleysis?

g) Geta skáldsögur hjálpað okkur að svara spurningum um menntun og skóla? Geta pær jafnvel komið í staðinn fyrir vísindalegar rannsóknaraðferðir?

h) Hve stór hluti af menntun fólks sem skarar fram úr í pekkingu, sköpunargáfu og skilningi á tilverunni er fenginn annars staðar en í skólum?

i) Er pað rétt hjá Rousseau að öll börn fæđist óspillt en samfélagið spilli peim? Ef svo er, hvað spillir pá samfélaginu? 
j) Hvað getur barn lært af eigin reynslu án neinnar miðlunar á pekkingu sem aðrir menn hafa aflað? Ætli pað gæti til dæmis lært að rækta korn og baka brauð; rýja kind, spinna ull og prjóna sokk; telja og reikna?

k) Hvernig skyldi áhersla Rousseaus á að setja upp aðstæður par sem barn lærir af eigin reynslu koma heim og saman við pað sem Tolstoj sagði (og rætt var í priðja kafla) að kennslan ætti að gera nemanda að jafningja kennarans? 


\section{Að skrá menntun}

Til að stjórna opinberum kerfum eins og menntakerfum parf að skrá gögn með skipulegum og kerfisbundnum hætti. Yfirvöld sem stjórna íslenska skólakerfinu purfa til dæmis gögn frá Hagstofu Íslands um hvað mörg börn eru í næsta árgangi sem kemur í skóla. Til að áætla kostnað við skólahald og skipta fé milli stofnana verða líka að vera til upplýsingar um hve margir nemendur purfa sérstök úrræði eða aðstoð. Svo parf að vera á hreinu hverjir hafa lokið námi til starfsréttinda svo hægt sé að gefa út skírteini og leyfisbréf. Svona skriffinnska hefur lengi verið til og nútímasamfélag í peirri mynd sem við pekkjum er tæplega mögulegt án hennar. Pað er pó hvorki par með sagt að öll skráning gagna sé jafn pörf né að aukning hennar á síðustu árum hafi verið til góðs.

Degar ég gekk í skóla voru til samræmd próf, til dæmis barnapróf, landspróf og sveinspróf. Árangur nemenda á peim var skráður og pað var ýmisleg skriffinnska og skýrslugerð í kringum menntakerfið. Hún var pó lítil í samanburði við pað sem við nú höfum, gögnin voru dreifð um skjalaskápa og seinlegt að vinna úr peim. Nú eru gögn um hvern nemanda í grunnskólum, framhaldsskólum og háskólum skráđ í gagnagrunna sem eru orðnir hluti af hversdagslegri tilveru fólks. Margir kannast við Mentor sem heldur utan um upplýsingar um grunnskólanema, Innu fyrir framhaldsskóla og Uglu í Háskóla Íslands. Pótt gögn um námsárangur og skólagöngu teljist ekki viðkvæmar persónuupplýsingar í skilningi 3. greinar laga um persónuvernd og vinnslu persónuupplýsinga nr. 90/2018 er sumt sem hefur verið skrád um nemendur í grunnskólum og framhaldsskólum ansi nærgöngult, nánast eins og heilbrigðisupplýsingar, par sem fram kemur ýmislegt um námserfiðleika, einkunnir, forföll og fleira sem hver og einn ætti líklega að hafa sjálfræði um hvort aðrir vita.

Ef við lítum til dæmis á framhaldsskólann pá eru forföll og viðvera í kennslustundum skráð í miðlægan gagnagrunn. Í pann sama grunn er skráđur hver námsáfangi, sem nemandi tekur og tilgreint hvað hann teljist mikið nám í einingum og á hvaða hæfniprepi. Við lok áfanga er skráð einkunn og ef hún er ekki falleinkunn pá á hún að segja hvaða hæfni nemandinn hefur tileinkað sér, enda eru hæfniviðmið hvers einasta áfanga líka skráo í gagnagrunn. Sumt af pessu er fremur nýtt hér á landi, eins og skipting áfanga á hæfniprep og miðlæg skráning hæfniviðmiða. Sumt á sér sögu sem nær lengra aftur. Dannig var tekið að skrá „magn náms“'í einingum á áttunda áratug síðustu aldar pegar Menntaskólinn við Hamrahlíð tók upp áfangakerfi árið 1972 og fyrstu fjölbrautaskólarnir voru stofnaðir árið 1975.

Dað parf ekki djúpar pælingar til að átta sig á pví að svona skráning er varhugaverð af tvenns konar ástæðum. Önnur er einfaldlega sú að erfitt er að tryggja að upplýsingar sem eiga að vera trúnaðarmál leki ekki út. Hin er að töluverður hluti af gögnunum er líklegur til að gefa villandi upplýsingar. Eftir stutta umfjöllun um pessa tvenns konar skavanka skriffinnskunnar ætla ég að skýra priðja vandamálið sem er ekki alveg jafn augljóst. Dað er hvernig skriffinnskan breytir félagslegum veruleika og einfaldar hann. Hún er ekki eins og pegar einhver tekur mynd af fjalli í fjarlægð og pað stendur óbreytt eftir sem ádur. Hún er líkari pví að einhver komi með ljós og upptökuvélar inn í veislu og allir setji upp svip og hugsi meira um að koma vel út á myndinni 
en að spjalla saman og skemmta sér. Skriffinnskan hefur áhrif á hvað er gert í skólum. Um enn önnur vandamál tengd skráningu upplýsinga um menntun verður svo fjallað í næsta kafla.

\section{Fyrsta vandamál: Persónuvernd}

Við höfum um pað dæmi frá seinni árum að gögn um nemendur hafi verið aðgengileg miklu fleirum en peim sem máttu sjá pau. Frá pví sagði til dæmis í fréttum í febrúar 2019 að ýmis gögn um grunnskólanemendur sem skráð voru í Mentor hafi á tímabili verið aðgengileg öllum sem gátu skrád sig inn í kerfið, sem er stór hluti landsmanna (Jón Birgir Eiríksson, 2019).

Hliðstætt slys hefur hent Innu að minnsta kosti einu sinni. Á árinu 2016 sýndu tveir kennarar við framhaldsskóla mér að peir hefðu aðgang að gögnum sem stjórnendur skólans áttu einir að geta séð. Detta voru meðal annars námsferlar allra nemenda skólans með öllum einkunnum og vitnisburði um skólasókn. Parna mátti líka sjá grunnskólaeinkunnir og umsagnir sem grunnskólakennarar höfðu skráð um frammistöðu fólks í einstökum greinum og höfðu verið fluttar úr Mentor í Innu. Hér eru prjú dæmi um slík ummæli sem mér voru sýnd: „Ert kurteis“ 1 dönsku; „Getur gert mun betur en skilar nánast engum verkefnum“ í náttúrufræði; „Námsframvinda slök“ í leikfimi. Ennfremur gat að líta upplýsingar um fjarvistir annarra kennara við skólann úr vinnu og ástæður peirra mörg ár aftur í tímann. Sumir pessir kennarar höfðu látið af stöfum og sumir voru látnir. Ég lét stjórnanda við skólann vita af pessu, sá hafði samband við fyrirtækið sem heldur utan um Innu og lokað var fyrir lekann. Mér var sagt að hann stafaði af mistökum sem hefðu valdið pví að kennarar sem fengu aðgang að kerfinu fyrir löngu, áður en gerð var á pví einhver breyting, hefðu óvart fengið að lesa gögn sem áttu aðeins að vera aðgengileg stjórnendum.

Svona mistök við rekstur kerfa eins og Mentors og Innu eru gerð og hætt er við að einhvern tíma nái einhver að hirða og afrita í stórum stíl gögn sem eiga að vera trúnaðarmál. Jafnvel pótt við tryðum pví að pessi kerfi væru alveg örugg ættum við samt að spyrja hvaða vit sé í að upplýsingar um mætingu í kennslustundir eða frammistöðu í peim séu geymdar í gagnagrunnum sem óhjákvæmilegt er að margir hafi aðgang að. Kennari hlýtur að geta látið barn og forráðamenn pess vita hvernig pað stendur sig án pess að skrá pað í gagnagrunn og ef skóli parf að halda til haga upplýsingum um mætingu ætti hann að geta geymt pær hjá sér og fargað peim pegar nemandi hættir.

\section{Annað vandamál: Villandi upplýsingar}

Kosturinn við að skrá heiti námsgreina og einkunnir eins og gert hefur verið við grunnskóla eða heiti áfanga, einingafjölda og einkunnir eins og tíðkast við framhaldsskóla er hvað petta gefur litlar upplýsingar. Einkunnir segja til dæmis ekki annað en hvernig kennari mat úrlausnir eða verkefni. Pær tilgreina ekkert um kosti eða galla nemenda og segja hvorki hvort einhver gat betur né hvers vegna nemandi fékk pessa tölu en ekki hina.

Reyndir kennarar taka skráningu á námsárangri í tölum og magni náms í einingum væntanlega með hæfilegum fyrirvara. Dað er líka í besta falli broslegt ef einhver leggur saman annars vegar einingar sem einn nemandi fær fyrir að ljúka svo og svo mörgum áföngum í frönsku og hins vegar einingar sem annar nemandi fær fyrir að læra að temja hross og heldur að hærri summan pýði í alvöru að annar hafi lært meira en hinn. Рað er enginn einn kvarði til að mæla magn náms. Austur í Öræfi er langur vegur og Njála er löng saga en sá sem ætlar að komast að pví hvort af pessu er lengra er ósköp einfaldlega ruglaður. Рað er álíka mikil vitleysa að reyna slá máli á hvor hefur lært meira, sá sem kann að temja hest eða sá sem kann að tala frönsku.

Detta ætti svo sem að liggja í augum uppi og líka pað að tengslin milli einkunna og einingafjölda annars vegar og náms eða menntunar hins vegar eru afar losaraleg. Hugsum okkur til dæmis nemanda á síðustu önn í námi til stúdentsprófs. Hann parf að ljúka sex fimm eininga áföngum, 
alls 30 einingum, á önninni til að útskrifast. Nemandinn ætlar í hjúkrunarfræði haustið eftir og veit að pað er ráðlegt að taka efnafræðiáfangann á priðja prepi sem er í boði við skólann. Hann purfti samt að hafa mikið fyrir efnafræðinni á öđru ári og pótti hún erfið námsgrein. Efnafræðin er ekki skylda heldur val og til að vera öruggur og hafa nógan tíma til að vera í tölvuleikjum ákveður hann að sleppa efnafræðinni og skrá sig frekar í tvo valáfanga í fjarnámi sem hann nær auðveldlega pví hann kann efni peirra fyrir. Pað er líka meira öryggi í að vera í 7 áföngum, 35 einingum alls, hann hefur pá efni á að falla í einhverju. Hjá pessum nemanda stendur valið milli pess annars vegar að reyna að læra eitthvað í efnafræði, sem hann kann ekki fyrir, og fá færri einingar og hins vegar að læra minna og fá fleiri einingar.

Dæmi sem pessi, um öfugt samband lærdóms og einingafjölda, eru hvorki skrýtin né langsótt. Dau eru hversdagslegur hluti af skólagöngu margra. Meðal annars pess vegna geta gögn sem skólar skrá um nám nemenda sinna verið villandi ef pau eru skilin bókstaflega. Svoleiðis oftúlkun á sér væntanlega stað ef einhver heldur til dæmis að á bak við hverja framhaldsskólaeiningu séu ævinlega prjú dagsverk svo hægt sé að sjá af einingafjölda hvað einstakur nemandi hefur unnið mikið.

Með núgildandi aðalnámskrá var tekið að skrá hæfniviðmið fyrir allt nám og skipa pví á hæfniprep. Með pessu jókst mjög gagnamagnið um nám hvers nemanda par sem nú er ekki aðeins tilgreint að einhver hafi til dæmis fengið 6 í dönsku á fyrstu önn í framhaldsskóla. Nú hangir við petta lýsing, í löngu máli, á pví hvaða hæfni nemandi telst hafa öðlast og á hvaða prepi hún er. Vandinn er að pessi nýju og orðmörgu gögn virðast enn hæpnari en pau gömlu og knöppu.

Баð sem segir um hæfniprep í aðalnámskrá framhaldsskóla og viðmið sem par er að finna um hvernig skipa skuli áföngum á prep er vægast sagt fremur ruglingslegt. ${ }^{6.1}$. Um hæfni í tungumálum segir til dæmis að nemandi sem lokið hefur fyrsta prepi geti „tjáo sig á einfaldan hátt á erlendum tungumálum“ og sá sem hefur lokið öđru prepi geti „tjád sig á einfaldan og skýran hátt á erlendum tungumálum“ (Mennta- og menningarmálaráðuneytið, 2012, bls. 43-45). Ekki veit ég á hvaða prep menn purfa að komast til að geta tjáð sig skýrt á eigin móðurmáli en sumum tekst pað illa pótt peir hafi komist gegnum háskóla. Ég vona að enginn taki petta sem stendur í aðalnámskrá fyrir framhaldsskóla svo bókstaflega að trúa pví beinlínis að hver nemandi á fyrsta ári í framhaldsskóla sem hefur lokið öđru prepi í dönsku hljóti að geta tjáð sig á einfaldan og skýran hátt á pví máli.

Um hæfniprepin segir ennfremur í aðalnámskrá fyrir framhaldsskóla að eftir annað prep geti fólk „tjád skoðanir sínar og skýra [svo] verklag tengt skilgreindu starfsumhverfi á ábyrgan, sjálfstæðan og skýran hátt“" og að loknu pví priðja ,tjáð skoðanir sínar og skýra [svo] verklag tengt skilgreindu starfsumhverfi á ábyrgan, gagnrýninn og skýran hátt" (Mennta- og menningarmálaráðuneytið, 2012, bls. 43-45). Hér virðist munurinn á öđru og priðja prepi sá að par sem er sjálfstæði á pví öðru er gagnrýni á pví priðja. Dessi texti hjálpar okkur lítið við að henda reiður á muninum á peim sem eru stutt og peim sem eru langt komnir í námi. Sá munur er varla í raun og veru í pví fólginn að nemendur verði sjálfstæðir áður en peir verða gagnrýnir. Vonandi er sönnu nær að margir verði smám saman bæði sjálfstæðari og gagnrýnni með æ skynsamlegri hætti.

Dað sem hér hefur verið sagt um mismuninn á ólíkum hæfniprepum gildir að mestu líka um hæfniviðmið í einstökum greinum. Баð er engin leið að taka pau bókstaflega sem lýsingu á hvað nemendur geta ef peir ná lágmarkseinkunn. Gögnin um nám hvers nemanda virðast pví hafa aukist að vöxtum án pess að til yrðu traustari og betri upplýsingar. 
Gagnasöfnun yfirvalda um nemendur og skóla er ekki aðeins til nota innanlands. Hún er líka notuð til að bera saman skólakerfi ólíkra landa og slök útkoma í samanburði við önnur lönd er víða notuð sem svipa á skólakerfi eða rök fyrir breytingum á peim, en um pað verður fjallað betur í ellefta kafla. Við pekkjum petta hér á landi af umræðu um brottfall úr framhaldsskólum og litla lestrargetu nemenda undir lok grunnskóla (sjá t.d. Mennta- og menningarmálaráðuneytið, 2014).

Fullyrðingar um að unglingar hér á landi séu verr læsir en jafnaldrar í öðrum löndum byggjast æði oft á niðurstöðum PISA-prófa (e. Programme for International Student Assessment) sem eiga að mæla hvar 15 ára unglingar eru á vegi staddir í lestri, stærðfræði og raunvísindum. Dessi próf eru á vegum Efnahags- og framfarastofnunarinnar sem oftast er kölluð OECD (e. Organization for Economic Co-operation and Development) og voru fyrst lögð fyrir ́́ 32 löndum árið 2000. Síðan hafa fleiri ríki bæst í hópinn og fjöldi pátttökulanda meira en tvöfaldast (OECD, 2016). Dessi próf eru nær alls staðar lögð fyrir úrtak, eða lítinn hluta árgangs, en hér taka pau nánast heilu árgangarnir. Meðan við vitum hvorki hvort úrtökin í öðrum löndum eru raunveruleg slembiúrtök né hvað peir sem lenda í úrtaki fá mikla hvatningu til að standa sig er afar erfitt að átta sig á hvað sé mikið að marka samanburð á einkunnum. Samt er tilhneiging til að lesa útkomurnar eins og pær segi mikinn sannleika um skólakerfið. Ég held að pað sé að minnsta kosti umhugsunarefni hvort slíkur lestur er til marks um mjög góða lestrarkunnáttu.

Samanburður á menntunarstigi og brottfalli milli landa byggist í mörgum tilvikum á talnaefni frá OECD, einkum ritinu Education at a Glance sem stofnunin gefur út á hverju ári. Par hefur árum saman mátt lesa að hér á landi ljúki lægra hlutfall nemenda framhaldsskóla en í nágrannalöndum okkar. Um pað var fjallað lítið eitt í fjórða kafla.

Skyldu tölur frá ólíkum löndum um hve margir ljúka framhaldsskóla vera nothæfar til að bera saman menntun pjóðanna? Ef við skoðum til dæmis Svípjóð og Ísland pá blasir við munur á skólakerfum pessara landa sem gerir samanburð á tölum fremur hæpinn. Sænskir framhaldsskólar útskrifa alla nemendur, líka pá sem skrópa og falla á prófum. Fyrir vikið eru par gefin út stúdentsskírteini sem veita ekki heimild til að fara í háskóla. Ef hærra „menntunarstig“ Svía skýrist af pessu pá jafngildir pað varla meiri menntun. Meinið er að tölurnar einar segja okkur ekki hvort pað skýrist af pessu eða einhverju öðru. Gögn sem hafa virðulegt og vísindalegt yfirbragð eins og talnalistarnir í Education at a Glance segja stundum undarlega lítið sem mark er á takandi.

Hluti pess vanda sem hér um ræðir er að reynt er að lýsa flóknum veruleika með einni einkunn eða tölu, enda parf pess ef skipa skal einstaklingum, skólum eða skólakerfum í röð. Ef breyturnar eru tvær eða fleiri lendum við iðulega í vanda sem hægt er að skýra í stuttu máli með líkingu. Fyrir svangan maga er betra að fá tvö epli en eitt en sé spurt hvort sé betra að fá tvö epli eða eitt epli og eina appelsínu pá er tæpast hægt að gefa nákvæmara svar en að pað sé misjafnt frá manni til manns. Рað er engin ein rökrétt leið til að skipa pessum tveimur kostum í röð og ákvarða að annar sé betri en hinn.

\section{Priðja vandamál: Skráning breytir félagslegum veruleika}

Í bók um sýn yfirvalda á samfélagið (Seeing like a State), sem kom út fyrir rúmum 20 árum, fjallar bandaríski mannfræðingurinn James C. Scott (1998) um hvernig ríkið einfaldar félagslegan veruleika til að ná stjórn á honum. Mikill hluti pessarar einföldunar felst, eftir pví sem Scott segir, í kerfisbundinni skráningu. Í bókinni fjallar hann um skráningu á æettarnöfnum, búsetu, eignarhaldi á landi, tekjum og fleiru og útskýrir hvernig hún gerði skattheimtu, herkvaðningu og miðstýringu mögulega.

Sem dæmi um hvernig skráning einfaldar veruleikann má nefna að um leið og land er skráð sem eign einstaklings pá er réttur hans á að nýta pað iðulega gerður afdráttarlausari en áđur. Fyrir daga skriffinnskunnar átti nágranni kannski rétt á að nýta skóg á landinu, annar hafoi par beitarrétt, priðji mátti veiða par eða brynna hjörð sinni. Samfélög án ríkisvalds hafa iðulega flóknar hefðir um hver má nýta hvaða gæði. Með skráningu tekur réttur sem er klipptur og skorinn við af 
venjum sem gjarna eru miklu sveigjanlegri. Með skráðum eignarrétti, sem tók við af fljótandi og flóknum hefðum, var eignarhald ekki aðeins skráð svo stjórnvöld ættu auðveldara með að innheimta skatta. Skráningin bjó til mynd sem veruleikinn lagaði sig að. Mannlífið varð pví eftirlíking af myndinni fremur en að myndin líkti eftir mannlífinu. Degar opinber skrásetning á félagslegum veruleika festist í sessi fer einföldunin að gilda, menn hætta að taka mark á venjunum og fara að taka mark á pví skráđa. Sá hluti veruleikans sem ríkið „,ér"“ verður, í huga fólks, hinn sanni veruleiki, en ýmislegt sem er fyrir framan augun á pví sjálfu fals og dár.

Skráning á „magni“ framhaldsskólanáms í einingum, sem hófst á áttunda áratug síðustu aldar, er gott dæmi um petta sem Scott lýsir. Skráningin var meðal annars til pess að ríkið gæti metið „afköst“ skóla og notað slíkt mat til að skipta peningum milli peirra. Dessi skráning fór fremur fljótt að hafa töluverð áhrif á hvernig almenningur hugsaði um menntun. Dað sem ég man og hef reynt pykir mér benda til að pessi áhrif hafi aukist verulega pegar tekið var að skrá einingar við ríkisrekna framhaldsskóla í Innu fljótlega eftir aldamót.

Á árunum 2001 til 2011 var ég aðstoðarskólameistari við framhaldsskóla og sinnti meðal annars ýmsum erindum frá fyrrverandi nemendum skólans. Margir peirra purftu að fá staðfestingu á pví að peir hefðu lokið svo og svo miklu námi. Á seinni hluta pessa tímabils var fólki í vaxandi mæli beint 1 raunfærnimat sem stytti leiðina sem pað purfti að fara til að ljúka starfsnámi. Í tengslum við petta purfti allmargt fullorðið fólk að fá upplýsingar um hvað pað hefði lokið mörgum framhaldsskólaeiningum, til dæmis í dönsku, á sínum unglingsárum. Fyrir suma skipti talsverðu máli hvað einingarnar voru margar pví tilskilinn fjöldi var forsenda fyrir brautskráningu af iðnog starfsmenntabrautum.

Allir sem ég talaði við virtust líta á pað sem sjálfsagðan hlut að hægt væri að tilgreina, með tölum, magn dönskunáms fyrir tuttugu árum síðan. Hins vegar var allt kerfið sett pannig upp að pað gat ekki skipt nokkru einasta máli hvort peir sem báðu um pessi plögg gæetu lesið eða talað dönsku. Рað var skráningin sem gilti en ekki veruleikinn sem skráningin átti upphaflega að vera til vitnis um. Veruleikinn sem ríkið „sá“ var farinn að skipta meira máli en pað hvað fólk gat og kunni.

Fleiri fræðimenn en Scott fjölluðu um svipað efni á árunum rétt fyrir aldamót. Í grein um eftirlit með breskum háskólum lýsti Marilyn Strathern mannfræðingur við Cambridge-háskóla pví til dæmis hvernig „,eftirlitið gat ekki séð hvernig Cambridge-háskóli virkaði“ pví skriffinnskan var bundin við tilteknar gerðir af stöðluðum vísbendingum sem náðu engan veginn að lýsa raunverulegu starfi (Strathern, 1997, bls. 312).

Nær öll skýrslutækni stjórnvalda er hugsuð út frá stöðluðum vísbendingum. Hún er í vaxandi mæli notuð til að slá máli á „,afköst“ og „gæði“ skóla og „,menntunarstig“ pjóða. Einingar, lýsingar á hæfniviðmiðum og einkunnir eru svona vísbendingar. Til að átta okkur á hvernig pær einfalda veruleikann held ég að gott sé að hafa í huga greinarmun sem Ivan Illich (1995) gerði (sá sami og nefndur var í síđasta kafla sem andófsmaður gegn skólahaldi). Í síðustu köflum bókar sinnar um afskólun samfélagsins segir hann að skólakerfið snúist mest um væntingar en viðleitni til menntunar hljóti einkum að styðjast við vonir.

Við getum nýtt pennan greinarmun á vonum og væntingum óháð pví hvort við sampykkjum kenningar Illich að öðru leyti. Dað er hægt að skilja hvað greinarmunurinn pýðir með pví að hugsa um hversdagsleg dæmi um nám og kennslu. Ökukennari ventir pess til dæmis að nemandi pekki umferðarmerkin. Á bílprófi er svo kannski kannað hvort ökuneminn rís undir pessum væntingum. Væntingarnar eru pað sem við ætlumst til að neminn standi skil á, heimtum að hann klári. Vonin á pó líka sinn sess í formlegu námi eins og ökunámi par sem kennarinn reynir að temja nemanda sínum gætni og tillitssemi. Hann getur pó tæpast gert eiginlegar kröfur í peim efnum. Detta er meðal annars vegna pess að hver sem er getur póst vera gætinn og tillitssamur í smá stund meðan hann tekur bílpróf, en pað er engin leið að svara eins og maður pekki umferðarmerkin án pess að pekkja pau í raun og veru. Kennarinn verður að láta sér duga að vona að boðskapur sinn um gætni og tillitssemi hafi áhrif. 
Ef verið er að kenna eitthvert námsefni eins og kannski Brennu-Njáls sögu er hægt að ætlast til að nemendur leggi staðreyndir á minnið og svari pví rétt á prófi að Hildigunnur giftist Höskuldi og Hallgerður var tengdamóðir Dráins, en kennsla í Njálu sem snýst aðeins um væntingar sem hægt er fara fram á að nemendur standi skil á verður sennilega ansi leiðinleg. Sagan er hins vegar áhugaverð ef fólk reynir til dæmis að skilja samskipti karla og kvenna í henni, eða Kelta og norrænna manna. Slík viðleitni til skilnings er opin og henni lýkur ekki. Jafnvel pó fólk hafi skoðað söguna með hliðsjón af öðrum miðaldabókmenntum og alls konar vísindum og lesið hana aftur og aftur er pað enn að leita skilnings.

Hefðbundin kennsla flestra greina býr yfir flóknu samspili vona og væntinga, markmiða sem hægt er að ljúka og viðleitni sem stýrir námi og kennslu án pess að neitt vit sé í að tala um að hún klárist eins og nánar verður skýrt í tíunda kafla. Skráning á námi einfaldar pennan veruleika og einföldunin veldur pví að væntingarnar verða í fyrirrúmi en vonirnar víkja.

Рað sem hægt er að klára er skráð en annað ekki. Рað sem telst með er pví einungis helftin af náminu - og raunar ekki einu sinni pessi helft pví pað sem er skráð er einatt aðeins vísbendingar um nám - eitthvað á borð við einingar og einkunnir. Stundum er pað sem hægt er að gera kröfur um að allir klári svo lítið að nemandi sem kominn er í framhaldsskóla eða háskóla getur gramsað pað til sín í fjarnámi með pví að sitja við tölvuskjá í fáeinar stundir eða renna yfir glærur og glósur rétt fyrir próf. Hann fær einingar eins og peir sem taka pátt í samræðum, leit og pælingum vegna pess að skráningin telur ekki viðleitni sem stýrist af tilgangi af pví tagi sem Illich tengdi við vonir fremur en væntingar.

Í margvíslegu námi er pað sem raunhæft er að krefjast af heilum hópi eða bekk og vænta má að allir standi skil á í lok misseris eða skólaárs ósköp lítið í samanburði við pað sem er skynsamlegt að vona að fólk fái út úr pví að taka pátt í skólastarfinu af lífi og sál. Af pessu leiðir að ef væntingarnar einar teljast skipta máli pá virðist lítil ástæða til að taka raunverulegan pátt í neinu lærdóms- eða skólasamfélagi.

Рað er athyglisvert í pessu sambandi að í allmörgum handbókum um námskrárgerð er mælt eindregið gegn pví að tilgreina hæfniviðmið eða námsmarkmið sem er ekki hægt að ljúka og ganga úr skugga um að hafi verið lokið (sjá t.d. Kellough og Kellough, 2007; Marzano og Kendall, 2008). Vonin er ekki aðeins hornreka. Hún er beinlínis skilgreind sem villa.

\section{Til umhugsunar}

Góð kennsla getur fært nemendum margt sem hæpið er að mæla og skrá sem árangur. Hún getur til dæmis fært peim undrun frammi fyrir leyndardómum tilverunnar og löngun til að læra meira. Undrun og löngun til að læra virðast samt ekki tilheyra neinu hæfniprepi og ef við hugsum um námseiningu í framhaldsskóla og háskóla sem priggja daga vinnu er nánast hlægilegt að meta undrun og löngun til eininga.

a) Hvaða upplýsingar purfa skólar að skrá um nemendur?

b) Hvað af pessum upplýsingum parf að vera í gagnagrunnum sem fólk utan skólans hefur aðgang að?

c) Er hægt að meta hvað tekur „venjulegan“ nemanda langan tíma að læra að temja hest; synda bringusund; tala dönsku; pátta annars stigs margliðu; átta sig á að sælla er að gefa en piggja?

d) Hvernig getum við borið saman skólakerfi í tveimur löndum og komist að pví hvort sé betra?

e) Hvað fleira en pað sem nefnt er í kaflanum er hægt að nota sem dæmi til að skýra mis muninn á vonum og væntingum? 


\section{Vandi gagnadrifinnar stjórnsýslu}

Á Kjalarnesi er hraðamyndavél við pjóðveginn. Ef tölurnar sem hún skráir skiptu engu máli fyrir ökumenn pá væri hægt að nota hana til að afla upplýsinga um umferðarhraða á veginum, en vegna pess að tölurnar sem hún skráir skipta máli - fólk fær sekt ef pað ekur yfir löglegum hraða - er myndavélin ónothæf til að safna gögnum um hve hratt er ekið svona almennt og yfirleitt. Flestir sem aka veginn vita af myndavélinni og pað er afar sennilegt að margir hægi á sér pegar peir koma að henni.

Detta dæmi fellur undir reglu sem er stundum kennd við enska hagfræðinginn Charles A. E. Goodhart og kölluð lögmál Goodharts. Hann segist sjálfur hafa sett regluna fram í hálfkæringi á ráđstefnu á vegum seðlabanka Ástralíu sem haldin var í Sydney árið 1975. Hugsunina að baki henni segir hann vera að pegar breytt er um stjórntæki pá breytist hegðun peirra sem er stjórnað (Goodhart, 2015). Reglan er líka stundum eignuð bandarískum hugsuði sem hét Donald T. Campbell og fjallaði jöfnum höndum um heimspeki, sálfræði og ýmsar greinar félagsvísinda. Hann orðaði sömu hugmynd um svipað leyti og sagði að bví meira sem töluleg gögn væru notuð sem stjórntæki pví bjagaðri yrðu pau og spilltu um leið peim félagslega veruleika sem peim væri ætlað að lýsa (Campbell, 1976).

Með svolítilli einföldun má segja að lögmál Goodharts pýði að pegar mæling er notuð sem stjórntæki, til dæmis til að ákvarða kjör fólks, verði niðurstöður hennar lítið að marka. Dessi regla er orðuð á ýmsa vegu. Meðal fræðimanna sem fjalla um menntun og skóla er framsetning Marilyn Strathern (1997), sem nefnd var í síðasta kafla, líklega pekktust. Hún orðaði regluna á pá leið að pegar niðurstaða mælingar yrði keppikefli pá hætti mælingin að vera góð mæling.

Раð parf ekki að horfa lengi í kringum sig til að sjá dæmi um hvernig gögn bjagast vegna pess að pau skipta máli. Í Morgunblaðinu 18. apríl 2018 var pað til dæmis haft eftir bæklunarlækni að pað væri sex til átta mánaða bið eftir pví einu að komast á biðlista eftir liðskiptaaðgerð (Ingveldur Geirsdóttir, 2018). Ef petta var rétt pá biðu mun fleiri en voru skráđir á biðlista. Ef einhverjir, sem höfðu völd í heilbrigðiskerfinu, gátu hnikað pví til hvað fólk beið lengi í óskrásettri biðröð áđur en pað komst í skrásettu biðröðina, pá var ekkert að marka opinberar tölur um hve margir biðu.

Í reynd pýðir lögmál Goodharts að stjórnsýslugögn séu annars eðlis en rannsóknargögn. Dau fyrrnefndu eru iðulega notuð til að taka ákvarðanir sem skipta máli fyrir fólk og pess vegna finnur fólk leiðir til að hnika peim sér í vil. Stjórnvöld bregðast stundum við með pví að reyna að safna meiri og ítarlegri gögnum og pá fer stundum í gang vítahringur par sem skriffinnska og eftirlit vaxa úr hófi fram. Um petta er fjallað í bók eftir bandaríska sagnfræðinginn Jerry $Z$. Muller (2018). Í bókinni gagnrýnir Muller pað sem hann kallar mælingaáráttu og lýsir ýmsum slæmum afleiðingum pess að láta staðlaðar árangursmælingar koma í staðinn fyrir dómgreind og persónulegt mat byggt á reynslu.

Í inngangi bókarinnar reifar Muller tilefni skrifa sinna, sem er að nú til dags hafa margir trú á gagnsæi, stöðluðu mati og árangurstengingum af ýmsu tagi. Eitt af helstu einkennum pessa pankagangs segir hann vera skoðanir í pá veru að besta leiðin til að drífa fólk áfram í vinnu sé að 
láta kjör pess velta á pví hvernig frammistaða pess mælist par sem mælingin er hlutlæg og stöðluð og skilar samanburðarhæfum gögnum. Muller útilokar ekki að hugsun af pessu tagi eigi við í vissum tilvikum par sem starfsemi hefur aðeins eitt hlutverk og hægt er að mæla hve vel pví er sinnt, en stofnanirnar sem hann fjallar mest um, eins og lögregla, spítalar og skólar, hafa í raun mörg hlutverk. Sumt sem pær eiga að gera er hægt að mæla með góðu móti en annað síður. Umræddur pankagangur verður pá til pess að áherslan færist á pað mælanlega, en hitt fer forgörðum. Einnig gerist pað jafnan að peir sem eiga hagsmuna að gæta nota vit sitt og krafta til að skekkja mælitölur sér í vil í stað pess að sinna skjólstæðingum.

Dæmin sem Muller tekur um petta eru býsna mörg: Eitt er um skurðlækna sem viku sér undan að sinna sjúklingum sem mjög tvísýnt var um vegna pess að kjör læknanna ultu á pví hve stór hluti aðgerða hjá peim heppnaðist. Af pessu leiddi að peir sem mest purftu á læknishjálp að halda áttu erfiðast með að fá hana. Sum eru um skóla sem náðu betri niðurstöðum úr samræmdum prófum með hreinu og kláru svindli eða með bví að fá nemendur sem voru líklegir til að fá lága einkunn til að vera fjarverandi á prófdag eða flokka pá sem fatlaða svo peir væru löglega undanpegnir. Önnur eru um lögregluumdæmi sem létu lík liggja í yfirgefnum húsum fremur en að hækka tölu óleystra morðmála.

Um öll pessi ósköp bætir Muller pví við að árangursmælingar séu í mörgum tilvikum dýr starfsemi og tími og peningar sem fari í pær geti nýst til parfari verka. Að hans mati gera peir sem leggja ofuráherslu á árangursmælingar að mörgu leyti sömu mistökin og einkenndu hagstjórn í Sovétríkjunum sálugu. Par var reynt að stjórna öllu með pví að setja mælanleg markmið og pvinga fram ,árangur“ sem varð tölum talinn.

Eins og góðum sagnfræðingi sæmir rekur Muller sögu pessarar mælingaáráttu og segir til dæmis frá tilraunum til að tengja opinber framlög til skóla við mældan árangur sem gerðar voru á Englandi pegar á nítjándu öld. Slík viðleitni reis og hné fram eftir tuttugustu öldinni en í aldarlok náði hún, segir hann, nýjum hæðum og hefur síst rénað síðan.

\section{Lögmál Goodharts og „,afköst““ íslenskra framhaldsskóla}

Skyldi lögmál Goodharts gilda um gögn sem yfirvöld hér á landi nota til að stjórna skólum? Svolítil athugun sem ég gerði á upplýsingum sem liggja frammi á vef Hagstofu Íslands um fjölda brautskráđra stúdenta á árabilinu frá 1995 til 2011 virðist benda til pess. Hún gefur að minnsta kosti tilefni til að skoða málið nánar. Рað verða pó einhverjir að gera sem hafa betra vald á tölfræðilegum aðferðum en ég.

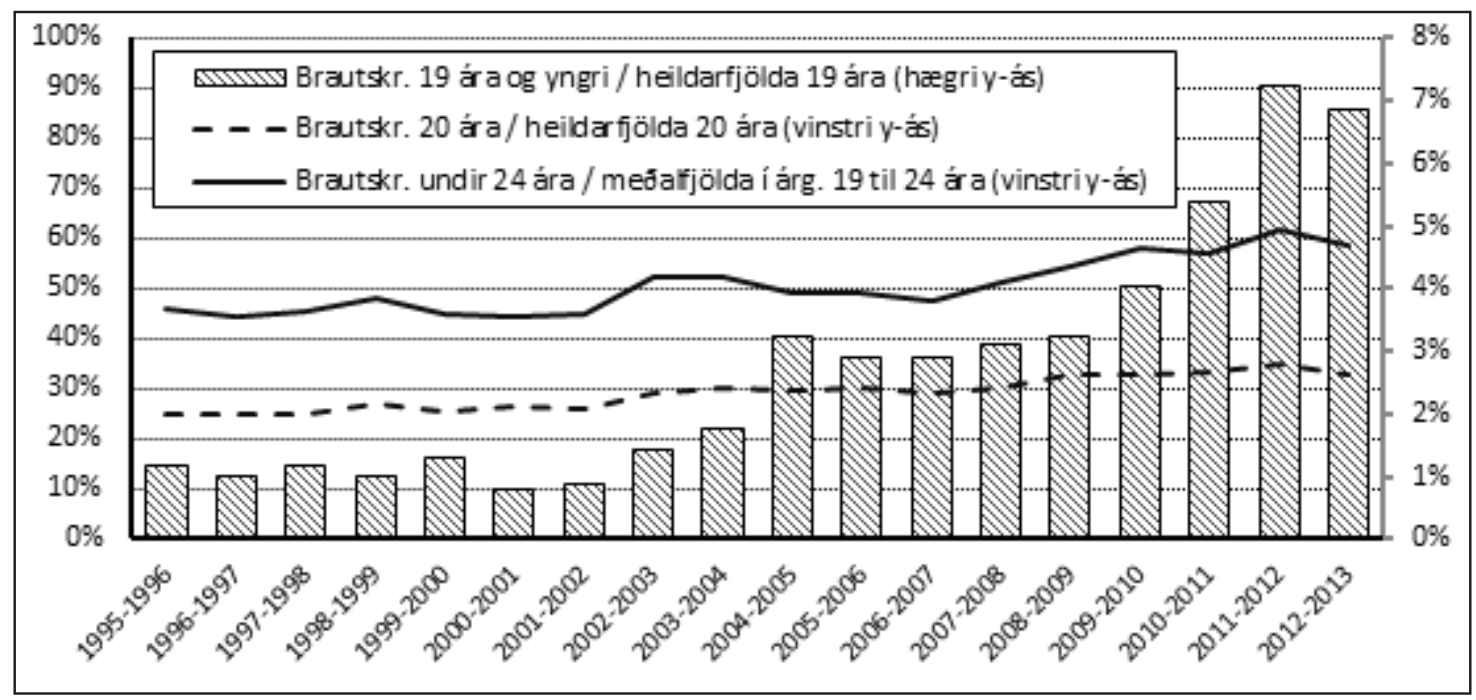

Mynd 7.1. Fjöldi brautskráđra stúdenta sem hlutfall af fjölda í árgangi 
Myndin sýnir fjölda brautskráðra stúdenta úr íslenskum framhaldsskólum sem hlutfall af fjölda 1 árgangi. Gögn sem myndin byggist á voru sótt af vef Hagstofu Íslands. Aldur í árum er aldur við næstu áramót eftir brautskráningu. Súlurnar sýna hve stór hundraðshluti árgangs lauk stúdentsprófi fyrir tvítugt. Slitrótta línan sýnir hve stór hluti lauk stúdentsprófi 20 ára og óbrotna línan hve stór hluti lauk pví fyrir 24 ára aldur. Af pessari mynd má lesa vísbendingu um að lögmál Goodharts sé að verki og í næstu efnisgreinum reyni ég að skýra hvers vegna.

Á stórum hluta pessa tímabils sem myndin sýnir einkenndist stefna stjórnvalda um málefni framhaldsskóla af viðleitni til að vinna gegn brottfalli. Dessi viðleitni er gott dæmi um opinbera stefnumótun sem reynt var að framkvæma með hjálp skráningar á stöðluðum gögnum pví talning eininga var lykilatriði í framkvæmd stefnunnar. Með henni gátu stjórnvöld notað reikniformúlu til að úthluta fé til skóla. Dessi formúla er kölluð reiknilíkan til að reikna út kennslukostnað framhaldsskóla. Баð var fyrst kynnt fyrir skólastjórnendum 1998 og pví var formlega komið á laggirnar með reglugerð nr. 335/1999.

Ólafur Sigurðsson (2008), fyrrum skólameistari og síðan sérfræðingur hjá Mennta- og menningarmálaráđuneytinu, hefur gert ágæeta grein fyrir tilurð og próun reiknilíkansins. Samkvæmt pví sem hann segir var pað í fyrsta sinn notað við fjárlagagerð árið 1998. Рað var svo endurskoðað í byrjun pessarar aldar og 2003 fékk pað á sig pá mynd sem pað hefur lengst af haft.

Reiknilíkanið metur afköst skóla í námseiningum. Dær eru sú afurð skólanna sem ríkið „sér“. Í stuttu máli er reiknilíkanið regla sem segir að ríkið úthluti fé til skóla í hlutfalli við fjölda námseininga sem nemendur fá einkunnir fyrir. Баð flækir svo málin ofurlítið að borgað er mismikið fyrir hverja einingu, meðal annars eftir pví hvort hún er í verklegri eða bóklegri námsgrein.

Ĺ́kaninu var í senn ætlað að vera sanngjörn leið til að skipta peningum milli framhaldsskólanna og að vera tæki stjórnvalda til að vinna gegn brottfalli. Petta kom meðal annars fram í ummælum ráðherra. Dann 20. október 2004 svaraði páverandi menntamálaráðherra, Dorgerður Katrín Gunnarsdóttir, til dæmis fyrirspurn Björgvins G. Sigurðssonar alpingismanns, um hvort til stæði að grípa til sérstakra aðgerða til að minnka brottfall úr framhaldsskólum, og sagði:

Með reiknilíkani og samningum við skóla um árangursstjórnun hefur frá árinu 1998 verið unnið gegn brottfalli í framhaldsskólum. Hafa fjárveitingar til framhaldsskóla frá pessum tíma miðast við pann fjölda nemenda sem preytir próf og fjölda preyttra eininga [...] Í pessu kerfi er pví innbyggður hvati fyrir framhaldsskóla til að vinna gegn brottfalli par sem fjárveitingar eru háđar pví hve vel gengur að halda nemendum við nám í skóla. (Dorgerður Katrín Gunnarsdóttir, 2004)

Svar Porgerðar Katrínar virðist rökrétt og að ýmsu leyti dæmigert fyrir opinbera stefnumótun. Ef ég skil pað rétt er hugsunin eitthvað á pessa leið:

a) a)Ríkið setur markmið (í pessu tilviki að fleiri klári nám í framhaldsskóla);

a) b)Skilgreinir leið til að mæla vísbendingar um árangur;

a) c)Umbunar stofnunum (b.e. veitir fé til peirra) eftir pví hvað kemur út úr mælingunum.

Ef við gerum ráð fyrir að allir nemendur séu í fullu námi, hvorki meira né minna, pá getur skóli lítið gert, eftir að innritun er lokið, til að hámarka einingafjölda á ári annað en að fá nemendur til að tolla fram yfir lokapróf. Að pessu gefnu hlaut reiknilíkanið að hvetja skóla til að koma í veg fyrir að nemendur hættu á miðri önn.

Fyrstu árin eftir að reiknilíkanið var tekið í notkun urðu samt engar verulegar breytingar á gegnumstreymi nemenda um stúdentsbrautir. Deim fjölgaði dálítið og urðu hærra hlutfall af árgangi en pað breyttist ekkert mikið. Фað tókst ekki vel að hemja brottfallið, að minnsta kosti ekki af námsbrautum til stúdentsprófs. Mun flóknara er að henda reiður á gegnumstreymi nemenda um 
aðrar námsbrautir framhaldsskóla, einkum iðnbrautir par sem hluti námsins fer fram á vinnustöðum án pess nemendur séu skráðir í skóla á meðan. Dess vegna held ég mig við að ræða um stúdentsnámið.

Samkvæmt tölulegum gögnum á vef Hagstofu Íslands hækkaði hlutfall sextán ára unglinga sem hófu nám í framhaldsskóla jafnt og pétt, úr 89\% af árgangi haustið 1999 í 94\% af árgangi haustið 2005. Allan pennan tíma voru peir sem luku stúdentsprófi fjórum árum eftir lok grunnskóla rétt rúmur priðjungur af peim sem hófu nám í framhaldsskóla sextán ára. Við sjáum á myndinni nokkra aukningu í hlutfalli stúdenta, einkum peirra sem kláruðu fyrir 24 ára aldur, bæði frá 2002 til 2003 og eftir 2008. Рað er pó hæpið að bera árin eftir 2008 saman við árin á undan pví haustið 2008 og næstu misseri par á eftir var kreppa í efnahagslífinu og talsvert erfiðara fyrir unglinga að fá vinnu en verið hafði.

Skólaárið 2002 til 2003, og næstu ár par á eftir, gerðist nokkuð annað sem er áhugavert. Peim sem útskrifuðust með stúdentspróf minna en fjórum árum eftir lok grunnskóla fjölgaði. Á premur árum tók hlutfall peirra sem brautskráđust 19 ára eða yngri stökk frá pví að vera um 1\% af árgangi upp í um 3\% af árgangi. Detta sýna súlurnar á myndinni sem eru fengnar með pví að deila fjölda 19 ára landsmanna í fjölda sem lauk stúdentsprófi 19 ára eða yngri, enda geri ég ráð fyrir að peir sem útskrifuðust 18 ára eða yngri hafi verið sárafáir og pessir ungu stúdentar hafi nær allir verið 19 ára í lok ársins sem peir brautskráđust.

Рað var ekki verið að stytta stúdentsnám á pessum tíma. Pað var heldur engin fjölgun í hópi peirra sem hlupu yfir ár í grunnskóla og byrjuðu í framhaldsskóla árið sem peir urðu 15 ára. Bekkjaskólarnir voru áfram sömu fjórir bekkirnir í röð. Hvað var að gerast? Hvers vegna varð pessi skrýtna preföldun? Ég held að svarið sé, í stuttu máli, að með tilkomu reiknilíkansins borgaði sig fyrir skóla að „,framleiða“ sem flestar einingar. Á uppgangstímum, pegar atvinnulífið togaði í ungt fólk, var erfitt að fá alla til að tolla í skóla. Hins vegar var mun auðveldara að fá pá sem ekki var neitt fararsnið á til að taka ögn fleiri einingar á önn. Hvort tveggja var jafn hagkvæmt fyrir skólana: 18 nemendur sem tóku 20 einingar hver skiluðu jafnmiklu fé og 20 nemendur sem tóku 18 einingar hver. Áður hafði dæmigerð önn verið 17 til 18 einingar og hér er átt við einingar af eldri gerðinni sem var aflögð með gildistöku nýrrar aðalnámskrár 2011. Námsárið var á pessum tíma hugsað sem 35 einingar og stúdentsprófið 8 × 171/2=4 x $35=140$ einingar.

Í kringum 2004, pegar endurskoðað reiknilíkan var farið að virka, færðist einingafjöldi á önn sem sagt aðeins upp á við, að minnsta kosti hjá hluta nemendahópsins. Við skóla par sem ég pekki til tóku margir 18 til 19 einingar og allnokkur hópur 20 einingar á önn eða meira. Deir sem kláruðu 20 einingar á önn, 7 annir í röð, luku stúdentsprófi á premur og hálfu ári. Deir voru pví aðeins 19 ára í lok útskriftarárs en ekki 20 ára eins og jafnaldrar peirra sem brautskráđust vorið eftir. Skólar gerðu nemendum mögulegt að taka fleiri einingar á önn meðal annars með pví að leyfa peim sem voru með fulla stundatöflu að bæta við hana stökum áföngum í fjarnámi. Sumir löðuðu til sín nemendur úr öðrum skólum sem tóku pá kannski fullt nám, 18 einingar, í heimaskóla og einn eða tvo áfanga að auki í fjarnámi við annan skóla. Dað hvað fjarnámið var mikið auglýst í fjölmiðlum bendir til að töluverð samkeppni hafi verið milli skóla um að „selja“ sem flestar einingar.

Dularfulla trappan á súlunum skýrist væntanlega af pessu. Einingum á hvern nemanda sem tolldi í skóla fjölgaði að jafnaði og pað ýtti dágóðum hóp upp í 20 einingar á önn að meðaltali með peim afleiðingum að fleiri brautskráðust 19 ára.

Tilraun ríkisins til að auka „afköst“ framhaldsskóla hafði áhrif en áhrifin voru önnur en að var stefnt. Aukin „afköst“ skólanna drógu lítið úr brottfalli úr stúdentsnámi en fjölguðu skráðum námseiningum, par sem nemendur sem héldust í skóla luku að meðaltali fleiri einingum á önn. Töluleg gögn um fjölda eininga sem áttu að segja hve vel skólum gekk að vinna gegn brottfalli gáfu misvísandi upplýsingar vegna pess að pau skiptu máli, pað voru hagsmunir í húfi. Með orðalagi Marilyn Strathern má segja að par sem niðurstöður mælinganna urðu keppikefli skóla hættu 
pær að vera góðar mælingar. Баð varð einhvers konar verðbólga í einingahagkerfinu. Fjölgun eininga átti að jafngilda pví að fleiri nemendur héldu áfram í námi, en gerði pað ekki, vegna pess að skólarnir gátu hnikað útkomu talningar og mælinga til með öðrum aðferðum en að draga úr brottfallinu.

\section{Vantraust og vítahringur}

Eins og margir fræðimenn hafa fjallað um hangir eftirlitsiðnaður og oftrú á árangursmælingum í menntakerfinu iðulega saman við vantraust á pekkingu fólks á vettvangi (Brien, 1998; Codd, 1999, 2005; Lowe, 2007; Fitzgerald, 2009; Winstanley, 2012; Goldstein, 2014; Lingard, Martino, Rezai-Rashti og Sellar, 2016). Í merku riti um afdrif framstefnu í enska skólakerfinu segir Roy Lowe (2007) til dæmis að pegar nálgaðist lok síðustu aldar hafi reglugerðir og opinber stefnumótun orðið að faraldri og yfirvöld hafi hætt að treysta kennurum til að nota eigið vit og fagpekkingu til að stjórna störfum sínum. Dana Goldstein (2014), sem fjallar um svipaða raunasögu bandarískra skóla, talar um mælingasvall sem hafði pær fyrirsjáanlegu afleiðingar að sífellt minna var að marka mælingar á árangri og afköstum skóla. John Codd $(1999,2005)$ segir sömu sögu frá Nýja Sjálandi, par sem tilraunir til að knýja fram umbætur með pví að mæla vísbendingar um árangur skóla grófu undan fagmennsku kennara. Aðrir fræðimenn hafa rökstutt að pað sem gildir um Bretland, Bandaríkin og Nýja Sjáland eigi líka við annars staðar. Pessi pankagangur ali á vantrausti og komi í veg fyrir að pekking og reynsla á vettvangi nýtist (Lingard o.fl., 2016).

Muller (2018) fjallar um petta með víðara sjónarhorni en peir sem einblína á menntakerfið par sem hann skoðar margar greinar opinbers rekstrar. Niðurstaða hans er að pví minna sem fólk treystir hvert öðru pví háværari sé krafan um árangursmælingar og skriffinnsku sem fylgir. Úr verður, segir hann, vítahringur par sem vantraust kallar á eftirlit og eftirlitið elur á vantrausti.

Í bók sinni um almannavettvanginn og vandamál hans (The Public and its Problems), sem upphaflega kom út árið 1927, ræðir John Dewey (1981-1990, 2. bindi, bls. 235-372) um pörf lýðræðislegs samfélags fyrir bekkingu allra, líka reynslupekkingu almennings. Dewey skýrir mál sitt með líkingu, par sem hann segir, að pó sérfræðingur í skósmíði viti kannski meira um skó en við hin, viti ég samt betur en hann hvar minn eigin skór kreppir. Með pessari sömu líkingu má segja að pví meira sem opinber stefnumótun snýst um pann hluta veruleikans sem ríkið „sér“ pað er að segja stöðluð og samanburðarhæf gögn - pví minna sé hugað að hvar skórinn kreppir. Áherslan færist á viðleitni til að keyra upp mælistærðir og hin síðustu ár einkum pær sem hægt er að nota til að bera saman menntakerfi margra landa. Muller (2018) fjallar um pennan sama vanda í bók sinni og sækir svipaða hugsun og finna má hjá Dewey til fjölfræðingsins Michaels Polanyi, heimspekingsins Michaels Oakeshott og hagfræðingsins Friedrichs von Hayek. Dessir premenningar gerðu allir greinarmun á almennri vitneskju sem hægt er að setja fram sem reglur, töflur og töluleg gögn, og pekkingu á pví einstaka og staðbundna sem menn afla með reynslu og er samofin tilfinningu og skynjun pess sem er kunnugur vettvangi. Hann segir að eftirlitsiðnaðurinn hunsi iðulega pekkingu af seinni gerðinni og komi í veg fyrir að hún sé notuð sem skyldi. Detta segir hann að sé afar skaðlegt fyrir margs konar opinbera pjónustu.

\section{Til umhugsunar}

Stundum er mótuð opinber stefna par sem mælingar á árangri eru hvorki skilgreindar né látnar hafa neinar afleiðingar. Stundum virðist slík stefnumótun aðeins falleg orð sem ekki hafa nein raunveruleg áhrif. Sé hins vegar reynt að nota mælanleg markmið og árangurstengingar er hættan sú að fólk á vettvangi eyði kröftunum í að hnika upp mælistærðum í stað pess að sinna pví sem parfast er að gera á hverjum stað og hverri stund. Degar mælikvarðarnir verða í pokkabót skakkir og bjagaðir og gefa villandi vísbendingar pá er hætt við að stofnanir á borð við skóla geri minna gagn en pær myndu gera ef fólk á vettvangi færi einfaldlega sínu fram án neinnar stefnumótunar að ofan. 
Í báðum tilvikum vantar stefnumótun yfirvalda jarðsamband. Í fyrra tilvikinu virkar hún lítt eða ekki og í pví seinna meira og minna á annan hátt en til var ætlast. Detta vekur spurningar um hvort og hvernig sé hægt að móta pólitíska stefnu og fylgja henni eftir.

a) Hvernig geta ríki og sveitarfélög úthlutað peningum til skóla með réttlátum hætti?

b) Er hægt að mæla afköst eða árangur skóla án pess að gagnasöfnunin hafi óæskileg áhrif eins og lýst var í sjötta kafla og án pess hagsmunir brengli gögnin eins og lýst hefur verið í pessum kafla?

c) Hefur gagnasöfnun yfirvalda sams konar áhrif á íslenska skóla og lýst er undir fyrirsögninni Vantraust og vítahringur?

d) Darf að hafa eftirlit með skólum? 


\section{Skrifræði og einkavæðing}

Ef stjórnvöld ætla að skipta fé milli stofnana með sanngjörnum hætti og fylgjast með pví að pær gegni hlutverkum sínum purfa pau að styðjast við samanburðarhæf gögn. Vandinn við stjórnsýslu sem reiðir sig á staðlaðar upplýsingar er að minnsta kosti tvenns konar. Annars vegar eru gögnin aðeins vísbendingar og ná aðeins utan um hluta af pví sem máli skiptir eins og rakið var í sjötta kafla. Hins vegar hættir peim til að verða pví ótraustri pví meira sem reynt er að nota pau til að ákvarða kjör fólks, eins og rakið var í sjöunda kafla.

Undanfarna áratugi hafa stjórnvöld víða um heim reynt að mæta stjórnunarvanda opinberra kerfa, bæði með einkavæðingu og með svokallaðri nýskipan í opinberum rekstri (e. new public management) par sem reynt er að láta rekstur almannabjónustu, sem ríki eða sveitarfélög annast, líkja eftir aðstæðum á samkeppnismarkaði. Báðar pessar leiðir tengjast hugmyndum í pá veru að samkeppni milli stofnana knýi pær til að standa sig vel og geti að nokkru komið í staðinn fyrir opinbert eftirlit. Dær eru báðar afsprengi breytinga sem urðu í stjórnmálum víða um heim á árunum um og fyrir 1980. Pá varð til nokkuð víðtækt samkomulag stjórnmálaflokka í mörgum löndum um að greiða fyrir markaðsbúskap og alpjóðavæðingu í efnahagslífi. Megnið af litrófi stjórnmálanna, frá frjálslyndum borgaraflokkum hægra megin við miðju til jafnaðarmannaflokka á vinstri vængnum, sameinaðist um pessa stefnu. Í mörgum Evrópulöndum var hún fest í sessi með Maastricht-sáttmálanum árið 1992 pegar Efnahagsbandalag Evrópu breyttist í Evrópusambandið.

Nýskipan í opinberum rekstri varð opinber stefna á Íslandi um miðjan tíunda áratug síðustu aldar (Fjármálaráðuneytið, 1996) og síðan pá hefur að minnsta kosti átt að heita að framhaldsskólar og háskólar, og sums staðar líka leik- og grunnskólar, kepptu hver við annan á einhvers konar markaði. Berglind Rós Magnúsdóttir hefur lýst áhrifum pessarar stefnu sem neytenda- og vöruvæðingu í menntakerfinu ,par sem hugmyndin er að tryggja megi gæði menntunar með samkeppni og vali (milli skóla, kennara, nemenda, námsefnisútgefenda)“ (Berglind Rós Magnúsdóttir, 2013, bls. 57).

Skyldi pessi áhersla á samkeppni, sem margir kenna við nýfrjálshyggju, í raun og veru hafa leyst stjórnunarvandann sem ég hef reynt að lýsa? Skriffinnska virðist ekki hafa minnkað. Eins og ég rakti í sjötta kafla hefur gagnasöfnun hins opinbera um nám og skólastarf pvert á móti aukist á síðustu áratugum. Svipaða sögu er að segja frá öðrum löndum sem tekið hafa upp stefnu í æett við nýskipan í opinberum rekstri. Gagnrýna og afar skemmtilega umfjöllun um pað má til dæmis finna í bók eftir bandaríska mannfræðinginn David Graeber (2015) sem segir að markaðsvæðingu að tilhlutan stjórnvalda hafi ævinlega fylgt aukin skriffinnska og eftirlit. Fleiri fræðimenn sem fjalla um efnið taka í sama streng, peirra á meðal landi Graebers, stjórnmálafræðingurinn Patrick J. Deneen (2018), sem segir að hvað sem líði allri hugmyndafræði fylgi markaðsvæðingu í reynd alltaf aukin skriffinnska og miðstýring.

Hér verða reifaðar tvær sennilegar ástæður fyrir pví að samkeppni milli skóla kalli á aukinn atbeina ríkisvaldsins. Samkeppnin sem um ræðir er keppni um að fá meiri peninga með pví að laða til sín fleiri nemendur. Ástæðurnar sem ég reifa gilda pví ekki um allar gerðir af samkeppni milli skóla. Dær gefa til dæmis ekki tilefni til að halda eitt eða neitt um kapp sem birtist í pví 
að skólar reyni að senda góð lið í spurningakeppni eða á ípróttamót. En hverjar eru pessar tvær ástæður? Önnur er að skólar láta fólki í té fleiri gæði en kennslu. Deir færa fólki líka prófgráđur, skírteini og réttindi. Hin ástæðan er að samkeppni veldur stundum tortryggni eða vantrausti sem kallar á eftirlit sem elur svo á enn meiri tortryggni eins og skýrt var í síðasta kafla. Dessar ástæður tengjast og pótt ég geri grein fyrir peim í tvennu lagi held ég ekki að pær virki óháð hvor annarri.

\section{Fyrri ástæðan: Réttindi og gráour}

Eftir pví sem ég best veit getur pað vel gengið að hrein og klár kennsla sé til sölu á markaði par sem stundum er samkeppni milli seljenda. Ég býst við að petta gildi til dæmis með vandræðalitlum hætti um ökukennslu, en öðru máli gegnir hins vegar um bílpróf.

Hugsum okkur að ökukennarar hefðu ekki aðeins pað hlutverk að kenna nemendum, heldur byggi hver peirra líka til sitt eigið lokapróf sem skæri úr um hvort nemandi fengi ökuskírteini. Við pessi skilyrði myndu nemendur væntanlega ekki aðeins sækjast eftir að fá sem besta kennslu. Að minnsta kosti einhverjir peirra myndu líka sækjast eftir léttara bílprófi. Með pessu er ég ekki að segja að ökunemar vilji fá ökuskírteini án pess að kunna á bíl og mér dettur heldur ekki í hug að ökukennarar færu upp til hópa að útskrifa óhæfa ökumenn pótt peir sæju sjálfir um að meta kunnáttu nemenda sinna. Ég held hins vegar að ef nemendur fengju að velja milli tveggja ólíkra prófa til að sanna kunnáttu sína pá veldu flestir pað auðveldara, meðal annars til að koma í veg fyrir að smávægileg mistök eða prófstress tefði fyrir að peir fengju ökuskírteini. Í erindi sem Páll Skúlason flutti árið 2003, pegar hann var rektor Háskóla Íslands, orðaði hann hliðstæð rök í umfjöllun um samkeppni milli háskóla par sem hann sagði hreint út: „samkeppni veldur pví iðulega að minni kröfur eru gerðar og par með er dregið úr gæðum kennslunnar, pótt pjónusta við nemendur kunni að aukast" (Páll Skúlason, 2014, bls. 107).

Ef viðskiptavinir ökuskóla forðast pá ströngu sem gera pung próf pá slaknar trúlega smám saman á kröfunum án pess að neinn ætli beinlínis að minnka pær og pað endar með að of margir fara út í umferðina án pess að kunna nógu vel að keyra bíl. Lausnin á pessum vanda er samræmd bílpróf sem eru haldin af öðrum en peim sem selja ökukennslu. Dað er væntanlega vandi af svipuðu tagi sem veldur pví að notkun samræmdra prófa er mjög útbreidd í skólakerfum heimsins og minnkar ekki pótt skólum sé att í samkeppni. Pótt ef til vill sé hægt að kanna árangur ökunáms með samræmdu prófi án pess að of stór hluti pess sem máli skiptir fari forgörðum gildir bað ekki um nám í skólum. Ástæður pessa voru að hluta skýrðar í sjötta kafla par sem lýst var muninum á vonum og væntingum og ég segi ögn meira um pær í tíunda kafla.

Væntanlega er minni hætta á vanda af pessu tagi ef samkeppni um að ná í fleiri nemendur er lítil eða engin. Ef sextán ára unglingar fengju ekki að velja ökukennara heldur væru til dæmis skráðir í ökunám hjá peim kennara sem hefði einkaleyfi til að kenna í sveitarfélaginu eða hverfinu pá færi engin keðjuverkun í gang pótt kennararnir sæju um lokapróf. Sú lausn að banna fólki að velja sér ökukennara mæltist pó líklega illa fyrir og sömuleiðis er fjári hart að banna fólki beinlínis að velja milli skóla.

Skólar gefa út skírteini sem skipta máli og slík skírteini eru heldur vond markaðsvara. Detta er væntanlega ein veigamesta ástæða pess að markaðsvæðing menntakerfa dregur ekki úr miðstýringu, skriffinnsku og eftirliti. Баð er einfaldlega engin leið að gera góss á borð við prófgráður og starfsréttindi að hreinni og klárri söluvöru. Ástæður af pessu tagi hafa líka áhrif á grunnskóla sem ekki veita nein formleg réttindi. Peir útskrifa börn með vitnisburði sem hefur meðal annars áhrif á hvar pau komast að í framhaldsskóla og par með hvaða kjara pau njóta pegar pau verða fullorðin. 


\section{Seinni ástæðan:Vantraust}

Ef skólar eru í harðri samkeppni um að draga til sín nemendur með pví að bjóða gæði á borð við skírteini, góðan vitnisburð eða fleiri námseiningar með minni fyrirhöfn pá verður valt að treysta peim. Undir pessum kringumstæðum er hætt við vantrausti og pað verða til eftirlitsstofnanir sem hafa beinlínis hag af að pað aukist. Deir sem deila um hvort lausnin á vandanum er einkavæðing eða öflugri opinber stjórnsýsla láta gjarna eins og peir séu andstæðingar en hella samt hvorir tveggja olíu á sama eld.

Ef vandinn stafar af vantrausti pá leysist hann ekki með eftirliti sem endar með að skólastarf snýst meira um að gögn líti vel út en að nemendur menntist. Kannski leysist pessi vandi aldrei alveg en hann gæti minnkað ef reynt yrði að draga úr peim einkennum kerfisins sem helst ala á vantrausti og hlúa að peim sem ýta undir traust og metnað fólks á vettvangi til að vera traustsins vert. Eitt af pví sem hægt er að gera án pess að útiloka að nemendur og forráđamenn fái að velja skóla er að gæta pess að áhrif fjölgunar eða fækkunar nemenda á hag skóla séu hófleg pannig að pressan á pá að draga til sín sem flesta sé ekki mjög mikil, eða með öðrum orðum að hafa samkeppnina milli skóla heldur minni en meiri. Detta hefur að nokkru marki verið gert hér á landi par sem til dæmis hefur verið pak á pví hvað hver framhaldsskóli getur fengið greitt fyrir margar einingar. Рað græðir pví enginn neitt á að gramsa til sín mjög marga nemendur nema láta pá sjálfa borga, sem reyndar hefur tíðkast að nokkru marki pegar fjarkennsla er annars vegar. Annað sem kann að skipta máli er að styðja við fagmennsku af pví tagi sem lýst verður í tólfta kafla. •að priðja sem mér finnst líklegt að skipti máli er að fólk á vettvangi sem hefur hagsmuna að gæa hafi aðkomu að stjórn skóla. Ég hef hér í huga nemendur, foreldra, kennara og eftir atvikum fulltrúa starfsgreina pegar um nám til starfsréttinda í framhaldsskóla eða háskóla er að ræða. Aðhald sem petta skapar er talsvert öðru vísi en aðhald sem búið er til með eftirlitsstofnunum. Раð er væntanlega næmara á hvar skórinn kreppir.

Dótt ég viðurkenni að pessar tillögur byggist meira á tilfinningu og eigin reynslu en rökum sem standast kröfur um vandaða fræðimennsku ætla ég samt að reyna að orða ástæður til að treysta peim sem næstir eru vettvangi fyrir sem mestri ábyrgð á skólum.

Í bókinni um sýn yfirvalda á samfélagið sem nefnd var í sjötta kafla segir James C. Scott (1998, bls. 136): „Déttbýli par sem enginn nema lögreglan sér um að halda reglu á hlutunum er afar hættulegur staður." Hann er parna að ræða um borgarskipulag og hvað tryggi öryggi fólks og segir að í vel heppnuðu péttbýli prífist dáraskapur illa pví par sé sífellt í gangi alls konar óformleg nágrannavarsla par sem kaupmenn og veitingamenn sjá yfir götur og torg og nágrannar vita hver af öðrum. Í seinni bókum sínum segir Scott $(2012,2017)$ að svona félagsnet séu mun eldri en ríkisvald og markaðshagkerfi enda var pað, segir hann, fyrst fyrir um fjögur hundruð árum sem ríkisvald tók í raun og veru að móta lífsskilyrði alls porra jarðarbúa pó ríki hafi vissulega verið til mun lengur. Hann veltir pví fyrir sér hvort ríkis- og markaðsvæðing séu að eyðileggja getu fólks til að koma á og viðhalda skipulagi sem byggist á samvinnu jafningja fremur en valdstjórn, hvort pessir tveir risar, ríkið og markaðurinn, sem togast á um samfélög nútímans, komi beinlínis í veg fyrir að við lærum að vera frjáls og stjórna okkur sjálf.

Hugsunin hjá Scott er svipuð og hjá Dewey (1981-1990, 2. bindi, bls. 235-372) í bókinni um almannavettvanginn og vandamál hans sem nefnd var í síðasta kafla. Par lýsir Dewey stóru samfélagi sem klasa minni samfélaga fremur en sem safni einstaklinga. Dewey hafði pann skilning á siðuðu samfélagi að pað byggðist á pví að fólk stæði saman um einhver gildi, hagsmuni eða málstað og myndaði pess vegna alls konar misstóra hópa: Fjölskyldur, vinnustaði, starfsgreinar, stéttir og stéttarfélög, porp, nágrenni, söfnuði, klúbba og félög. Hóparnir tengjast bæði vegna pess að flestir einstaklingar tilheyra fleiri en einum og vegna pess að peir purfa hver á öðrum að halda. Í pessum hópum lærir fólk að lifa sem félagsverur, bera ábyrgð og hafa gætur á eigin samfélagi. Deneen (2018), sem var nefndur hér að framan, hugsar á svipuðum nótum par sem hann gagnrýnir markaðsvæðingu og skriffinnsku og segir að petta haldist í hendur og stuðli að niðurbroti smærri samfélaga sem eru nauðsynleg til að heilbrigt mannlíf fái prifist. Pótt pessir 
premenningar komist að svipuðum niðurstöðum nálgast peir efnið á afar ólíka vegu. Scott er mannfræðingur og hallur undir stjórnleysi. Deneen er íhaldssamur stjórnmálafræðingur og Dewey heimspekingur sem sótti innblástur bæði til Hegels og Darwins og ritskýrendur eru ekki sammála um hvar skuli staðsetja á litrófi stjórnmálanna (Atli Harðarson, 2016).

Hvernig heimfærum við petta sem Dewey, Scott og Deneen segja um smærri samfélög en ríkið og markaðinn upp á skóla? Hugsum okkur til dæmis að peir sem halda utan um fjármál einhvers skóla freistist til úrræða sem eru faglega ótæk en pað sé í raun hægt að ná endum saman með öðrum hætti. Undir pessum kringumstæðum getur skipt máli að annað fólk á vettvangi hafi vald og sameinist um að bera ábyrgð á heiðri skólans, velferð nemenda, námsgrein sinni eða hverjum peim öðrum gildum sem eru í húfi. Ef hvers kyns verðmæti sem skipta máli eiga sér málsvara sem geta látið til sín taka er síður hætt við að einsýni peirra sem mest hafa völdin verði til mikils skaða. Mín litla reynsla bendir til að mynda til pess að meðan ég starfaði sem framhaldsskólakennari hafi faggreinafélög kennara staðið vörð um metnaðarfulla kennslu í ýmsum greinum. Раð purfti ósköp lítið til að halda peim gangandi annað en ofurlitla styrki til að pau gæetu boðið upp á námskeið fyrir félagsmenn á sumrin og hóflega hvatningu til kennara að sækja sumarnámskeið. Par söfnuðust saman peir sem kenndu sömu grein og stöppuðu stálinu hver í annan.

Einkavæðingu og ríkisrekstri er stundum stillt upp sem andstæðum. Bæði rekstrarform rúma pó harða samkeppni milli stofnana, mikla samvinnu, hreina einokun og alls konar millistig. Dau rúma líka stjórn á vettvangi og miðstýringu að ofan. Einkaskóli getur verið með kennara og aðra starfsmenn sem ráđa ráđum sínum annað hvort vegna pess að peir sjálfir eiga skólann eða vegna pess að eigendur treysta peim. Hann getur líka verið útibú frá risafyrirtæki par sem allir á vettvangi eru valdalausir og fjarlæg stjórn reiðir sig á gögn sem hafa alla sömu annmarka og lýst var í sjötta og sjöunda kafla. Skóli í eigu ríkis getur leyft nemendum, starfsmönnum og grenndarsamfélagi að hafa meiri hluta allra fulltrúa í skólanefnd eins og gert var við íslenska framhaldsskóla fyrir daga nýskipunar í opinberum rekstri. ${ }^{8.1}$ Hann getur líka verið undir stjórn fjarlægra yfirvalda og hádur sífelldu eftirliti. Ríkisrekstur rúmar pví bæði möguleika á að fólk á vettvangi standi vörð um skólann sinn og að pað sé valdalaust og geti ekkert gert ef og pegar í óefni stefnir.

Einn af öflugustu og lærðustu talsmönnum einkavæðingar skólakerfisins, Englendingurinn James Tooley, ver hana á peim forsendum að hún færi vald nær vettvangi. Hliðstæða sögu er að segja um Bandaríkjamanninn Diane Ravitch sem er einhver skeleggasti og rökfastasti andstæðingur einkavæðingar sem ég veit af. Hún ver eignarhald hins opinbera á peim forsendum að pað gefi kost á að færa valdið til almennings.

\section{James Tooley um kosti einkaskóla}

Áherslan á að foreldrar og nemendur geti valið milli skóla hefur verið áberandi í málflutningi peirra sem mæla með einkavæðingu eða markaðsbúskap í menntakerfinu allt síðan hagfræðingurinn Milton Friedman (1955) skrifaði fræga grein um efnið sem birtist árið 1955. Mikilvægasti talsmaður markaðshyggju um skóla á seinni hluta síðustu aldar var pó líklega enski hagfræðingurinn E. G. West. Bók hans um menntamál og ríkisvald (Education and the State), sem út kom árið 1965, hafði veruleg áhrif á stefnu ríkisstjórnar Margaretar Thatcher á níunda áratug síðustu aldar. Enska hugveitan, eða áróðursstofnunin, The Institute of Economic Affairs, sem West starfaði fyrir, hafði líka áhrif á viðhorf fólks til hlutverka hins opinbera og málflutningur hennar átti mikinn pátt í endurvakningu frjálshyggju á síðustu áratugum tuttugustu aldar (Tooley, 2014).

Helsti merkisberi pessara hugmynda í samtímanum er James Tooley, prófessor við háskólann í Newcastle. Mikilvægustu rök hans gegn ríkisskólum eru að sjálfsprottin menntakerfi pjóni

8.1. Samkvæmt 7. gr. laga um framhaldsskóla nr. 57/1988 voru 7 fulltrúar í skólanefndum framhaldsskóla: Tveir fulltrúar starfsmanna, einn fulltrúi nemenda, prír fulltrúar hlutaðeigandi sveitarfélaga og einn skipaður af ráðherra án tilnefningar. Detta breyttist með lögum um framhaldsskóla nr. 80/1996 en samkvæmt 6. grein peirra skulu sitja fimm í skólanefnd, tveir eru skipaðir samkvæmt tilnefningu sveitarstjórna og prír af ráðherra án tilnefningar. 
almenningi betur en pau sem stofnað er til af stjórnvöldum (Tooley, 2013, 2014). Hann viðurkennir samt að heimildir skorti til að fullyrða að skólar hafi almennt versnað pegar skólaskylda var leidd í lög og skólar hins opinbera tóku að mestu við af einkaskólum. Hann segir pó ljóst að á Englandi hafi porri barna notið skólagöngu áđur en yfirvöld tóku að reka barnaskóla og að árið 1833 hafi Englendingar varið hærri hluta pjóðarframleiðslu sinnar til barnafræðslu en 1920. Meðan skólar voru að mestu einkafyrirtæki og reknir án atbeina ríkisins og án neinnar skólaskyldu hafi foreldrar pví kostað tiltölulega meiru til menntunar barna sinna en ríkið gerði áratugum eftir að skólaskylda var tekin upp með miklu regluverki og skriffinnsku. Tooley rekur söguna allt fram til okkar daga og gerir meðal annars grein fyrir pví að pegar reynt var að bakka út úr ríkisvæðingunni á valdatíma Thatcher og gera breytingar í anda Friedmans og West hafi útkoman í raun orðið aukið opinbert eftirlit, skriffinnska og pyngra regluverk. Tooley ræðir pessa pverstæðu frjálshyggjunnar, að hún sé í orði kveðnu á móti opinberum afskiptum en auki pau í reynd, og hann tekur undir með peim fræðimönnum sem hér hefur verið vitnað til sem segja að markaðsvæðing í anda nýskipunar í opinberum rekstri hafi ekki skilað tilætluðum árangri. Hvað álítur hann pá að virki til að færa vald yfir menntun barna til foreldra og fólks á vettvangi?

Tooley bendir á að pótt einkavæðing skóla á síðustu árum hafi ekki heppnast sem skyldi sé víða til gamalgróinn einkarekstur sem gengur vel og gefur fólki kost á að velja milli ólíkra skóla. Hann nefnir í pessu sambandi danska skólakerfið og pað hollenska og segir að í Hollandi hafi foreldrar, lögum samkvæmt, mátt velja skóla fyrir börn sín síðan 1917 og að par gangi ríflegur meiri hluti barna í einkaskóla. Sömuleiðis hafi dönsk lög tryggt rétt foreldra til að velja skóla síðan á nítjándu öld og par gangi allstór hluti grunnskólanema í einkaskóla. Í báðum pessum löndum greiðir hið opinbera kostnað við skólagönguna, hvort sem skólinn er eign hins opinbera eða einkaaðila.

Dekktastur er Tooley fyrir rannsóknir sínar á einkaskólum meðal fátæks fólks í priðja heiminum. Hann hefur ferðast víða til að rannsaka slíka skóla sem vaxa utan við lög og reglur, oft 1 ópökk stjórnvalda. Löndin sem hann segir frá eru meðal annars Indland, Nígería, Gana og Kenía. Niðurstöður hans komu flestum á óvart pegar pær voru fyrst kynntar. Pær voru í stuttu máli að víðast hvar par sem hann kannaði málið sendi stór hluti fátækra foreldra börn sín í einkaskóla, sniðgekk opinbera skólakerfið og greiddi allan kostnað við menntun barnanna úr eigin vasa. Tilraunir hans til að meta námsárangur í pessum einkaskólum benda til að peir bjóði að jafnaði upp á pokkalega kennslu og par sé almennt farið betur með börn en í ríkisskólum í fátækum landshlutum, enda séu einkaskólarnir háđir aðhaldi sem er nálægt vettvangi. Foreldrar taka börn sín einfaldlega úr peim ef peir reynast illa.

Tooley segist oftast fá sömu viðbrögð pegar hann kynnir niðurstöður sínar, að víst séu ríkisreknir skólar víða fyrir neðan allar hellur og par sé oft illa farið með börn, en ráðið við pví sé ekki að leita til einkafyrirtækja heldur að setja fleiri og ítarlegri reglugerðir um opinbert skólahald og veita meira fé til pess. Petta eru kunnugleg viðbrögð kerfiskarla og -kerlinga sem benda oft og iðulega á svipuð úrræði pegar eitthvað virkar alls ekki: Að gera meira af pví sama. Tooley svarar pessu á pá leið að víðast par sem fátæklingar kjósa einkaskóla dugi regluverk skammt, pví hver regla sem bætist við auki einfaldlega kostnað við mútugreiðslur til embættismanna sem taka fé fyrir að sjá gegnum fingur pegar ekki er farið eftir reglunum. Dví meiri peningar sem fara í mútur pví minna af peim gagnast börnunum.

Í ljósi pessara rannsókna gerir Tooley greinarmun á sjálfsprottinni einkavæðingu og einkavæðingu sem er stýrt af stjórnvöldum. Í tilvikum af seinni gerðinni setja yfirvöld yfirleitt reglur um skólahaldið, annast eftirlit og borga oftast megnið af kostnaðinum en í peim skólum sem hann hefur rannsakað á Indlandi og í nokkrum Afríkuríkjum koma yfirvöld hvergi nærri. Frásagnir hans af skólum víða um heim eru heillandi og pær sýna að fólk, sem virðist allar bjargir bannaðar, finnur leiðir fyrir börn sín pegar menntun peirra er í húfi og pað án atbeina stjórnvalda. Prátt fyrir margar fallegar sögur um einkaskóla sem hafa dafnað og nád að tengjast nágrenni sínu hefur Tooley pó hvorki svar við pví hvernig hægt sé að tryggja að sjálfsprottið skólakerfi nái til allra né hvernig hægt sé að koma í veg fyrir að pað endi í myndun stórfyrirtækja, fákeppni eða einokun 
par sem öll stjórn er fjarri vettvangi. Hann hefur heldur ekki lausn á vanda sem hlýtur að fylgja samkeppni um ,sölu“ á skírteinum sem veita forréttindi, en prófskírteini eru, eins og áđur segir, óheppileg söluvara á samkeppnismarkaði.

\section{Diane Ravitch um kosti skóla í eigu hins opinbera}

Diane Ravitch er prófessor við ríkisháskóla New York og hefur einnig verið háttsett í menntamálaráđuneyti bandarísku alríkisstjórnarinnar. Í bók sem kom út 2013 varar hún við einkavæðingu og markaðslausnum í skólakerfinu og andmælir stefnu sem mótuð var í forsetatíð Georges W. Bush og gekk undir nafninu „No child left behind“. Hún segir líka að framhaldið í forsetatíð Barachs Obama, pegar markaðslausnir með enn meiri skriffinnsku og eftirliti voru keyrðar áfram undir merkjum stefnu sem kallaðist „Race to the top“, hafi ekki verið hótinu skárra (Ravitch, 2013).

Hún rekur sögu markaðslausna í bandaríska menntakerfinu aftur til pess tíma pegar bókin Djóð í hættu (A Nation at Risk) kom út árið 1983, en hún var tekin saman að tilhlutan alríkisstjórnarinnar í forsetatíð Ronalds Reagan. Pá urðu pær breytingar, segir Ravitch, að markaðshyggja og áhersla á val foreldra um skóla var ekki lengur jaðarskoðun heldur hluti af stefnu sem varð almennt viðurkennd um mestallt litróf stjórnmálanna. Frá pví á nítjándu öld höfðu Bandaríkin haft skóla sem voru að mestu reknir af pví opinbera eða af stofnunum sem önnuðust skólahald án pess að gróðasjónarmið væru í fyrirrúmi. Nú eru, segir Ravitch, komnir fram einkaskólar sem eru reknir til pess eins að græða og samábyrgð almennings á menntakerfinu á í vök að verjast. Eitt form einkaskóla gagnrýnir hún sérstaklega. Рað eru peir sem bjóða eingöngu fjarnám. Мeð peim runnu saman prjár hreyfingar sem voru sókn í Bandaríkjunum pegar bókin var skrifuð: Einkarekstur í skólakerfinu; heimakennsla í stað skólagöngu; sala kennslu og námskeiða á netinu.

Ravitch rökstyður að opinbert skólakerfi í Bandaríkjunum hafi að flestu leyti staðið sig vel og kall eftir markaðsvæðingu vegna kreppu í skólamálum hafi ekki stuðst við neinar rannsóknir á veruleikanum. Máli sínu til stuðnings bendir hún annars vegar á að niðurstöður á rannsóknarprófum sem The National Assessment of Educational Progress hefur lagt fyrir úrtak nemenda með sama hætti um langt árabil fari batnandi og brottfall minnki og hins vegar að bandarískum efnahag og atvinnulífi vegni vel og framleiðni vinnuafls sé mikil í samanburði við pað sem gerist meðal annarra pjóða. Margir trúi pví að vísu að skólarnir séu ómögulegir en í Gallup-könnun árið 2012 gáfu samt 77\% aðspurðra skóla sinna eigin barna góða einkunn meðan aðeins 19\% gáfu skólakerfinu sem heild góða einkunn. Bandaríkin urðu pað sem pau urðu, segir hún, skapandi og öflugt samfélag, án markaðsvæðingar í skólakerfinu.

Hún segir að markaðsvæðing síðustu ára hafi orðið til pess að grafa undan hefðbundnu skólahaldi sem pjónaði samfélaginu vel og nefnir meðal annars að pessar breytingar hafi orðið til pess að skólar leggi ofuráherslu á greinar sem er prófað úr með samræmdum prófum og pví hafi dregið úr breiddinni í námsframboði. Fólk viti samt vel að börn purfa breiða almenna menntun og pað birtist meðal annars í pví að ríka fólkið sendir börn sín í einkaskóla með alvöru námskrá í anda frjálsra lista. Fleiri kostir hefðbundins opinbers skólakerfis segir hún að hafi farið forgörðum pótt rök og rannsóknir bendi til að rétt hefði verið að halda í pá. Hún nefnir í sérstaklega í pessu sambandi mikilvægi pess að treysta kennurum til að sjá um að búa til próf fyrir nemendur sína. Einnig telur hún mikilvægt að kennarar hafi aðkomu að stjórn skóla og að skólastjórar komi úr hópi reyndra kennara.

Ravitch fer hörðum orðum um ýmsa nýlundu sem fylgt hefur markaðsvæðingu skólakerfisins, eins og til dæmis pá stefnu sem fylgt hefur verið víða í Bandaríkjunum að reka kennara ef árangur nemenda peirra mælist lakur. Hún segir að engar rannsóknir sýni að pað skili neinum árangri. Sama segir hún um árangurstengingu launa kennara, öll gögn sýni að hún hafi engin áhrif í pá átt að bæta árangur nemenda. Ennfremur segir hún að flest tiltæk gögn og rannsóknir bendi til að par sem opinberir skólar og einkaskólar taka við svipuðum nemendahópum sé enginn munur 
á námsárangri. Sú hugmynd að einkarekstur og samkeppni bæti árangur styðjist pví ekki við annað en getgátur.

Boðskapur Ravitch er fremur íhaldssamur: Verjum gamla góða skólann gegn „byltingarsinnuðum“ hægri mönnum sem vilja kollvarpa hefðum sem hafa fyrir löngu sannað sig. Dessir „,byltingarmenn“ segir hún að vilji ryðja úr vegi skólanefndum og öðrum lýðræðislegum stofnunum, sem eru tregar í taumi, til að geta keyrt „umbætur“ sínar hratt í gegn. Skólanefndir par sem almenningur hefur eitthvað að segja hreyfa sig hægt. Dær rökræða. Dær hlusta á ólík sjónarmið. Dær standa ekki að djörfum umbyltingum. Dær vilja frekar að breytingar gerist smám saman. Đær eru í stuttu máli sagt lýðræðislegur vettvangur, mótvægi við sampjöppun valds. „Staðbundin stjórn á opinberum skólum er virðuleg amerísk hefð“ segir Ravitch og henni er umhugað um að verja pessa hefð (Ravitch, 2013, bls. 287).

Að mati Ravitch er alvarlegasti vandi skólabarna í Bandaríkjunum hvað mörg peirra alast upp við fátækt en ekki hvað skólarnir eru lélegir. Hún bendir á að í alpjóðlegum samanburði komi bandarískir skólar par sem innan við 10\% barna búa við fátækt afar vel út, álíka vel og skólar í Sjanghæ og betur en skólar í Finnlandi. Með pessu fellst hún ekki á að alpjóðleg samanburðarpróf á borð við PISA sé mikið að marka. Hún bendir raunar á að pau gefi ekki samanburðarhæfar upplýsingar ef nemendur í sumum löndum leggja sig fram til að pjóðin komi vel út en nemendum 1 öðrum löndum finnst ástæðulaust að reyna að standa sig á enn einu prófinu. Hún bendir líka á að pað sé ekkert samband milli árangurs nemenda á alpjóðlegum prófum og velgengni í efnahagslífi pjóða. Hún staðfestir raunar margt af pví sem Caplan segir, og rætt var í fjórða kafla, um að aukin skólaganga hafi lítil tengsl við hagvöxt. Um mælinga- og eftirlitsáráttuna sem fylgir markaðsvæðingu hefur hún sömu sögu að segja og Muller sem sagt var frá í sjöunda kafla. Víða í Bandaríkjunum hefur petta gengið svo langt að fimmtungur skólatíma fer í að pjálfa nemendur í að taka samræmd próf og ráđgjafarfyrirtæki sem hjálpa skólum að koma vel út úr mælingum draga til sín meira og meira fé.

Dótt Ravitch skrifi af mikilli pekkingu á bandarískum skólum og skilningi á hlutverki skóla og tengslum peirra við farsælt samfélag má efast um að tillögur hennar um að endurheimta skólann sem var fyrir fjörutíu árum séu að öllu leyti raunhæfar. Dað er óvíst að fjölmenningarsamfélög nútímans, par sem áhersla er lögð á mannréttindi einstaklinga fremur en samstöðu heildarinnar, nái sátt um neitt annað en að foreldrar og nemendur hafi val um skóla. Í Mannréttindayfirlýsingu Sameinuðu pjóðanna, sem er sá listi yfir mannréttindi sem flestir viðurkenna, er beinlínis kveðið á um í 26. grein að foreldrar eigi að ráða pví „öðrum fremur [...] hverrar menntunar börn peirra skuli njóta“. Ef petta ákvæði pýðir að foreldrar eigi beinlínis rétt á að velja milli skóla, skólagerða eða menntunarkosta fyrir börn sín er hæpið að pað verði að fullu virt án pess að af hljótist einhver samkeppni milli menntastofnana. Af ástæðum sem hér hafa verið raktar er afar sennilegt að sú samkeppni ýti að einhverju marki undir miðstýringu og eftirlit.

\section{Til umhugsunar}

Ef maður er svo pjófhræddur að hann eyðir aleigunni í pjófavarnarkerfi pá væri alveg jafn gott fyrir hann að vera rændur. Ýmislegt bendir til að eftirlit sem á að koma í veg fyrir að skólar standi sig mjög illa komi líka í veg fyrir að peir standi sig mjög vel. Detta gefur tilefni til að velta pví fyrir sér hvort ekki sé skárra að sleppa eftirlitinu og lifa við pað að einhver hluti alls skólastarfs verði hálfgert eða algert klúður.

a) Hver er best að eigi og reki skóla?

b) Durfa ríki og sveitarfélög að reka skóla til að börn fái góða skólagöngu?

c) Eiga börn og forráðamenn peirra að hafa val um í hvaða grunnskóla pau fara? Hvað með leikskóla, framhaldsskóla og háskóla?

d) Hvort er betra að tryggja öllum foreldrum tekjur til að kaupa pað sem börn peirra purfa eða að veita börnum tiltekin lífsgæði, eins og skólagöngu, ókeypis? 
Diane Ravitch er sérlega uppsigað við einkaskóla sem bjóða eingöngu fjarnám. Í sjötta kafla var bent á að par sem væntingar einar skipta máli teljast nemendur hafa lokið námi eða námsáfanga pegar peir standa skil á pví sem hægt er að gera kröfur um að allur nemendahópurinn geti sýnt og sannað að hann geti, kunni eða viti. Einnig var bent á að petta sé í mörgum tilvikum ósköp lítið, enda erfitt að miða væntingar við annað en lægsta samnefnara pess sem porri hópsins stendur skil á.

e) Er ástæða til að halda að petta gildi í meira mæli um fjarnám en staðnám? 


\section{Námsmarkmið}

Núgildandi aðalnámskrár fyrir leikskóla, grunnskóla og framhaldsskóla kveða á um að nám skuli skipulagt út frá námsmarkmiðum. Um pau segir í peim hluta textans sem er sameiginlegur fyrir öll skólastig: „Námsmarkmið snúa að peirri hæfni sem nemandinn öđlast í námsferlinu og býr yfir að námi loknu." Umrædd námsmarkmið eru kölluð einu nafni hæfniviðmið pótt peim sé skipað í prjá flokka sem kallast pekking, leikni og hæfni. Helst er að skilja að hæfnin sé aðalatriði en pekkingin og leiknin áfangar á leið til hæfni sem felur í sér fleira en pað eitt að vita og kunna. Hugtakið spannar nokkuð vítt svið og pað er áréttað par sem segir: „Hæfni er pannig meira en pekking og leikni, hún felur einnig í sér viðhorf og siðferðisstyrk, tilfinningar og sköpunarmátt, félagsfærni og frumkvæði“ (Mennta- og menningarmálaráðuneytið, 2011, bls. 23, 2012, bls. 23, 2013, bls. 25).

Pótt pessi orð sem vitnað var til séu í námskrám allra priggja skólastiganna gerir aðalnámskrá leikskóla ekki kröfur um að nám barnanna snúist um sókn að tilteknum hæfniviðmiðum. Par sem fjallað er um nám leikskólabarna sérstaklega er notað orðalag af allt öðru tagi en tíðkast par sem nám er skipulagt út frá hæfniviðmiðum, meira rætt um hvað skuli gera í skólunum og hvað nemendum skuli standa til boða en um hvaða hæfni peir skuli hafa að námi loknu (Mennta- og menningarmálaráðuneytið, 2011). Í aðalnámskrá grunnskóla virðist pó gert ráð fyrir að skipulag námsins snúist um að nemendur öðlist fyrir fram skilgreinda hæfni sem hægt er að lýsa með orðum og ganga úr skugga um að peir hafi tileinkað sér par sem viðmið um námsmat „eru lýsing á hversu vel nemandi hefur skilgreinda hæfni á valdi sínu“ (Mennta- og menningarmálaráðuneytið, 2013, bls. 55). Raunar kemur orðið „hæfniviðmið“ fyrir meira en tvö hundruð sinnum í aðalnámskrá grunnskóla eða að meðaltali um einu sinni á hverri blaðsíðu og stærstur hluti textans er ítarleg upptalning á hæfni sem nemendur eiga að hafa við lok fjórða, sjöunda og tíunda bekkjar. Hvað framhaldsskóla varðar krefst aðalnámskrá pess að hver einasti áfangi sé skipulagður út frá skráðum hæfniviðmiðum og lokamarkmið námsbrauta lýsi hæfni sem nemendur búa yfir við námslok (Mennta- og menningarmálaráðuneytið, 2012).

Dótt orðið „hæfniviðmið“ og flokkun markmiða í pekkingu, leikni og hæfni séu nýlunda í gildandi aðalnámskrám er áhersla á skipulag út frá markmiðum pað ekki. Í eldri aðalnámskrá grunnskóla segir til dæmis. „Skýr markmið eru grundvallarpáttur skólastarfs. Markmið eru leiðarvísir í öllu skólastarfi og forsenda áætlanagerðar um nám og kennslu. Pau stýra kennslunni og námsmatinu og eru grundvöllur mats á gæðum skólastarfs“ (Menntamálaráðuneytið, 1999f, bls. 22).

Raunar er pessi áhersla á markmið afsprengi bandarískrar hefðar sem rekja má rúma öld aftur í tímann til bókar eftir John Franklin Bobbitt sem heitir Námskráin (The Curriculum) og kom út árið 1918. Dessi hefð var síðan próuð áfram af Ralph W. Tyler, Benjamin S. Bloom, Hildu Taba og fleiri frumkvöðlum í námskrárfræðum við bandaríska háskóla um miðja síðustu öld og fyrir aldarlok varð hún nær ríkjandi í Bandaríkjunum, einkum meðal peirra sem fóru með yfirstjórn menntamála (Andri Ísaksson, 1983; Jackson, 1992; Reid, 2006; Elliott, 2009; Holt, 2009; Klein, 2009; Short, 2009; Au, 2011; Atli Harðarson, 2012b). Sama hefð hefur einnig haft veruleg áhrif 
í Evrópu par sem hún gengur nú í endurnýjun lífdaga í tilraunum til að samræma starfsnám og æðri menntun sem eru gjarna kenndar við Bologna og talað um Bologna-ferli (Karseth, 2006; Kennedy, Hyland og Ryan, 2006).

Andóf gegn pví að skipuleggja nám og kennslu út frá markmiðum sem eru ákvörðuð af nákvæmni fyrir fram á sér líka heillar aldar sögu pví Dewey mælti gegn slíku skipulagi um svipað leyti og Bobbitt vann að bók sinni (Atli Harðarson, 2018a). Tilbrigði við andmæli Deweys voru endurtekin 1 ýmsum myndum á seinni hluta síðustu aldar. Sumir afáhrifamestu andófsmönnunum gegn námskrám 1 anda Bobbitts, eins og Bretarnir R. S. Peters og Lawrence Stenhouse og Bandaríkjamennirnir Joseph Schwab og Maxine Greene, voru talsmenn frjálsra lista sem lögðu áherslu á að skipuleggja kennslu út frá námsefni fremur en námsmarkmiðum (Peters, 1966, 1973, 1977; Stenhouse, 1970, 1975; Schwab, 1978; Greene, 1973, 1978, 1988, 2001).

Rökræðan milli peirra sem leggja áherslu á að kennsla og skólastarf séu skipulögð út frá markmiðum og peirra sem mæla með skipulagi út frá námsgreinum er flókin fyrir margra hluta sakir. Eitt af pví sem er erfitt að henda reiður á er hvernig námsgreinarnar, hvort sem pær eru vísindi, fræði, tækni, ípróttir eða listir, tengjast markmiðum utan peirra sjálfra. Ég býst við að ég sé ekki einn um að verða hálfvegis ráðvilltur ef spurt er hvort fólk iðki ípróttir til að verða heilbrigt eða passi upp á heilsuna til að geta iðkað ípróttir, eða hvort við lærum tungumál til að geta lesið bókmenntir eða lesum bókmenntir til að bæta málakunnáttu okkar. Hjá flestum er petta kannski á báða vegu og óljóst og breytilegt hvað er tilgangur og hvað er tæki. Annað sem flækir umræðu um tengsl námsgreina og markmiða er að fólk uppgötvar ný markmið um leið og pað lærir. Dess vegna er hæpið að segja nemanda fyrir fram að hverju hann skuli keppa. Hann finnur sér ný keppikefli og sum peirra getur enginn séð fyrir vegna pess að stór hluti náms í skólum er í greinum sem breytast um leið og mannkynið aflar sér nýrrar pekkingar.

Nokkrir af peim heimspekingum sem fjölluðu um tengsl námsgreina við markmið skólastarfs undir lok síðustu aldar sögðu rökræðu um efnið á byrjunarstigi (White, 1982; Barnett, 1988; Winch, 1996). Næsti kafli er innlegg í pá rökræðu sem virðist enn á sama byrjunarstiginu. Í pví sem hér fer á eftir segi ég fyrst frá hefðinni sem Bobbitt mótaði og síðan frá andmælum gegn henni sem ég sæki til Stenhouse en hefði eins getað fiskað upp úr ritum eftir Dewey, Peters, Schwab eða Greene.

\section{Nemendamiðuð markmið}

Í bók sinni frá 1918 reyndi Bobbitt að móta vísindalega námskrárfræði og jafnframt fór hann hörðum orðum um pað sem áður var sagt um markmið og tilgang skóla:

Við höfum sett markið á óljósa menntun, illa skilgreinda tilsögn, pokukennt tal um alhliða proska einstaklinganna, ótiltekinn siðferðisproska eða félagslega skilvirkni sem ekki er útfærð í einstökum atriðum [...] en sá tími er senn liðinn að menn láti sér duga yfirgripsmikil og illa skilgreind markmið. Öld vísindanna krefst nákvæmni og útfærslu í einstökum atriðum. (Bobbitt, 1918/1972, bls. 41)

Með pessum ummælum sló Bobbitt tóninn fyrir tuttugustu öldina pegar vaxandi áhersla var lögð á vel skilgreind markmið sem undirstöðu allrar námskrárgerðar. Dessi markmið taldi hann unnt að finna með rannsóknum. Hann gerði ráð fyrir að vísindamenn gætu komist að pví hvaða hæfni fólk pyrfti að öðlast í skólum með pví að rannsaka hvað pað aðhefðist í raun og hvaða kunnáttu pyrfti til pess. Par sem hann ræðir til dæmis pörf fyrir kennslu í erlendum tungumálum byrjar hann á að spyrja í hverju fólki farnist illa vegna skorts á málakunnáttu.

Bobbitt viðurkenndi að vísu að erfitt væri að átta sig á hvaða pörfum tækist ekki að fullnægja vegna pekkingarskorts á sumum fræðasviðum eins og til dæmis sagnfræði. Hann hélt pví samt fram að menntun væri til að bæta úr skorti a kunnáttu og gerði rád fyrir að nám í skólum uppfyllti 
parfir sem fólk hefði fyrir fram og óháð skólagöngunni. Hann ræddi ekki pann möguleika að pörf fólks fyrir menntun væri lærð, að fólk fyndi til dæmis hjá sér pörf til að læra að skrifa nótur og útsetja lög vegna pess að pað hefði áður lært að syngja og leika á hljóðfæri.

Af eftirmönnum Bobbitts var landi hans, Tyler, áhrifamestur. Bók hans um grundvallarforsendur námskrár og kennslu (Basic Principles of Curriculum and Instruction), sem út kom 1949, varð höfuðrit um námskrármál á seinni hluta síðustu aldar (Elliott, 2007; Kliebard, 1987; Pinar, Reynolds, Slattery og Taubman, 1995). Dar tók Tyler undir með Bobbitt og sagði að markmiðssetning væri undirstaða allrar námskrárgerðar. Hann sampykkti pó ekki að markmiðin skyldu fundin með rannsóknum á pví hvernig fólk notaði pekkingu í raun og taldi að almenn yfirmarkmið skólastarfs hlytu að byggjast á pólitískum ákvörðunum fremur en vísindum. Að hans mati var pað hins vegar vísindalegt viðfangsefni að útfæra pau sem mælanleg markmið.

Á fyrstu síðu í bókinni setti Tyler kjarna námskrárfræða sinna fram sem fjórar spurningar par sem hann sagði:

Rökin sem hér eru útfærð byrja á að benda á fjórar meginspurningar sem verður að svara til að móta námskrá og kennsluáætlun. Đær eru:

1. Hvaða menntamarkmiðum á skólinn að leitast við að ná?

2. Hvaða menntandi reynsla getur orðið til pess að markmiðin náist?

3. Hvernig er hægt að skipuleggja pessa menntandi reynslu með skilvirkum hætti?

4. Hvernig getum við ákvarðað hvort markmiðin hafi náðst? (Tyler, 1949, bls. 1).

Af pví sem á eftir kemur er ljóst að Tyler áleit markmiðin purfa að lýsa athæfi sem nemendur gæu sýnt að námi loknu. Hann útilokaði að pað væru tæk markmið að tilgreina hvað kennari hygðist gera eða hvaða efni hann ætlaði að fara yfir. Námsskipan eins og lýst er í aðalnámskrá leikskóla par sem talað er um verklag og tækifæri sem nemendum bjódast var líka dæmd úr leik. Pað átti að lýsa pví hvað nemendur gætu að námi loknu.

Nokkrum árum eftir að bók Tylers kom út reyndi Bloom, ásamt samstarfsmönnum sínum, að gera ítarlega grein fyrir öllum gerðum námsmarkmiða. Flokkunarkerfi hans hafði mikil áhrif á skrif og kenningar um námsmarkmið og peirra gætir enn á pessari öld (sjá t.d. Marzano og Kendall, 2008). Líkt og Bobbitt og Tyler reyndi Bloom að fjalla um námsmarkmið með vísindalegum hætti og vera hlutlaus um öll siðferðileg og pólitísk álitamál. Detta var í dúr við vísindaheimspeki pósitífismans sem átti vaxandi fylgi að fagna um miðbik aldarinnar. Sú speki gerði strangan greinarmun á staðreyndum og gildum og kenndi að vísindin snerust aðeins um staðreyndir sem hægt væri að sannreyna en gætu ekki svarað spurningum um hvað væri eftirsóknarvert, rétt og gott og pess virði að lifa fyrir. Dessir premenningar voru líka allir undir áhrifum atferlisstefnu og töldu pví að námsmarkmið yrðu að lýsa atferli nemenda. Samkvæmt pessari stefnu í sálfræði, sem átti sitt blómaskeið á fyrri hluta síðustu aldar, var pað sem gerist í huganum og er ósýnilegt öđrum ekki tækt viðfangsefni. Vísindin skyldu halda sig við staðreyndir sem væru öllum aðgengilegar og rannsakendur gætu sannreynt, svo pótt fræðin hafi átt að vera hlutlaus um öll gildi tóku pau að minnsta kosti afstöðu gegn markmiðum sem ekki var hægt að útfæra sem atferli. Markmið á borð við pað að glæða skilning eða vekja áhuga og önnur hughrif töldust ekki tæk. Bloom gekkst við pessu par sem hann sagði:

Í einum skilningi er flokkunarkerfið pó ekki fullkomlega hlutlaust. Dessu veldur sú staðreynd sem nefnd hefur verið að um er að ræða flokkun á ætluðu atferli. Dað er ekki hægt að nota kerfið til að flokka námsáætlanir sem eru pannig að annað hvort sé ómögulegt að lýsa atferli nemenda eða að lýsingin felist aðeins í einu orði eða orðasambandi, svo sem eins og ,skilningur“ eða „eftirsóknarverður borgari“ (par sem engin greining fylgir). (Bloom, 1956, bls. 15) 
Dessi hefð í námskrármálum sem rekja má til Bobbitts tekur á sig ýmsar myndir. Nokkur meginatriði virðast pó lítt breytt í hundrað ár. Баð mikilvægasta er að markmiðin eru nemendamiðuð í peim skilningi að pau tilgreina hvernig nemandi verður að námi loknu en ekki til dæmis hvaða námsefni verður farið yfir eða hvaða verkefni verða unnin. Yfirleitt er gert ráð fyrir að ákvarðanir um námsefni, verkefni og kennsluhætti séu teknar eftir að markmiðin eru ákveðin. Annað kjarnaatriði er að yfirleitt er gert rád fyrir að hópur nemenda sem fær sömu kennslu nái sömu markmiðum. Баð priðja sem vert er að nefna er að einkum er hugað að markmiðum sem hægt er að skoða sem afleiðingar af skólastarfi, tilgreina af nákvæmni, ljúka og ganga úr skugga um að hafi verði lokið.

Um sumt annað hefur verið ágreiningur innan pessarar hefðar, til dæmis um pað hvernig markmið skuli ákvörðuð og að hve miklu leyti hægt sé að hanna skólastarf frá grunni út frá markmiðum. Helst er að skilja að Bobbitt hafi talið að námskrárgerðarmenn gæetu byrjað með hreint borð, en Hilda Taba (1962), sem ritaði um námskrárgerð með talsvert sterkari tengingu við raunverulegt skólastarf en helstu fyrirrennarar hennar, taldi slíkt ekki raunhæft. Hún lét að pví liggja að markmiðssetning væri fremur til að lagfæra námskrár skóla en til að smíða nýjar frá grunni.

\section{Efasemdir Stenhouse}

Lawrence Stenhouse hóf feril sinn sem framhaldsskólakennari í sögu og móðurmáli. Hann fann að pví að áhersla á markmið fremur en innihald gerði bókmenntirnar sem hann kynnti fyrir nemendum sínum að einberum verkfærum eins og pær hefðu ekkert eigið gildi og um leið skrumskældu markmiðin námsefnið í stað pess að láta pað njóta sín í ríkidæmi sínu og fjölkynngi.

Aðrar efasemdir Stenhouse um að rétt væri að skipuleggja skólastarf út frá nemendamiðuðum markmiðum voru einkum af tvennu tagi. Annars vegar benti hann á að nemendum væri fært frelsi með pví að leggja áherslu á námsgreinar og byggja námskrána á pví að tilgreina innihald fremur en markmið. Hins vegar rökstuddi hann að námsmarkmið næðu ekki utan um allt pað sem mestu skipti í skólastarfi (Stenhouse, 1970).

Fyrri rökin, pessi sem snúast um frelsi nemenda, virðast hugsuð á pá leið að ef tilgreint er hvað verði gert pá geti nemendur nýtt sér pað hver á sinn hátt. Ef boðið er upp á áfanga í framhaldsskóla par sem verður farið yfir Brennu-Njáls sögu nýtir einn nemandi hann kannski til að fá efni í orðaleiki og brandara og annar sem tilefni til að velta fyrir sér samskiptum karla og kvenna.

Gott námsefni býður nemendum upp á marga og ólíka möguleika og frelsi til að velja milli peirra. Detta gildir ekki aðeins um listaverk á borð við Njálu. Ef við hugsum um námsgrein eins og skólasund pá er hún, ef vel tekst til, einum nemanda tækifæri til að auka styrk og prek, öðrum fyrst og fremst skemmtun. Deim priðja finnst hann ef til vill ekki fá neitt út úr pví að synda fram og til baka en nýtur pess svo seinna á ævinni að kunna íprótt sem hann getur notað til að halda skrokknum í lagi. Ef handverksgreinar í grunnskóla eru kenndar með myndarbrag pá eru pær einum ef til vill undirbúningur fyrir iðnnám, öðrum uppspretta tómstunda seinna á ævinni og peim priðja tækifæri til að eignast nothæfa flík fyrir lítinn pening. Svipað má segja um fleiri greinar, að góð kennsla sem snýst um gott námsefni býður nemendum margs konar tækifæri. Fyrir suma hefur stærðfræðin til dæmis einkum hagnýtt gildi, öðrum er hún íprótt, uppspretta hugmynda til að nota við listsköpun eða heillandi heimur fullur af fegurð og töfrum.

Látum petta duga um frelsi nemenda og hugum að síðasttöldu andmælunum sem ég eignaði Stenhouse. Hugsunin á bak við pá mótbáru að markmið nái ekki utan um allt pað sem mestu máli skiptir birtist með skýrum hætti í dæmi sem hann orðaði á pessa leið: 
Menntun [...] heppnast að svo miklu leyti sem hún gerir atferli nemenda ófyrirsjáanlegt.

Hugsum okkur að pað sé verið að fara yfir söguritgerðir. Sá sem fer yfir pær parf að lesa pær ansi margar.

Sem hann les stendur hann oft frammi fyrir peirri dapurlegu staðreynd að ritgerðirnar eru hver annarri líkar [...] En pað leynist samt ein og ein í staflanum sem er frumleg, kemur á óvart, sýnir merki um sjálfstæða hugsun. Dessar ófyrirsjáanlegu, pað eru pær sem eru til marks um árangur. (Stenhouse, 1975, bls. 82)

Ef pað er rétt hjá Stenhouse að kennsla af einhverju tagi heppnist best pegar nemandi kemur kennara sínum á óvart pá getur kennarinn varla sett mjög nákvæm atferlismarkmið fyrir nemandann. Раð fer einfaldlega ekki saman að segja einhverjum nákvæmlega hvað pau skuli gera og vænta pess um leið að pau geri eitthvað óvænt.

Til viðbótar við pessar athugasemdir segir Stenhouse að krafan um ítarleg markmið sé oft sett fram í annarlegum tilgangi, ekki til að bæta skólagöngu nemenda heldur til að hanka kennara, píska pá áfram eða kalla til ábyrgðar.

\section{Markmið og skóli án aðgreiningar}

Hluti af andmælum Stenhouse gegn pví að skipuleggja skólastarf út frá nemendamiðuðum markmiðum byggist á pví að nemendur eru ólíkir. Ef kennari hefur mjög einsleitan hóp getur hann kannski horft fram hjá pessu og gert rád fyrir að allir tileinki sér sams konar hæfni sem metin verður með einum kvarða á prófi sem er eins fyrir alla, en petta á sjaldan við. Í venjulegum bekk eru nemendur með ólíkan bakgrunn og ólíka getu.

Hugtökin „skóli án aðgreiningar“ og ,skóli margbreytileikans“ hafa verið notuð til að árétta skyldu okkar til að haga skólastarfi pannig að pað gagnist öllum nemendum. Dessi skylda hefur verið viðurkennd af yfirvöldum, að minnsta kosti í orði kveðnu, síðan Salamanca-yfirlýsingin var pýdd á íslensku og kynnt af Menntamálaráðuneytinu árið 1995 (Mennta- og menningarmálaráðuneytið, 2015). Yfirlýsing pessi varð til ári fyrr, 1994, á heimsráðstefnu um menntun barna með sérparfir sem var haldin í borginni Salamanca á Spáni. Með henni varð pað viðurkennt á alpjóðavettvangi að almennir skólar væru fyrir öll börn (Dóra S. Bjarnason, Hermína Gunnpórsdóttir og Ólafur Páll Jónsson, 2016; Gretar L. Marinósson og Dóra S. Bjarnason, 2016).

Ef til vill má hugsa sér leiðir til að sætta markmiðsdrifna námskrá og skóla án aðgreiningar með reddingum á borð við að skilgreina annars vegar markmið sem henta nokkurn veginn fyrir porra hópsins og svo önnur markmið fyrir pau fáu sem skera sig verulega úr, til dæmis vegna fötlunar eða tungumáls. Pessi leið gerir nær óhjákvæmilega ráð fyrir pví að hópnum sé skipt í pau venjulegu og hin - pau sem stefna að markmiðunum sem eru talin æskilegust og pau sem purfa að sætta sig við eitthvað minna. Sú leið Stenhouse að bjóða nemendum upp á ferðalag gegnum námsefni sem orkar með ólíkum hætti á ólíka einstaklinga kallar miklu síður á svona skiptingu hópsins og samræmist betur viðurkenningu á pví að nemendahópar séu sundurleitir.

\section{Til umhugsunar}

a) Er hægt að skipuleggja kennslu í grunnskóla út frá hæfni sem allir nemendur eiga að hafa við lok fjórða, sjöunda og tíunda bekkjar en haga kennslunni samt pannig að allir njóti góðs af henni?

b) Er árangursrík menntun sókn að markmiðum sem aðrir hafa skilgreint eða pvælast pau fyrir fólki sem leitar nýrra leiða? 
Hugsum okkur að framhaldsskóli bjóði upp á valáfanga í ensku par sem lesið verður leikrit eftir Shakespeare. Hugsum okkur að Sigríður velji áfangann vegna pess að hún hefur áhuga á leiklist og hana langar til að verða leikari og að Björn velji áfangann vegna pess að hann hefur áhuga á málfræði og hann langar til að læra hvernig enskan hefur breyst undanfarin fjögur hundruð ár.

c) Getur kennarinn skilgreint hæfniviðmið sem henta öllum nemendum jafn vel, líka Birni og Sigríði?

Kennarahópur í leikskóla fer fram á pað við sveitarstjórn að hluta af lóð skólans verði breytt í garð par sem börnin fá að rækta kartöflur og fleiri matjurtir. Yfirmaður á skrifstofu sveitarfélagsins svarar erindinu og segir að ekki sé hægt að afgreiða pað nema kennararnir geri grein fyrir pví hvaða námsmarkmiðum breytingin pjónar. Kennararnir ræða málið og eiga erfitt með að koma sér saman um markmið. Aldís segir að petta sé til pess að búa börnin undir nám í náttúrufræði seinna og hjálpa peim að skilja mikilvæg sannindi um lífríkið og um hvernig matvæli verða til. Pavlova segir að pað stuðli að sjálfbærum samfélagsháttum að allir venjist á að nota matvæli af heimaslóð. Ævar telur hins vegar rétt að leggja áherslu á að garðvinnan geri skólagöngu barnanna ánægjulegri, pau finni tilgang í pví að búa til matvæli og verði stolt pegar pau taka uppskeruna með heim og gefa foreldrum sínum.

d) Er hægt að nefna fleiri góð og gild markmið en pau sem Aldís, Pavlova og Ævar stinga uppá?

e) Er einhver leið að velja milli peirra eða yrði slíkt val einungis handahófskennt?

f) Hvort er trúlegra að skipulag skólagarðsins ráđist af markmiðum eða að markmiðin séu skálduð eftir á til að réttlæeta framkvæmdirnar?

Námsmarkmið sem fylgja forskriftum hefðarinnar eru yfirleitt sett fram sem markmið sem nemendur eiga að ná sem einstaklingar. Sumt skólastarf virðist falla illa að pessari forskrift. Hugsum okkur til dæmis að kennari fari með bekk sinn í leikhúsferð. Hugsum okkur líka að tveir nemendur í bekknum séu í hljómsveit og peir ákveði að æfa og flytja lag úr leikritinu. Einn nemandi verður hugfanginn af sýningunni og ákveður að læra leiklist og verða leikari. Svo eru nokkrir sem höfðu bara gaman af pessu og nokkrir sem heilluðust af pví hvað aðalleikarinn var með flotta vöðva og góður í fimleikum. Рað sem nemendur fá út úr sýningunni er pví misjafnt frá manni til manns, en pað sem samfélagið fær út úr pví að farið sé með börn í leikhús er að leiklist heldur áfram að vera til. Eitt og eitt barn fær nægan áhuga til að taka síðar pátt í að próa listgreinina.

g) Getur kennarinn skilgreint hæfniviðmið fyrir leikhúsferðina? Hver gætu pau verið? Ná pau að lýsa tilgangi ferðarinnar? 


\section{0. Ólík vensl markmiða og leiða}

Í síðasta kafla var fjallað um andmæli gegn markmiðsdrifnu námi. Dau ber ekki að skilja svo að andmælendurnir vilji að skólastarf sé tilgangslaust, enda hæpið að nokkur maður sjái skynsemi í pví að vinna án pess að ætlast eitthvað fyrir með vinnunni. Andmælin beinast gegn of einfaldri mynd af pví hvernig viðleitni fólks tengist pví sem hún beinist að. Dessi einfalda mynd gerir, eins og tæpt var á, rád fyrir pví að:

- Rétt sé að tilgreina námsmarkmið fyrir fram af nákvæmni.

- Hægt sé að ná peim og ganga úr skugga um að peim hafi verið nád.

- Dau náist sem afleiðingar af pví sem gert er í skólanum og skólastarfið hafi gildi vegna pessara afleiðinga.

Detta prennt gildir vissulega um sumt nám og sumt starf. Eitt af hæfniviðmiðunum í aðalnámskrá grunnskóla er til dæmis að við lok sjöunda bekkjar geti nemandi „synt viðstöðulaust baksund, skriðsund og kafsund $8 \mathrm{~m}$ auk pess að stinga sér af bakka“ (Mennta- og menningarmálaráðuneytið, 2013, bls. 184). Petta markmið er tilgreint fyrir fram, pað er hægt að ná pví, sýna fram á að pað hafi náðst og væntanlega er árangurinn afleiðing af kennslu og bjálfun í sundi.

Dótt petta prennt sem er talið hér að ofan gildi um sum námsmarkmið sem unnið er eftir gildir petta hvorki almennt og yfirleitt um námsmarkmið né önnur markmið sem stýra viðleitni okkar. Lítum nánar á pessu prjú atriði. ${ }^{1.10 .}$

\section{Fyrsta atriði: Er rétt að tilgreina markmið fyrir fram af nákvæmni?}

Ein leið til að átta sig á kostum ónákvæmrar markmiðssetningar er að rifja upp söguna um naglasúpuna. Hún segir frá manni sem kemur á bæ par sem húsfreyja tímir ekki að gefa honum að borða. Hann segir að hún purfi litlu til að kosta, hann sé með pennan fína nagla og pað sé hægt að sjóða af honum súpu. Húsfreyja lætur til leiðast að setja pott á hlóðir og sjóða naglann upp úr blávatni. Gesturinn segir pá að súpan verði enn betri ef hún finnur eitthvað til að setja út í hana, pað megi vera hvað sem er, til dæmis mjöl eða grjón. Pegar petta hefur soðið smá stund nefnir hann að til að búa til veislumat úr pessu purfi ekki annað en henda dálitlu af grænmeti í pottinn. Á pessu gengur svolitla stund og fleira og fleira sem til er ætilegt í kotinu er látið saman við. Á endanum mallar dýrindis súpa í pottinum. Húsfreyjan er höfð heldur einföld í sögunni og látin trúa pví allan tímann að naglinn, sem gesturinn var með í vasanum, sé meginuppistaða matarins.

Í pessari sögu hafði gesturinn augljóslega markmið, sem var að matreiða eitthvað gott. Hann gat pó ekki lýst markmiðinu af nákvæmni fyrir fram, pví hann varð að nýta pað sem gestgjafinn fékkst til að setja í pottinn og gat ekki vitað hvað pað yrði. Ef hann hefði byrjað með tiltekna uppskrift og nákvæma lýsingu á einhverjum tilbúnum rétti pá hefði hann líklega ekki fengið neitt að borða.

Í hversdagslegu lífi förum við stundum eftir uppskriftum og eldum stundum eins og naglasúpukokkar. Oftast förum við líklega bil beggja, byrjum með uppskrift og víkjum aðeins 
frá henni vegna pess að samkvæmt matreiðslubókinni á kannski að nota rófur en við eigum aðeins gulrætur.

Degar við eldum naglasúpu spyrjum við hvernig við getum notað pað sem við höfum og sættum okkur við að lokamarkmiðum okkar sé aðeins lýst í grófum dráttum - pau séu ,yfirgripsmikil og illa skilgreind“" svo notað sé orðalag Bobbitts (1918/1972, bls. 41) sem vitnað var til í síðasta kafla. Slík markmið hafa pann kost að hægt er að nýta pað sem hendi er næst sem oft kostar mun minna en að kaupa allt sem parf til að fá fyrir fram ákveðna afurð. Aðferðir af pessu tagi bjóða líka upp á að sjá tækifæri í pví óvænta. Ef húsfreyjan í sögunni hefði komið með kjöt eða fiskbita pegar gesturinn stakk upp á að hún fyndi grænmeti pá hefði hann væntanlega tekið pví fagnandi.

Degar við eldum eftir uppskrift pá spyrjum við hvernig við getum fengið pað sem okkur vantar fremur en hvernig við getum nýtt pað sem við höfum. Kosturinn við slíka aðferð er að hægt er að staðla framleiðsluna eins og gert er pegar iðnvarningur er fjöldaframleiddur.

Í hugbúnaðarfræðum og verkfræði eru aðferðir sem minna á naglasúpuna stundum kallaðar neðansæknar par sem byrjað er á að henda reiður á pví hvað er til og unnið út frá pví að einhverju sem sóst er eftir. Aðferðir af síðarnefndu gerðinni kallast ofansæknar par sem byrjað er með nákvæma lýsingu á afurðinni og leitt af henni hvaða aðföng parf.

Hugmyndir um að markmiðum skólastarfs skuli lýst fyrir fram af nákvæmni gera ráð fyrir að skólinn sé líkari iðnaði par sem staðlaðar einingar eru fjöldaframleiddar heldur en eldamennsku par sem reynt er að nýta pað sem til er í búrinu, en petta eru aðeins líkingar. Raunverulegur skóli er hvorki verksmiðja né eldhús. Dar parf sífellt að vinna bæði með ofansæknum aðferðum par sem sum lokamarkmið eru nokkuð nákvæmlega tilgreind og með neðansæknum aðferðum par sem nemendur og kennarar sjá tækifæri í pví óvænta.

\section{Annað atriði: Er hægt að ná markmiðunum og ganga úr skugga um að peim hafi verið nád?}

Sum markmið sem stýra hversdagslegri viðleitni eru af pví tagi að peim verður ekki lokið. Sem dæmi um slík markmið má nefna heilbrigt líf, að reynast vinum sínum vel, farsælt hjónaband eða viðleitni til að proskast og temja sér dygðir eins og hugrekki, æðruleysi, hófsemi, visku, sanngirni og góðvild. Pessi markmið eru ekki eins og vörður á leið okkar sem við göngum að og höfum pá lokið peim áfanga. Dau eru líkari leiðarstjörnu sem við notum til að átta okkur pótt við séum ekki beinlínis á leiðinni pangað.

Markmið eins og heilbrigt líf gefur tilefni til að setja sér undirmarkmið sem hægt er að ná. Slík undirmarkmið geta til dæmis verið að skokka klukkustund á hverjum laugardegi næsta árið. Degar árið er liðið hefur pað markmið kannski náðst og klárast. Heilbrigði er hins vegar ekki markmið sem er beinlínis hægt að klára. Raunar er sama hvað okkur tekst vel að vinna að pví, við verðum á endanum lasin og deyjum ef ekkert annað verður fyrr til að binda enda á líf okkar. Ef heilbrigði er markmið pá stýrir pað viðleitni sem er ekkert vit í að ætla sér að ljúka. Dað sama má segja um vináttu, gott hjónaband og viðleitni til siðferðilegs proska. Fólk sem ætlar að klára petta og segja einn daginn ,nú er hjónaband okkar orðið nógu gott“ eða „,nú erum við orðin hófsöm“ skilur líklega ekki hvers konar viðleitni er um að ræða.

Markmiðin sem hægt er að klára, pessi sem líkja má við vörður, pjóna oft markmiðunum af hinu taginu, peim sem líkja má við leiðarstjörnuna. Að skokka klukkutíma á hverjum laugardegi getur verið hluti af viðleitni til að vera hraustur og heilbrigður. Í mörgum tilvikum eru markmiðin sem hægt er að klára ekki sérlega mikilvæg. Flest fólk væri trúlega til í að endurskoða petta með skokkið af litlu tilefni og synda eða hjóla í staðinn. Hins vegar parf talsvert að ganga á til að fólk gefi markmið eins og heilbrigt líf upp á bátinn. Мeð öðrum orðum eru markmiðin sem skipta mestu máli og við ættum síst að víkja frá í flestum tilvikum líkari leiðarstjörnu en vörðu. 
Dessi greinarmunur á markmiðum sem stýra viðleitni sem hægt er að klára og markmiðum sem ekki nást eða klárast gildir jafnt um nám og annað sem fólk gerir. Hann er raunar náskyldur greinarmuninum sem Illich gerði á vonum og væntingum og sagt var frá í sjötta kafla. Markmið sem hægt er að klára og ganga úr skugga um að hafi klárast eru pau sem hægt er að gera kröfur um að fólk standi skil á. Pau sem stýra ævilangri viðleitni verða ekki prófuð til hlítar við lok misseris eða skólaárs. Pótt gildandi aðalnámskrár leggi áherslu á hæfniviðmið sem hægt er að ljúka og prófa hvort nemendur hafi náð virðist aðalnámskrá grunnskóla viðurkenna að til séu markmið af öðru tagi par sem segir að ,sum markmið eru pess eðlis að ekki kemur fram fyrr en síðar á lífsleiðinni hvort peim var nád eða ekki““ (Mennta- og menningarmálaráðuneytið, 2013, bls. 56).

Fyrir nokkrum árum síðan skoðaði ég markmið í nokkrum námsgreinum í aðalnámskrá framhaldsskóla frá árinu 1999 (Atli Harðarson, 2012a). Dessar greinar voru íslenska, náttúrufræði, samfélagsgreinar og stærðfræði (Menntamálaráđuneytið, 1999b, 1999c, 1999d, 1999e). Í sumum áföngum sem par var lýst var farið nokkuð strangt eftir forskrift hefðarinnar sem fjallað var um i síðasta kafla og námsmarkmiðin sett fram sem markmið sem hægt var að klára. Eitt skýrasta dæmið var áfangi sem hét Eðlisfræði 303. Par voru tilgreind markmið eins og að nemandi yrði fær um að: Finna orku og hraða hlaðinna einda sem fara yfir spennumun; útskýra hvernig íspenna spanast í spólu pegar segulflæði um hana breytist; teikna upp rafsvið og segulsvið í rafsegulbylgju (Menntamálaráðuneytið, 1999c). Valið á pessum markmiðum eðlisfræðiáfangans virðist hafa stjórnast af viðleitni til að færa nemendum skilning á raf- og segulkröftum og tengslum peirra við ýmis fyrirbæri í náttúrunni og heimi tækninnar. Detta yfirmarkmið gerir markmiðin sem hægt er að ná að hluta af viðleitni sem er ekki beinlínis hægt að ljúka. Pað er ekki aðeins leiðarstjarna. Dað er líka hæfilega ónákvæmt og yfirgripsmikið til að menn sjái tækifæri í pví óvænta, til dæmis ef einn daginn gengur á með prumum og eldingum, ef nemendur sjá norðurljós á himni eða ef einhver fær rafstuð frá næsta manni sem hefur rennt sér á sokkaleistunum eftir gólfinu. Detta yfirmarkmið var pó ekki orðað í námskránni.

Viðleitni til að skilja raf- og segulkrafta lýkur ekki fremur en annarri viðleitni til að öðlast skilning á veruleikanum. Í hvert sinn sem einhver árangur næst vakna nýjar spurningar. Eru lögmál pessara krafta afleiðingar af almennari lögmálum sem gilda um alla krafta í náttúrunni? Verka pau eins á öllum tímum og á öllum stöðum í geimnum? Sumar spurningarnar tengjast verkfræði og hagnýtum greinum og varða til dæmis möguleika á að smíða afkastameiri tölvur. Aðrar eru á mörkum heimspeki og vísinda par sem spurt er hvort pessir kraftar geti verkað pótt enginn nemi pá eða hvort til geti verið tómarúm án peirra.

Ég hefði eins getað tekið dæmi úr öðrum greinum en eðlisfræði og af öðrum skólastigum en framhaldsskóla. Í unglingadeildum grunnskóla lesa nemendur gjarna Íslendingasögur eða endursagnir á peim. Баð er hægt að kenna til dæmis Laxdæla sögu og skipuleggja námið að verulegu leyti út frá markmiðum sem hægt er að ná og klára. Hætt er pó við að kennslan verði heldur leiðinleg ef ekki er reynt að skilja hvað fólkinu sem frá segir gengur til og hvaða boðskap sagan flytur. Spurningar um slík efni renna nær óhjákvæmilega saman við viðleitni til að skilja ástarbríhyrninga, valdatafl, mannlegar hvatir og félagslegan veruleika. Um slíka viðleitni má segja, rétt eins og um viðleitni til að skilja ríki náttúrunnar, að ef vel gengur eignast menn ekki aðeins svör heldur líka dýpri spurningar.

Ef við einblínum á markmið sem hægt er að ná eða ljúka og staðfesta með námsmati að nemendur hafi náð pá er hætt við að pað sem mestu skiptir glutrist niður og nemendur eignist aðeins svör til að standa skil á en ekki spurningar sem vekja löngun til að læra meira. Бað er líka hætt við að ofuráhersla á markmið sem hægt er að klára verði til pess að markmiðin sem mestu skipta og eru leiðarljós skólans séu hvorki rökrædd né gagnrýnd. Ef viðleitni hlýtur að stjórnast af yfirmarkmiðum sem ekki er hægt að ná pá má ætla að pað sé að minnsta kosti stundum heppilegt að orða pau og ræða fremur en að ganga einungis að peim sem gefnum. 


\section{Driðja atriði: Eru markmiðin afleiðingar af skólastarfinu?}

Fólk sem hefur einhvern tíma dansað til að skemmta sér veit væntanlega að tilgangur pess sem við gerum er ekki endilega nein lokaafurð. Fólk með sæmilega fullu viti stígur ekki dans til pess að uppskera skemmtun að honum loknum. Skemmtunin er innifalin í athæfinu og pannig er með margt af pví besta sem við gerum, pað hefur tilgang í sjálfu sér. Petta gildir jafnt um lærdóm eins og um leiki eða vinnu. Að rökræða saman um sögu, reyna sig i íprótt, leysa stærðfræðipraut, petta er allt pess virði að gera sjálfs pess vegna.

Í fimmta kafla Lýdrææðis og menntunar ræðir Dewey um hvað drífur fólk áfram í námi og segir að fjarlæg markmið geti ekki verið driffjöður daglegrar iðju. Dewey fjallaði um sama efni í lengra máli í grein um áhuga og iðjusemi í námi (,,Interest and Effort in Education“) sem birtist premur árum fyrr, eða 1913 (Dewey, 1976-1983, 7. bindi, bls. 151-159). Par segir hann að hvert verkefni purfi að hafa nærtæk markmið sem nemendur gera að sínum. Ef ég skil hann rétt geta slík markmið verið hversdagsleg eins og að klára að lesa bókarkafla, teikna mynd eða prjóna húfu. Sé starfið áhugavert og skemmtilegt drífur pað nemendur áfram og vinnugleðin gerir skólastarfið árangursríkt. Hins vegar er, segir Dewey, erfiðara að ýta undir vinnugleði með markmiðum sem eru fjarlægar afleiðingar pess sem verið er að gera og sé einblínt á slík markmið verður prautalendingin hjá kennurum ýmist að reyna að pvinga nemendur til að læra með ströngum aga eða að spilla námsefninu með pví að hlaða utan á pað einhverju skemmtiefni - ,sykurhúða pað svo hægt sé að narra nemendur til í að innbyrða efni sem peir kæra sig ekkert um“ (Dewey, 1976-1983, 9. bindi, bls. 60). Degar kennsla heppnast hvað best parf, samkvæmt pessu, hvorki refsingar né verðlaun. Баð sem parf er verk sem nemendur eru til í að vinna af dugnaði vegna pess аð peir taka pað alvarlega og finnst pað mikilvægt.

Í bókinni Eðli og athafi mannsins (Human Nature and Conduct) frá 1922 ræðir Dewey um mikilvægi pess að iðja okkar hafi gildi sjálfrar sín vegna og segir eitthvað á pá leið að ef við fórnum hverju núi fyrir árangur í framtíð pá séu mestar líkur á að við fórnum allri ævinni fyrir ávinning sem aldrei fæst (Dewey, 1976-1983, 14. bindi, bls. 182-189). Farsælt líf er væntanlega líf par sem flestir dagar færa fólki eitthvað sem er gott í sjálfu sér en ekki aðeins vegna pess að pað hafi góðar afleiðingar og petta hlýtur að gilda um pann hluta ævinnar sem fólk er í skóla. Ef vel tekst til er skólastarfið ekki aðeins gott vegna afleiðinga sinna heldur líka vegna pess að fólk lifir góðu lífi í skólanum.

Ef skóli á að kenna fólki að meta pað besta sem mannkynið á í sjóði vísinda, fræða, lista, tækni og íprótta verður pað varla gert öðru vísi en að nemendur njóti pessara gæða í skólanum. Fari peir á mis við petta og upplifi skólagönguna aðeins sem sókn að markmiðum sem nást í framtíðinni pá er raunar afar ósennilegt að margir nái miklum árangri.

\section{Tæknihyggja um nám og kennslu}

Sú einfalda mynd af námsmarkmiðum sem hér hefur verið gagnrýnd er ein af mörgum birtingarmyndum pankagangs sem Páll Skúlason (1987) lýsti sem tæknihyggju. Námskrárhefðin sem lýst var í síðasta kafla gerir rád fyrir pessari einföldu mynd, en eins og ég hef reynt að skýra er hún of einföld. Markmiðin sem stýra, og hljóta að stýra, viðleitni til að kenna og læra í skólum eru flókin blanda af eftirtöldu:

- Markmiðum sem eru tilgreind fyrir fram af nákvæmni og markmiðum sem aðeins er lýst 1́ grófum dráttum.

- Vörðum og leiðarstjörnum - með öðrum orðum markmiðum sem hægt er að klára og markmiðum sem stjórna viðleitni fólks pótt pau náist ekki.

- Markmiðum sem eru (oft fjarlægar) afleiðingar af skólastarfi og markmiðum sem eru innbyggð í starfið og gefa pví gildi hvað sem öllum afleiðingum líður. 
Ef petta er rétt og ef námsmarkmið eru jafn margbreytileg í eðli sínu og ég held pá er eitthvað bogið við ríkjandi stefnu í námskrárgerð. Ef mér skjátlast ekki hrapalega pá er ekkert vit að reyna að skipuleggja allt skólastarf út frá hæfni sem er tilgreind fyrir fram af nákvæmni og sérhver nemandi á að hafa náo pegar hann lýkur námi.

\section{Til umhugsunar}

Í aðalnámskrá grunnskóla eru tilgreind hæfniviðmið í íslensku við lok tíunda bekkjar. Dar segir meðal annars að nemendur eigi að geta:

- Nýtt sér fjölmiðla, svo sem útvarp, sjónvarp, kvikmyndir og rafrænt efni, og tekið afstöðu til pess sem par er birt.

- Átt góð samskipti par sem gætt er að máli, hlustun, tillitssemi, virðingu og kurteisi.

- Lesið almenna texta af öryggi og með góðum skilningi, lagt mat á pá og túlkað.

- Tjáð hugmyndir sínar og skoðanir og fært rök fyrir peim í rituðu máli, samið texta frá eigin brjósti og verið óhræddir við að beita ríkulegu tungutaki í skapandi ritun.

- Áttað sig á og beitt sköpunarmætti tungumálsins og nýtt pað við ritun, tal, nýyrðasmíð,í orðaleikjum og skáldskap. (Mennta- og menningarmálaráđuneytið, 2013, bls. 101-105)

a) Eru pessi fimm hæfniviðmið tilgreind af nákvæmni eða eru pau „yfirgripsmikil og illa skilgreind"?

b) Er hægt að ná peim eða lýsa pau fremur viðleitni sem ekki getur lokið?

c) Er heppilegt að hugsa um pau sem afleiðingar af skólastarfi eða eru pau ef til vill inn byggð í vel heppnað skólastarf?

d) Eru petta vel heppnuð hæfniviðmið?

e) Væri betra að orða einhver peirra öðru vísi?

f) Gefa pessi „hæfniviðmið“ ástæður til að efast um að grunnskólar eigi í raun og veru að skipuleggja starf sitt út frá eiginlegum hæfniviðmiðum, pað er að segja lýsingu á hæfni sem allir nemendur hafa að námi loknu?

g) Er trúlegt að margt fullorðið fólk hafi alla pá hæfni sem sagt er að unglingar eigi að ná fyrir lok tíunda bekkjar? 


\section{Umbætur eða skólapróun}

Í síðasta kafla var lýst tæknihyggju um námskrár. Hliðstæður pankagangur setur líka svip á tilraunir stjórnvalda til að setja skólum almenn markmið. Рað virðist oft gert ráð fyrir að hægt sé að lýsa pví fyrir fram hvaða áhrif skólinn skuli hafa á nemendur sína og samfélagið og ákveða svo út frá markmiðunum hvað gert skuli í skólunum. Dessi hugsun er einföld og virðist ef til vill skynsamleg við fyrstu sýn. Hljóta yfirvöld sem reka skóla ekki að setja peim markmið og ætlast til að skólastjórnendur og kennarar hagi starfinu pannig að markmiðin náist? Hljóta umbætur á skólum ekki að hefjast á að skilgreina svo góð markmið sem vera má og leiða svo af peim undirmarkmið og pannig koll af kolli par til komið er að pví sem kennarar og nemendur eiga að gera? Rök fyrir umbótum sem eru skipulagðar með pessum hætti út frá almennum yfirmarkmiðum má finna í skrifum eftir John White $(1997,2006)$.

Hollenski námskrárfræðingurinn Jan van den Akker (2003a) hefur fjallað um ofansæknar aðferðir af pessu tagi og skipt stigveldinu frá stefnumótun yfirvalda til pess sem nemendur í raun læra í sex hæðir. Á efstu hæðinni eru gildi og hugsjónir, pá fyrirmæli í plöggum frá stjórnsýslunni eins og lögum, reglugerðum og námskrám. Fyrir neðan pessar tvær hæðir sem eru ofan við hið eiginlega skólastarf koma miðhæðirnar par sem skólastjórnendur og kennarar eru í aðalhlutverkum. Á peirri efri er skilningur peirra á námskránni og fyrirmælum yfirvalda og par fyrir neðan hvað peir reyna að gera í raun og veru. Á neðstu hæðunum tveimur er annars vegar pað sem nemendur skynja og upplifa og að síðustu pað sem peir á endanum læra.

Ef við heimfærum pessa stigskiptingu Akkers upp á íslenskt skólakerfi getum við sagt að menntapólitísk markmið og aðalnámskrár með sína grunnpætti og hæfniviðmið tilheyri efstu tveimur hæðunum. Sama má segja um almenn yfirmarkmið sem tilgreind hafa verið í lögum, reglugerðum og námskrám. Slík markmiðssetning hefur lengi tíðkast. Í reglugerð fyrir Hinn almenna menntaskóla í Reykjavík frá árinu 1904 sagði til dæmis að markmið skólans væri að „efla sálar- og líkamsproska nemendanna“ (Kristinn Ármannsson o. fl., 1975, bls. 70) og í lögum frá seinni hluta síðustu aldar eru ákvæði um að skólar búi nemendur sína „undir líf og starf í lýðræðissamfélagi““ (Lög um framhaldsskóla nr. 57/1988).

Fjöldi rannsókna bendir til að pess háttar markmiðssetning á efstu hæðum stigveldisins hafi yfirleitt lítil áhrif og að afar torvelt sé fyrir stjórnvöld að breyta skólum með stefnumótun eða markmiðssetningu (Sarason, 1971; Popkewitz, Tabachnick og Wehlage, 1982; Hamilton, 1989, 1990; Cuban, 1992; Tyack og Cuban, 1995; Katz og Denti, 1996; Tye, 2000; Akker, 2003a, 2003b). Allmargir fræðimenn sem fjalla um umbætur á skólakerfum orða erfiðleika við að koma á miðstýrðum umbótum með svipuðum hætti og segja eitthvað á pá leið að skólar lagi stefnu yfirvalda að starfsháttum sínum fremur en starfshættina að stefnunni (Popkewitz o.fl., 1982; Tyack og Cuban, 1995; Tye, 2000). Sagnfræðingarnir David Tyack og Larry Cuban eru pekktir fyrir rannsóknir sínar á umbótatilraunum fræðsluyfirvalda í Bandaríkjunum á tuttugustu öld. Deir fjalla um úrræði í anda tæknihyggju, par sem markmið eru ákveðin af æðstu yfirvöldum og ætlast til að lægra sett stjórnvöld og kennarar hrindi peim í framkvæmd, og segja að reynslan sýni að pað sé afar hæpið að slík úrræði beri nokkurn tíma pann árangur sem að er stefnt (Tyack 
og Cuban, 1995). David Hamilton (1989), sem pekktur er fyrir rannsóknir á skólasögu nokkurra Evrópulanda, tekur í sama streng og lýsir tæknihyggjunni sem óraunhæfum draumórum. Allmargir fræðimenn sem segja í öðru orðinu að yfirvöld purfi að móta menntastefnu viðurkenna í hinu orðinu að raunverulegt skólastarf mótast mikið til af öðru en stefnumótun stjórnvalda (sjá t.d. Taba, 1962; White, 2004).

Sá vandi sem hér um ræðir er líklega ekki séreinkenni á skólakerfum. Væntanlega er jafn erfitt að miðstýra öðrum flóknum kerfum par sem fólk á vettvangi parf að leysa margvísleg vandamál og laga starfið аð аðstæðum og pörfum á hverjum stað. Að ætla peim að keyra í gegn markmið sem eru fyrir fram ákveðin af yfirvöldum og fylgt eftir með einhvers konar gagnadrifinni stjórnsýslu af pví tagi sem rætt var um í sjöunda kafla verður ef til vill alltaf óraunhæf einföldun á flóknum veruleika.

\section{Breytingar á námskrá}

Að stjórnvöldum gangi oft erfiðlega að skipuleggja breytingar á skólum pýðir ekki að peir séu kyrrstæðir, aðeins að erfitt sé að stjórna breytingunum. Sú skólasaga sem ég sjálfur man og hef tekið pátt í gerðist að mestu í framhaldsskóla par sem ég starfaði, fyrst sem kennari og svo sem skólastjórnandi, frá 1986 til 2014. Árið sem ég hóf störf sem kennari kom út í fyrsta sinn námskrá handa framhaldsskólum (Menntamálaráðuneytið, 1986). Sú námskrá var að mestu leyti aðeins skráning á námsbrautum og áföngum sem höfðu orðið til við nokkra nýstofnaða fjölbrautaskóla næsta áratug á undan, en fjölbrautakerfið varð til árið 1975 pegar Fjölbrautaskólinn í Breiðholti var stofnaður og Flensborgarskóla í Hafnarfirði var breytt í fjölbrautaskóla. Á næstu árum voru stofnaðir svipaðir skólar víða um land, til dæmis á Suðurnesjum 1976, á Akranesi 1977, á Sauðárkróki 1979 og á Selfossi 1981.

Sumar námsbrautirnar í fyrstu fjölbrautaskólunum voru byggðar á iðnbrautum við eldri iðnskóla og sumar á bóknámsbrautum við eldri menntaskóla en breytingarnar á fjölda og samsetningu námsleiða sem unglingum stóðu til boða voru samt verulegar. Dessar breytingar gerðust að mestu með samstarfi kennara og skólastjórnenda.

Einn peirra manna sem fylgdust með námskrármálum fjölbrautaskóla frá byrjun er Jón F. Hjartarson. Hann var áfangastjóri við Fjölbrautaskóla Suðurnesja pegar hann var stofnaður árið 1976 og varð premur árum síðar fyrsti skólameistari Fjölbrautaskóla Norðurlands vestra á Sauðárkróki. Í grein sem birtist 1990 lítur Jón yfir farinn veg og lýsir hraðfara próun á námskrám fjölbrautaskólanna sem grasrótarstarfi án mikillar miðstýringar. Hann talar um tímabil lögleysu fram til 1990 og vísar til pess að pá fyrst var tekið að vinna eftir nýsettum lögum um framhaldsskóla en fyrir setningu peirra árið 1988 hafði ekki verið nein heildarlöggjöf um skólastigið (Jón F. Hjartarson, 1990).

Á pessum uppvaxtar- og mótunartíma fjölbrautaskólanna voru námskrármál að mestu á forræði skóla. Flestir peirra samræmdu pó námskrár sínar að pví marki sem purfti til bess að nemendur gætu skipt um skóla án pess að pað tefði fyrir brautskráningu og nokkrir skólar stóðu saman að útgáfu námsvísa. Sá fyrsti var gefinn út sameiginlega af Flensborgarskóla, Fjölbrautaskóla Suðurnesja og Fjölbrautaskólanum á Akranesi árið 1978. Síðar bættust fleiri skólar í hópinn. Námskrá ráđuneytisins sem út kom 1986 byggðist að mestu leyti á pessum námsvísum sem urðu til fremur hratt í samstarfi sem var að mestu að frumkvæði kennara og skólastjórnenda.

Kennarar sem störfuðu við menntaskóla fyrir daga fjölbrautakerfisins og ég hef rætt við segjast hafa haft mjög frjálsar hendur við val námsefnis. Deir sem kenndu sömu greinar höfðu samráð og kennslubækur höfðu áhrif en pað var engin miðstýrð námskrárgerð (Atli Harðarson, 2010b). Detta breyttist með útgáfu aðalnámskrár framhaldsskóla 1999 (Menntamálaráđuneytið, 1999a). Par var reynt að miðstýra náminu með lýsingum á einstökum áföngum og ítarlegum fyrirmælum um hvaða námsbrautir mættu vera til og hvaða áfangar skyldu vera á hverri peirra. Degar pessi 
námskrá hafði verið í gildi í áratug kannaði ég hve vel breytingar sem hún boðaði höfuu náð fram að ganga. Viðtöl sem ég tók við átján kennara veturinn 2009 til 2010 leiddu í ljós að skólarnir fundu sér ýmsar leiðir til að víkja sér undan fyrirmælum aðalnámskrárinnar. Eldri skólarnir breyttu starfsháttum sínum síður til samræmis við fyrirmæli yfirvalda heldur en peir yngri og munaði yfirleitt pví meiru pví eldri sem skólinn var. Fleiri rannsakendur hafa komist að svipuðum niðurstöđum. Hafdís Ingvarsdóttir tók til dæmis viðtöl við tungumálakennara við tíu íslenska framhaldsskóla. Dar kom fram að kennararnir könnuðust við breytingar á kennsluháttum sem boðaðar voru í námskrám en enginn peirra hafði „tileinkað sér pær nema að hluta“ (Hafdís Ingvarsdóttir, 2007, bls. 377).

Einn viðmælenda minna ýjaði að skýringu á pví að fyrirmæli ráðherra í námskrá væru ekki ævinlega framkvæmd af kennurum par sem hann sagði: „Kennsla er bara pess eðlis að menn verða að fá að fljúga eins og peir eru fiðraðir“" (Atli Harðarson, 2010b). Hafdís benti líka á mögulega skýringu par sem hún reifaði kenningar pess efnis að „,pví berskjaldaðri sem kennarar telja sig gagnvart nemendum, yfirvöldum, foreldrum, einhliða mælikvörðum á starf peirra o.s.frv. peim mun íhaldssamari verði peir og ófúsari að taka að sér breytingastarf“" (Hafdís Ingvarsdóttir, 2007, bls. 378).

Dessi saga námskrár við íslenska framhaldsskóla virðist koma heim og saman við pað sem Akker, Tyack, Cuban, Hamilton og fleiri hafa sagt um tilraunir stjórnvalda til umbóta á menntakerfum, að miðstýrðar umbætur hafa iðulega önnur áhrif en að er stefnt. Detta gildir til dæmis um tilraunir stjórnvalda hér á landi til að vinna gegn brottfalli úr framhaldsskólum sem rætt var um í sjöunda kafla. Рað dæmi snerist pó um stefnumótun sem var fremur óumdeild og var fylgt eftir með pví að nota öflug stjórntæki eins og reiknilíkan og árangurstengd framlög til skóla.

Sumar breytingar sem verða án pess neinn skipuleggi pær mæta pörfum sem fólk finnur fyrir á vettvangi og sumar nýjungar sem teknar eru upp með pólitískum ákvörðunum ganga væntanlega greitt vegna pess að fólk er upp til hópa sammála peim. Slíkar breytingar eru skiljanlegar í ljósi parfa og áhuga sem menn vita af, en svo verða líka breytingar á skólum án pess að ljóst sé að neinn kæri sig um pær. Mér pykir trúlegt að rýrnandi hlutur list- og handverksgreina sé dæmi um breytingu sem hefur orðið án pess hún skýrist beinlínis af pörf sem við vitum af eða sé í samræmi við neina meðvitaða ákvörðun. Skömmu eftir að fyrsti íslenski menntaskólinn var stofnaður 1904, og tók við af Lærða skólanum, fylltu list- og handverksgreinar nálægt 13\% af kennslutímanum en áður en öldin var liðin var hætt að kenna pær sem hluta af skyldunámi til stúdentsprófs (Kristinn Ármannsson o.fl., 1975). Svipað virðist hafa gerst í grunnskólum. Í grein eftir Brynjar Ólafsson (2009) kemur fram að allan seinni helming síðustu aldar fór hlutfall kennslutíma í listog verkgreinum af heildarkennslutíma lækkandi hjá 11 ára nemendum, mjakaðist úr rúmum 17\% árið 1948 í rúm 14\% árið 1999.

\section{PISA og umbótaplágan}

Hér hafa verið reifuð almenn sannindi um hve torvelt er að breyta skólum. Engu að síður hafa stjórnvöld í mörgum löndum reynt í vaxandi mæli að knýja fram umbætur með regluverki og stefnumótun ofan frá pað sem af er pessari öld. Angi af pessari viðleitni er aukin skriffinnska og eftirlit eins og rætt var um í sjöunda og áttunda kafla. Íslenskt skólafólk pekkir hana sem innleiðingu á stefnu um hitt og petta, allt frá upplýsingakerfum og innra mati til heilsueflingar og skóla án aðgreiningar.

Eitt af pví sem hefur drifið pessa umbótaviðleitni áfram er alpjóðlegur samanburður á árangri skóla og skólakerfa. Hér hefur munað mest um PISA-próf sem lítillega var sagt frá í sjötta kafla. Víða hafa ríkisstjórnir brugðist við niðurstöðum peirra með úrræðum í anda nýskipunar í opinberum rekstri og reynt að nýta hagræna hvata og eftirlit til að knýja fram betri árangur. Dessar umbótatilraunir hafa verið rannsakaðar af finnskum manni sem heitir Pasi Sahlberg. Hann hóf feril sinn sem kennari í stærðfræði og raungreinum við finnskan menntaskóla en gegnir nú 
prófessorsstöðum í menntavísindum við háskóla bæði i Finnlandi og Bandaríkjunum. Í bókarkafla eftir Sahlberg (2016) segir hann að viðbrögð stjórnvalda víða um heim séu svipuð og hann talar í pví sambandi um albjóðlega hreyfingu í skólamálum. Hann segir að helstu einkenni hennar séu að stjórnvöld noti samræmdar mælingar á árangri til að veita skólum aðhald; staðli námskröfur og kennsluhætti; komi á samkeppni milli skóla; auki áherslu á lestur, stærðfræði og náttúrufræði á kostnað annarra greina og noti aðferðir sem hafa mótast hjá fyrirtækjum á markaði til að innleiða breytingar. Hver er síðan árangurinn? Greining Sahlbergs sýnir að í löndum par sem mest kveður að „umbótum“ af pessu tagi fara einkunnir á PISA-prófum lækkandi.

Sahlberg kallar pessa albjóðlegu hreyfingu The Global Education Reform Movement og notar skammstöfunina GERM pegar hann fjallar um hana. Hún er orðaleikur bví „germ“ getur merkt sýkill og hann líkir umræddri viðleitni við plágu sem herjar á menntakerfi heimsins.

Degar PISA-könnun var fyrst lögð fyrir árið 2000 héldu flestir sem höfðu skoðun á málinu að finnskt skólakerfi væri frumstætt og gamaldags. Fjárútlát til pess voru með minna móti og kennslustundir sem nemendur fengu á ári færri en víða annars staðar. Finnar höfðu ekki breytt skólum sínum í samræmi við nýjustu tísku í opinberum rekstri par sem átti að líkja eftir samkeppni á markaði. Pað bættist svo við annan útkjálkabrag hjá peim að kennarar og skólar höfðu sjálfræði um námsefni og námsmat. Lítið var um stöðlun og aðhald af hálfu stjórnvalda. Dað kom pví verulega á óvart að finnskir unglingar voru í efsta sæti og stóðu sig betur en jafnaldrar í öðrum löndum. Um petta má lesa í bók eftir Sahlberg (2017) sem heitir Finnska leiðin og Félag grunnskólakennara gaf út í íslenskri pýðingu.

Ef pað sem Sahlberg segir er rétt pá er ekki aðeins um pað að ræða að miðstýrðar breytingar sem eiga að bæta skóla nái misvel fram að ganga. Sumar algengar og útbreiddar tegundir af miðstýrðum „umbótum“ virðast beinlínis skaðlegar.

\section{Til umhugsunar}

Á fyrri hluta tíunda áratugar síðustu aldar boðuðu íslensk stjórnvöld miklar umbætur á framhaldsskólum. Баð var ræett um að breyta skipan skólanefnda, valdsviði skólastjóra sem og reglum um ráðningu kennara. Раð átti að lengja skólaárið, fækka námsárum til stúdentsprófs, fækka stúdentsbrautum, taka upp samræmd stúdentspróf og auka tengsl við atvinnulíf (Menntamálaráđuneytið, 1993, 1994). Ný lög litu dagsins ljós 1996 og námskrá í samræmi við pau kom út 1999. Aðeins hluti boðaðra breytinga náði fram að ganga og sumar, eins og samræmd stúdentspróf, byrjuðu seinna en áætlað var og gengu fljótt til baka (Atli Harðarson, 2010b).

Sagan endurtók sig rúmum tíu árum síðar pegar mikil umræða var um ný framhaldsskólalög. Pau voru sett 2008 og námskrá í samræmi við pau 2011. Samkvæmt lögunum áttu skólar að skilgreina námsbrautir og par með var horfið frá miðstýringunni sem tekin var upp með námskránni frá 1999 pegar Menntamálaráðuneytið skilgreindi námsbrautir fyrir allt framhaldsskólakerfið. Reglur um hvernig mætti skilgreina námsbrautir og námskrárgrunnur til að skrá pær birtust svo nokkrum árum síðar og fyrstu brautirnar voru sampykktar haustið 2014 (Menntamálastofnun, e.d.). Pá var enn talsverð óvissa um hvernig skólar mættu haga skipan iðn- og starfsmenntabrauta (Stefanía Helga Stefánsdóttir, 2019).

Í báðum pessum tilvikum fór nær heill áratugur í bið eftir skýrum fyrirmælum. Sem hliðstæðu við pennan biðtíma skulum við hugsa okkur götu í péttbýli par sem eru fallegir garðar við flest húsin. Einn daginn tilkynnir sveitarstjórnin umbætur á götunni. Hún á ef til vill að breikka og gangstéttirnar líka og svo á að setja nýja ljósastaura og skjólgott biðskýli par sem strætisvagninn stoppar. Menn búast við að teikningar liggi frammi fyrir árslok en pegar drög að peim eru sýnd koma upp efasemdir um að hægt sé að vinna eftir peim svo pað parf að endurskoða teikningarnar. Vegna pessa líða nokkur ár án pess að nokkur maður viti hvað nýja gatan tekur stóran hluta af görðunum. Fyrir vikið hirða fáir um limgerði og beð á lóðamörkum og enginn lagfærir 
girðingar pví pað er eins víst að pær verði rifnar. Degar framkvæmdum við götuna er loks lokið eru garðarnir alls ekki eins fallegir og peir voru.

a) Er líkingin við breytingarnar á götunni hjálpleg til að skilja áhrif umbóta á skólastarf?

b) Er pessi líking að einhverju leyti villandi eða óheppileg?

c) Herjar umbótaplága á íslenska skóla? 


\section{Fagmennska kennara}

Íslensku orðin „fagmaður“ og „fagstétt“ eru notuð til að pýða ensku orðin „professional“ og „profession“ en merkingin er samt ekki alveg sú sama. Enska orðið „professional“ nær bæði yfir fagmennsku og atvinnumennsku og hefur að pví leyti víðari merkingu en „fagmaður“ en á hinn bóginn er merking ensku orðanna stundum einskorðuð við háskólamenntaðar stéttir en ekki látin ná yfir iðnaðarmenn. Íslensku orðin ná hins vegar ævinlega jafnt yfir iðnaðarmenn og fólk í störfum sem krefjast háskólamenntunar. Drátt fyrir pennan merkingarmun virðist inntak orðanna skarast að mestu leyti. Dau eru gildishlaðin og fólki er hrósað pegar sagt er að pað vinni fagmannlega en álasað ef sagt er að vinnubrögð séu ekki fagmannleg. Dessi orð gefa til kynna að einhverjum sé treystandi til að vinna sjálfstætt vegna pess að viðkomandi búi yfir sérpekkingu, hafi tileinkað sér hollustu við gildi starfsins og láti eigin stundarhag víkja ef hann stangast á við skyldur sem starfinu fylgja (Hoyle, 1982; Carr, 2014; Hermansen, 2017; Atli Harðarson, 2019a).

Degar stétt nýtur viðurkenningar sem fagstétt er henni að einhverju marki treyst til að stjórna vinnu sinni og oftast nær líka til að annast menntun og inntöku nýliða. Sem dæmi má nefna að til að ganga inn í stétt iðnaðarmanna parf að njóta kennslu hjá iðnmeistara í greininni og standast sveinspróf sem sveinsprófsnefndir semja og bera ábyrgð á (Reglugerð um námssamninga og starfspjálfun nr. 280/1997). Í peim nefndum eru iðnaðarmenn úr viðkomandi iðngrein (Reglugerð um sveinspróf nr. 698/2009). Svipað gildir um lögmenn. Til að fá réttindi til að flytja mál fyrir dómstólum purfa peir að standast próf sem priggja manna nefnd annast, par af er einn tilnefndur af Lögmannafélagi Íslands og annar af Dómarafélagi Íslands (Lög um lögmenn nr. 77/1998).

Víða um heim hafa kennarar lengi sóst eftir pví að vera viðurkenndir sem fagstétt en gengið misvel. Hér á landi varð umræða um fagmennsku kennara áberandi eftir að Kennaraskólinn breyttist í Kennaraháskóla 1971 og kennarastéttin var tekin að beita sér fyrir lögverndun á starfsréttindum sínum (Helgi Skúli Kjartansson, 2008). Lög um pað efni gengu í gildi 1986 (Lög um lögverndun á starfsheiti og starfsréttindum grunnskólakennara, framhaldsskólakennara og skólastjóra nr. 48/1986) og um svipað leyti kynntu Broddi Jóhannesson (1978), Jónas Pálsson (1983), Wolfgang Edelstein (1988), Sigurjón Mýrdal (1992) og fleiri hugmyndir um fagmennsku kennara sem byggðist á sérfræðilegri pekkingu og skuldbindingu við gildi starfsins. Umræðan hér var endurómur af pví sem sagt var í öđrum löndum par sem kennaramenntun færðist víða á háskólastig um svipað leyti. Drátt fyrir mikla umræðu um efnið í hálfa öld (Maxwell, 2015) vantar pó töluvert á að kennarastéttin njóti í raun viðurkenningar sem fagstétt. Sérfræðipekking hennar er umdeild og faglegt sjálfstæði víða mjög takmarkað sem og aðkoma stéttarinnar að menntun og inntöku nýliða.

\section{Sérfræðipekking kennara}

Allur porri fólks sinnir kennslu að minnsta kosti endrum og eins. Við kennum hvert öðru spil og leiki, stálpuð börn kenna yngri systkinum að sitja reiðhjól eða reima skó, kunningi segir mér hvernig á að nota nýlegt forrit. Svona má lengi telja. Kunnátta sem parf til pess að kenna og segja 
öðrum til er hluti af hversdagslegri lífsleikni, en hér hefur kennsla ekki sérstöðu. Flest purfum við einhvern tíma að hjúkra sjúkum, elda mat, gera við flík eða dytta að húsum og mörg okkar rækta kartöflur og önnur matvæli. Hluti af pekkingu hjúkrunarfólks, matreiðslumanna, klæðskera, húsasmiða og búfræðinga skarast pví við hversdagslega kunnáttu sem fjöldi fólks hefur á valdi sínu. Í mörgum greinum, eins og matargerð, fatagerð og landbúnaði er borin virðing fyrir albýðlegum hefðum og sérfræðingar sækja fyrirmyndir í pær. Detta kastar sjaldan neinni rýrð á sérpekkingu peirra fagmenntuðu. Við gerum almennt ráð fyrir að peir búi yfir hæfni sem máli skiptir og er töluvert umfram pað sem flest fólk veit og kann, en hvað með kennara?

Kennari parf að sjálfsögðu að kunna pað sem hann kennir. Enskukennari parf til dæmis að kunna ensku og pað er hæpið að ósyndur maður kenni sund svo vel sé, en er einhver pekking sem allir kennarar, eða allir sem kenna á sama skólastigi, purfa að hafa? Er einhver sameiginleg sérfræðipekking sem liggur fagmennsku kennara til grundvallar eða byggist fagmennska peirra einkum á pekkingu á einstökum kennslugreinum og hollustu við gildi starfsins?

Degar opinber skólakerfi tóku að vaxa á nítjándu öld og skólaskylda var tekin upp í löndum Evrópu og Norður-Ameríku voru víða stofnaðir kennaraskólar á framhaldsskólastigi. Seint á nítjándu öld urðu til dæmis til fjölmargir skólar í Bandaríkjunum sem kölluðust normalskólar (e. normal schools) og höfðu pað meginhlutverk að mennta barnakennara. Svipaða sögu er að segja frá mörgum Evrópulöndum par sem kennaraskólar voru á framhaldsskólastigi og burtfararpróf frá beim veitti yfirleitt ekki rétt til inngöngu í háskóla. Hér á landi var til að mynda stofnaður kennaraskóli 1908, árið eftir að Alpingi setti lög um fræðslu barna. Áður hafði um árabil verið boðið upp á stutt kennaranám við Flensborgarskóla (Loftur Guttormsson, 2008b; Gunnar M. Magnúss, 1939). Menntun kennara var víða um lönd skipað skör neðar en menntun háskólastétta fram um 1970 og lengst af var hún víðast hvar mest almenn menntun í kennslugreinum fremur en sérstökum menntavísindum (Carr, 2014; Labaree, 2008; Robinson, 2017).

Degar kennaramenntun færðist loks á háskólastig var reynt að skipuleggja hana sem akademískt nám sem færði nemendum djúpan skilning á skólastarfi, námi og kennslu. Meðal sameiginlegra námsgreina fyrir kennaraefni sem víða var lögð áhersla á við nýstofnaðar kennaradeildir háskóla á árunum kringum 1970 voru sálfræði, félagsfræði, heimspeki og saga. Dví fór pó fjarri að til yrði nein almennt viðurkennd námskrá fyrir kennaranám og síðasta aldarfjórðung hefur víða verið lögð meiri áhersla á kennslutækni og annað efni sem talið er hagnýtt en akademísk fræði sem ætlað er að færa kennurum djúpan skilning á starfi sínu (McAllister, 2015). Nú, hálfri öld eftir að kennaranám færðist á háskólastig, er lítið samkomulag um hvert innihald pess skuli vera (Hargreaves, 2007; Ball og Forzani, 2009; Robinson, 2017; Sockett, 2019). Pað er til marks um petta að í nýlegu greinasafni um heimspekilegar forsendur kennaramenntunar segir í inngangi að um allar jarðir sé kennaramenntun á hverfanda hveli eða „,in a state of flux“ eins og pað er orðað í textanum (Orchard og Oancea, 2015).

Dótt nám kennara hafi víðast verið á framhaldsskólastigi fram yfir miðja síðustu öld hófst flutningur kennaramenntunar á háskólastig pegar á nítjándu öld. Fáeinum normalskólum í Bandaríkjunum var til dæmis breytt í háskóla (e. colleges) fyrir aldamótin 1900. Í lok nítjándu aldar var líka stofnað til prófessorsembætta í uppeldis- og kennslufræðum við nokkra virðulega rannsóknarháskóla par í landi, til dæmis við Columbia, Berkeley, Harvard og Chicago-háskóla (Labaree, 2008). Togstreita um kennaramenntun á okkar tímum á sér sögu sem rekja má til pessa tíma pegar pað gerðist samtímis að fyrstu kennaraskólarnir færðust á háskólastig og eldri háskólar tóku að stunda rannsóknir í menntavísindum. Рað stóð í stappi um hverjir öfluðu gildrar og áreiðanlegrar bekkingar sem nýta mætti til að skipuleggja skólastarf og stjórna pví og í peirri rimmu höfðu gömlu og virðulegu háskólarnir talsvert betri stöðu en peir sem höfðu til skamms tíma verið á framhaldsskólastigi.

Ellen Condliffe Lagemann, sem pekkt er fyrir rannsóknir sínar á sögu menntavísinda, sagði í grein sem birtist 1989 að engin leið væri að skilja átök um petta efni á seinni tímum án pess að gera sér grein fyrir pví að Edward L. Thorndike vann og John Dewey tapaði (Lagemann, 1989). 
Hún bætti pví svo við nokkrum árum seinna að sigur Thorndikes hefði hvorki verið endanlegur né alger (Lagemann, 2000). Fleiri hafa tekið í sama streng og sagt að skólakerfið fylgi Thorndike á borði pótt tekið sé undir með Dewey í orði (Fesmire, 2015; Garrison og O’Quinn, 2004).

\section{Thorndike og Dewey}

Átökin milli Thorndikes og Deweys, sem Lagemann vísar til, snerust að verulegu leyti um eðli menntavísinda og kennslufræðilegrar pekkingar. Thorndike, sem var prófessor við Columbia-háskóla í New York, var einn af forsprökkum sálfræðilegrar atferlishyggju í byrjun síðustu aldar. Hann taldi að nothæf pekking á námi og kennslu yrði til við rannsóknir sálfræðinga. Líkt og fleiri menntavísindamenn við virta rannsóknarháskóla, eins og til dæmis Bobbit sem frá sagði í níunda kafla, taldi hann að slíkar rannsóknir væru ekki á færi kennara. Deir skyldu læra að beita aðferðum og kennslutækni sem vísindamenn sæju um að móta og sannreyna. Vísindalegar undirstöður kennarastarfsins skyldu samkvæmt pessu lagðar af öðrum en kennurunum sjálfum.

Dewey, sem einnig var prófessor við Columbia-háskóla, andmælti pessu og pau andmæli birtast víða í verkum hans, meðal annars í Lýdreði og menntun frá 1916 og í ritgerð um menntavísindi (,The Sources of a Science of Education“) sem birtist prettán árum síðar eða 1929 (Dewey, 19761983, 9. bindi, 1981-1990, 5. bindi, bls. 1-40). Dessi andmæli eru flókin og tengjast erfiðum ráðgátum innan pekkingarfræði og vísindaheimspeki en í stuttu máli má segja að Dewey hafi hafnað pví að til væru nein vísindi sem dygðu til að segja kennurum fyrir verkum. Að hans dómi burfa kennarar sjálfir að glíma við vandamál sem upp koma í starfi peirra og nýta til pess pekkingu úr mörgum áttum, ekki aðeins einni undirstöðugrein (Atli Harðarson, 2016). Í samræmi við petta mælti Dewey með kennaramenntun sem færði fólki fræðilega pekkingu á mörgum sviðum og var par með undanfari peirra sem reyndu að móta akademíska námskrá fyrir kennaramenntun á árunum í kringum 1970. Hann var líka undanfari peirra sem stunda starfendarannsóknir og telja að ekki sé rétt að draga skörp skil milli pess að kenna og að afla pekkingar um nám og kennslu (McKernan, 1996). Thorndike á hins vegar eftirmenn nú um stundir sem tala um gagnreyndar aðferðir og telja meira vit að kennarar læri að beita peim heldur en að verða sjálfir færir um að stunda rannsóknir og próa starfsgrein sína.

Dessi ólíku viðhorf til kennslufræðilegrar pekkingar tengdust stjórnmálum pess tíma. Í byrjun síðustu aldar voru flestir kennarar í bandarískum barnaskólum konur en háskólamennirnir sem töldu sig sérfræðinga um nám og kennslu voru karlar upp til hópa og mörgum pótti sjálfsagt að peir hefðu vit fyrir konunum (Lagemann, 2000). Hér var Dewey á öðru máli enda í liði með femínistum pess tíma og talsmaður jafnréttis.

Átökin snerust um fleira en jafnrétti karla og kvenna. Öld tækninnar var gengin í garð og fleiri og fleiri unnu við fjöldaframleiðslu og iðnað par sem verkafólk fylgdi fyrirmælum sérfræðinga. Dewey hafði áhyggjur af afdrifum lýðræði í pessu samfélagi sem var að verða til, par sem fólk hafði ekki stjórn á vinnu sinni og nýtti ekki eigin skynsemi á vettvangi dagsins. Í grein frá 1903 um lýðræði í menntakerfinu (,Democracy in Education“) sagði hann:

Hvað merkir lýðræði annað en að einstaklingur eigi pátt 1 ákvörðunum um eigin vinnu og að hvaða marki hún stefnir — og pegar á allt er litið sé vinnan í veröldinni betur af hendi leyst ef ólíkir einstaklingar samstilla sjálfir krafta sína heldur en pegar fáir skipuleggja og stjórna öllum hinum, og má pá einu gilda hve vitrir og velviljaðir pessir fáu eru.

(Dewey, 1976-1983, 3. bindi, bls. 234-235)

Í samræmi við petta áleit Dewey heppilegt að kennarar stjórnuðu vinnu sinni og tækju sjálfir ákvarðanir um hvaða pekkingu skyldi beitt til að ná árangri (Atli Harðarson, 2018b). Hann mælti raunar með pví að kennurum yrði treyst sem fagmönnum og taldi að peir yrðu sjálfir að axla ábyrgð á störfum sínum. Hann hafði pó svo sem ekki, frekar en aðrir, skýr og sannfærandi svör við spurningum um hvað kennarar pyrftu helst að læra í sínu kennaranámi til pess að geta petta. 


\section{Siðfræði og fagmennska}

Eins og nefnt var í byrjun pessa kafla er fagstéttum treyst til að vinna sjálfstæett og traustið hvílir á tveimur forsendum. Önnur forsendan er sérfræðileg pekking og hin er hollusta við gildi starfsins. Degar stétt gerir tilkall til að vera álitin fagstétt er eins og hún segi við samfélagið: „Treystið okkur fyrir pessu starfi. Við höfum pekkingu til að annast pað og við virðum pau verðmæti og gildi sem eru í húfi.“ Pessi verðmæti og gildi eru ólík hjá ólíkum starfsgreinum. Læknar huga аð heilbrigði, rafvirkjar að öryggi, proskapjálfar að mannlegri reisn, lögfræðingar að réttlæti, kennarar að menntun.

Hluti af viðleitni starfsstétta til að öðlast viðurkenningu sem fagmenn birtist í skráningu á siðareglum par sem stéttin áréttar að sér sé treystandi, hún láti stjórnast af almannahag eða hag skjólstæðinga sinna og beri sjálf ábyrgð á að starfshættir sínir séu í samræmi við gott siðferði. Siðareglur fagstétta byrja yfirleitt á að tilgreina frumskyldur starfsins með pví að segja hvað fagmaður á einkum að leitast við að gera og er kjarni fagmennskunnar. Í fyrstu greinunum í siðareglum lögmanna, lækna og kennara segir til dæmis:

- Lögmanni ber að efla rétt og hrinda órétti (Lögmannafélag Íslands, e.d.).

- Lækni ber að virða mannslíf og mannhelgi. Læknir skal leitast við að hjálpa heilbrigðum til að varðveita heilsu sína og sjúkum til að öðlast heilbrigði að nýju (Embætti landlæknis, e.d.).

- Kennari menntar nemendur (Kennarasamband Íslands, e.d.).

Í framhaldi af ákvæði um pá frumskyldu að mennta nemendur innihalda siðareglur kennara viðmið sem tengjast réttlátu og farsælu skólasamfélagi par sem meðal annars er rætt um að sýna nemendum virðingu, skapa góðan starfsanda, hafa jafnrétti að leiðarljósi og vinna gegn fordómum, einelti og öðru ranglæti. Dar á eftir koma svo skyldur við starfsgreinina og stéttina par sem tekið er fram að kennari eigi að viðhalda starfshæfni sinni og auka hana. Í pessu felast fyrirheit um að stéttin axli, að minnsta kosti að hluta til, ábyrgð á að afla peirrar pekkingar sem parf til að vinna starfið betur. Hún kveðst kunna fótum sínum forráð.

Dótt hér sé gerður greinarmunur á pekkingu og hollustu við gildi starfsins er rétt að hafa pann fyrirvara á að petta er sampætt eins og Sigurður Kristinsson bendir á í bók sinni um siðareglur starfsgreina par sem hann segir: „Tæknileg kunnátta og siðferðilegt hyggjuvit eru tvær hliðar á sama máli: Hæfninni til að leysa verk sín vel af hendi“" (Sigurður Kristinsson, 1991, bls. 28). Við getum hugsað okkur sem dæmi að kennari geti náð einhverjum námsmarkmiðum með ranglátum refsingum, háði eða öðrum aðferðum sem eru siðferðilega ótækar. Við teljum pó kunnáttu í slíkum aðferðum ekki hluta af peirri sérfræðipekkingu sem réttlætir að stéttinni sé treyst til að vinna sjálfstætt. Hvað telst gild pekking í pessu sambandi ræðst að nokkru af siðferðilegum viðmiðum.

Dótt pað sé tæpast umdeilt að fagmennska kennara byggist á góðu siðferði, sanngirni í garð nemenda og hollustu við gildi starfsins er pað undantekning fremur en regla að siðfræði sé hluti af kennaranámi (Warnick og Silverman, 2011; Campbell, 2011; Maxwell o.fl., 2016). Allmargir fræðimenn hafa rökstutt að petta sé miður og að pjálfun í siðfræðilegri rökræðu ætti að vera hluti af fagmenntun kennara (Carr, 2003, 2007; Campbell, 2011; Dunne, 2011; Higgins, 2011, 2015; Cooke og Carr, 2014; Biesta, 2015).

Veigamestu rökin fyrir mikilvægi siðfræði í kennaranámi eru á pá leið að í skólastarfi hljóti ólík gildi stundum að togast á. Til dæmis geta námskröfur og gildi sem eru innbyggð í námsgreinar togast á við ýmislegt sem varðar jöfnuð og velferð nemenda og einnig geta réttindi einstaklinga ýtt undir eitthvað sem ekki er gott fyrir hag alls skólasamfélagsins. Til að meta hvað er réttast og best að gera undir slíkum kringumstæðum parf vitsmunalega getu til að rökræða og yfirvega verðmæti og gildi. Mér finnst vel líklegt að siðfræðikennsla sé besta leiðin til að efla slíka getu en útiloka ekki að aðrar leiðir geti líka gagnast. Hvað sem rétt er í pessum efnum er að minnsta kosti 
ljóst að pessi rök fyrir mikilvægi siðfræði í kennaranámi gera ráð fyrir að kennarar purfi að starfa sem fagmenn og bera ábyrgð á ákvörðunum um skólastarf. Hyggindi koma að litlum notum ef menn eiga einungis að vinna eftir fyrirmælum, fylgja verklagsreglum og pjóna markmiðum sem aðrir ákveða.

Í bók sem út kom árið 2011 gagnrýnir bandaríski heimspekingurinn Chris Higgins útbreiddar hugmyndir um siðferði kennara og fleiri umönnunarstétta og segir að pær geri nánast ráð fyrir að pessar stéttir fórni sér fyrir skjólstæðinga sína. Fagmenn purfa, segir Higgins, líka að styrkja sjálfa sig og efla - vaxa í starfi. Deir purfa að „viðhalda starfshæfni sinni““ eins og pað er orðað í siðareglum Kennarasambands Íslands.

Samkvæmt Higgins snýst gott kennarasiðferði ekki síst um hvernig fólk geti lifað góðu lífi sem kennarar. Hann veltir fyrir sér hvort petta sé yfirleitt mögulegt eða hvort kennsla hljóti að vera strit par sem kennarinn fórnar sér fyrir aðra. Hann bendir á að slíkar mannfórnir séu algengar og að pað sé oft besta fólkið sem kulnar í starfi vegna pess að pað geri allt fyrir aðra en fái lítið út úr pví sjálft. Hann bendir líka á að álag á kennara sé fremur mikið, peir hafi fæestir eigin skrifstofu par sem er hlé frá áreiti og peir fái sjaldan námsorlof eđa ámóta tækifæri til að ná sér á strik. Sú hugmynd að kennarar séu aðeins pjónar og líf peirra snúist um að hjálpa öðrum gengur ekki upp, segir Higgins, pví sú hjálp sem peim er ætlað að veita „verður aðeins veitt af próttmiklum einstaklingum“ (Higgins, 2011, 5. kafli).

Higgins bendir sem sagt á að siðferði kennara tengist faglegu sjálfstæði peirra á fleiri vegu en pann einn að peir beri ábyrgð á að vinna í págu nemenda sinna og eigi sjálfir að finna leiðirnar til pess. Dað tengist líka sjálfstæði sem gerir kennurum mögulegt að njóta sín í starfi og eflast með pví að vera sjálfs sín ráđandi.

Ábendingar Higgins eru að mínu viti parfar enda er pað gömul saga og ný að kennsla er lýjandi starf. Í erindi um fræðslumál sem Magnús Helgason flutti eftir messu í Hrepphólakirkju árið 1917 svaraði hann peim sem töldu pá að barnakennsla væri lítið starf, sagði að sú skoðun væri „fávizkan einber" og bætti við:

Um petta get ég talað af reynslu. Ég hefi staðið við orf í 12 tíma á dag, og mér er nær að halda, að ég hafi ekki slegið öllu minna seinasta tímann en pann fyrsta - að fráteknum fyrstu dögunum. Ég hefi líka kennt 6 st. á dag, og pað er víst, að ef ég hefði átt að gera pað dag eftir dag, pá myndi ég hafa kennt miklu ver pann síðasta en fyrsta. Ég pekki ekki vinnu, sem preytir eins mikið, einkum ef mörgum er kennt saman. Dví er kennurum víða bannað að kenna yfir 5-6 st. á dag, og pó ekki í striklotu. (Magnús Helgason, 1934, bls. 220-221)

Ég held að nú sé heyskapur allmiklu léttari vinna en hann var árið 1917. Sama má segja um mörg önnur störf par sem vélar hafa létt mönnum lífið. Kennsla er bó trúlega fullt eins erfið nú og hún var fyrir hundrad árum.

\section{Til umhugsunar}

Allt frá pví Dewey og Thorndike tókust á í byrjun síðustu aldar hafa togast á andstæðar hugmyndir um eðli kennarastarfsins. Eftirmenn Deweys hafa lagt áherslu á mikilvægi pess að kennarar nýti eigin reynslu og pekkingu til að bæta starf sitt og hafi stjórn á eigin vinnu. Eftirmenn Thorndikes leggja hins vegar áherslu á að kennarar nýti niðurstöður vísindalegra rannsókna og haldi sig við aðferðir sem vísindamenn hafa sannreynt að virki.

Dótt pessi reipdráttur hafi staðið lengi er enn ekki í sjónmáli neitt samkomulag um hvar hinn gullni meðalvegur liggur milli pess að láta kennurum algerlega eftir að stjórna pví hvað peir kenna og hvernig og pess að stjórna kennslunni ofan frá í smæstu smáatriðum með námskrám, 
námsefni og samræmdu námsmati. Dessi millivegur er vandfundinn meðal annars vegna pess að við vitum of lítið um hvaða áhrif faglegt sjálfstæði, eða ósjálfstæði, kennara hefur á nemendur.

Dað er sama hvað kennari kennir, hann er alltaf að einhverju marki fyrirmynd. Hann er meðal peirra fullorðnu sem börnin umgangast mest. Ef starf hans er ekki slíkt klúður að nemendur sjái hann sem víti til varnaðar pá sýnir hann peim væntanlega með breytni sinni og hátterni hvernig á að vera fullorðin manneskja.

Á seinni hluta síðustu aldar skrifaði Maxine Greene $(1973,1978,1988)$ merkilegar bækur um kennslu par sem hún velti pessu fyrir sér og sagði meðal annars eitthvað á pá leið að kennarar sem æsktu frelsis fyrir sig væru ef til vill einu kennararnir sem ýttu við nemendum pannig að peir lærðu að sækjast eftir frelsi (Greene, 1988). Hin hliðin á pessu er að ósjálfstæður kennari kennir nemendum sínum að vera ósjálfstæðir hvort sem hann ætlar sér pað eður ei. Ef petta er rétt, eins og sumar rannsóknir benda til að pað sé (Pelletier og Sharp, 2009; Hafdís Ingvarsdóttir, 2018) að börn verði ekki sjálfstæð nema pau alist upp innan um fullorðið fólk sem vinnur sjálfstætt - pá er eitthvað pverstæðukennt við skólakerfi sem ætlast í senn til að kennarinn fylgi fyrirmælum og að hann ali upp frumkvöðla.

a) Er kennurum treyst til að vinna sjálfstætt vegna pess að peir hafa sérfræðipekkingu og virða gildi starfsins? Ef ekki, er pá rétt að kalla pá fagmenn?

b) Нvað parf að læra til að verða góður kennari?

c) Er eitthvað sem góðir kennarar hafa til að bera og er ekki hægt að læra í háskóla?

d) Er eitthvað sem fólk kann en getur ekki kennt öðrum nema kunna líka kennslufræði?

e) Verða menn betur færir um að kenna ef peir glíma við spurningarnar sem eru aftan við kaflana í pessari bók? 


\section{Eftirmáli - griðastaður pess seinlega}

Á eftir hverjum kafla í pessari bók eru spurningar sem lesanda er eftirlátið að svara. Við flestum peirra eru trúlega engin svör til sem hægt er að staðfesta svo öllum líki. Pað breytir ekki pví að afstaða til peirra hefur áhrif á stjórn skóla og stefnumótun í menntamálum og pess vegna parf að hugsa og ræða um pær.

Mín eigin afstaða til pessara spurninga hefur að nokkru mótast af starfsreynslu. Ég var kennari við framhaldsskóla frá 1986 til 2001 og skólastjórnandi frá 2001 til 2014. Á pessu tímabili tók ég líka pátt í störfum kennarafélaga, námsefnisgerð og ýmsum nefndum og ráđum frá Samstarfsnefnd um endurmenntun framhaldsskólakennara til Siðaráðs Kennarasambands Íslands. Afstaða mín hefur líka mótast af lestri, rannsóknum og skrifum um heimspekileg efni, ekki síst tilraunum til að skilja pað sem John Dewey skrifaði um menntun fyrir um pað bil einni öld. Áhrifin frá Dewey eru líka óbein pví aðrir fræðimenn sem ég sæki mest til nýttu sér rit hans. Detta á til dæmis við um Lawrence Stenhouse, Maxine Greene og Philip W. Jackson. Ef til vill litar pað líka sýn mína á efnið að ég á farsæla skólagöngu að baki. Mér pótti yfirleitt leikur að læra allt frá pví ég byrjaði í skóla 7 ára gamall og ég slapp við flest af pví versta sem spillir skólagöngu ungs fólks.

Til að lýsa afstöðu minni í stuttu máli er líklega best að segja fyrst að ég held að vísindi, fræði, listir, tækni og ípróttir séu meðal pess besta sem mannkynið á í sameiginlegri eigu sinni. Ég held líka að pegar best lætur geti skólar bæði ávaxtað petta ríkidæmi og gefið nemendum sínum hlutdeild í pví, en menntun sem miðar að slíkri hlutdeild tekur langan tíma. Dað er ekki hægt að verða vel læs, nema tungumál, temja sér stærðfræðilega hugsun, venjast á rökræður um fræðileg efni, verða góður í íprótt eða handverki eða öđlast skilning á náttúrunni, sögunni og samfélaginu í neinum fljótheitum. Hins vegar purfa fæstir að ganga í skóla til að læra að strjúka spjaldtölvur, reima skó, setja í pvottavél eða sitja reiðhjól. Рað sem er fljótlært geta flestir numið án pess að reknar séu dýrar stofnanir.

Skólar gegna vissulega mörgum hlutverkum en eitt af peim mikilvægustu er að vera staður par sem er slaki á tímanum og hægt að gefa sig að ýmsu sem er í eðli sínu seinlegt og gengur fólki úr greipum ef pað reynir að flýta sér.

Íslenska orðið skóli er komið af grísku orði ( $\sigma \chi 0 \lambda n ́)$ sem merkir tómstundir. Andstæður pess eru orð yfir annríki, strit og vinnu. Skóli í pessum upprunalega skilningi var tími til að hugsa og rökræða, hlæja og leika sér. Skólar nútímans einkennast samt af tímapressu og kröfum um afköst og árangur. Margt sem er gagnrýnt í pessari bók eru nýjungar - eins og hæfniviðmið sem á að ljúka, samkeppni milli stofnana og árangurstenging á framlögum til skóla - sem vinna gegn pví að skólar geti verið sá griðastaður pess seinlega sem við purfum pví meir á að halda pví meiri sem hraðinn og æðibunugangurinn er allt í kringum okkur. 


\section{Divergent Roads: Philosophy of Education and the Reality of Modern Schools}

This publication is an introduction to the philosophy of education. It contains critical discussions of common assumptions about schools and school education. Chief among these are notions to the effect that: Those who design school curricula have to choose between emphasising traditional subjects and focusing on the interests of children and the good of society; Schools ought to serve the interest of their students or the economy; Educational aims or learning outcomes can successfully guide teaching and learning; Political authorities can improve schools by mandates from above or implementation of economic incentives; Increased schooling makes society more prosperous.

Each of the twelve chapters delineates a conceptual quandary or arguments that pull in different directions and ends with questions for the reader. Most of these questions have to do with the purposes of school education, educational policy and school administration. It is argued that however difficult these questions are, they need to be discussed seriously. Disregarding them leads to improper and blundering administration of educational affairs.

A short description of the twelve chapters follows:

The title of the first chapter is "What are schools for". It draws upon work by several curriculum theorists who distinguish between different curriculum perspectives and asks to what extent they are opposed. This same chapter also poses questions about educational individualism that conceives of teaching and learning as serving the needs of the student rather than the community.

Chapters two and three, entitled "Liberty and subjects" and "Equality and subjects" are also about school curricula. These two chapters introduce several historic thinkers including Locke, Schiller, Tolstoy, Dewey and Bernstein. Some of the questions raised concern the ideals of the enlightenment, on the one hand, and humanism, on the other and some highlight what people need to learn in order to gain control over their lives and to what extent schools reproduce inequality.

Chapter four - "What the economy needs" - discusses claims to the effect that increased schooling makes society more prosperous. It draws upon recent work by Caplan, the US economist, to question such claims.

The fifth chapter "Schooling, education and morality" is a critical investigation of claims commonly made by people who maintain that more schooling makes students better persons. Some of the key ideas discussed in this chapter derive from the works of Rousseau, Tolstoy, Melville and Illich.

Chapters six, seven and eight, entitled "Registering education", "Problems of data driven administration" and "Bureaucracy and privatisation", deal with issues relating to use of standardised data in school administration. In the first of these three chapters, concepts and theories from the works of the US anthropologist James C. Scott are used to explain how centralised collection of data about students and schools simplifies social reality. The second chapter focuses on Goodhart's Law and how it applies to modern schools. The third deals with arguments for and against marketisation, privatisation and increased competition between schools. It is closely related to the other two chapters because when governments contrive to make schools compete, they rely on standardised data about educational outcomes and school efficiency. These three chapters raise questions as to what extent modern bureaucracy and economic incentives are helpful to school practices/programmes and to what extent they are destructive. 
Chapters nine and ten - "Educational aims" and "Different relations between ends and means" - are both about trends in curriculum design, drawn from the work of Bobbitt in the beginning of last century through seminal publications by Tyler, Bloom and Taba to modern notions of outcomes-based education and competence-based curricula. A critical appraisal of these trends draws upon the works of Stenhouse and his reasons to doubt that the whole of school education can be successfully organised as working towards predefined educational outcomes.

The caption of the eleventh chapter is "School reform or school development" presenting a discussion on how government-led attempts to reform schools can hamper their advancement. Drawing upon works by Tyack, Cuban and other scholars who have written about the history of educational reform and Sahlberg's recent criticism of what he calls the Global Education Reform Movement this chapter poses similar questions as chapters six through ten but views them from a different perspective.

The twelfth and final chapter is labelled "Teacher professionalism" and is largely based on arguments that Dewey published a century ago, but also on insights from Carr and others who have studied the ethical dimensions of teaching. This chapter picks up several threads from previous chapters and queries regarding the meaning of top down curriculum design, data driven administration and other ideas about school education and school management to teachers and their work.

Key words: Philosophy of education, modern school systems, curriculum theory.

\section{Um höfund}

Atli Harðarson (atlivh@hi.is) er dósent við Menntavísindasvið Háskóla Íslands. Hann hefur ritað bækur og greinar um heimspeki, bókmenntir og námskrárfræði.

\section{About the author}

Atli Harðarson (atlivh@hi.is) is associate professor at the University of Iceland, School of Education. His publications include works on philosophy, literature and curriculum theory.

\section{Heimildir}

Akker, J. v. d. (2003a). Curriculum perspectives: An introduction. Í J. v. d. Akker, W. Kuiper og U. Hameyer (ritstjórar), Curriculum landscapes and trends (bls. 1-10). Dordrecht: Kluwer Academic Publishers.

Akker, J. v. d. (2003b). Dutch secondary curriculum reform between ideals and implementation. Í J. v. d. Akker, W. Kuiper og U. Hameyer (ritstjórar), Curriculum landscapes and trends (bls. 61-71). Dordrecht: Kluwer Academic Publishers.

Andri Ísaksson. (1983). Námskrárgerð og námskrárfræði. Í Sigurjón Björnsson (ritstjóri), Athöfn og orð:Afmaelisrit helgað Matthíasi Jónassyni áttreðum (bls. 25-44). Reykjavík: Mál og menning.

Aristóteles. (1995). Siðfraði Níkomakkosar (Svavar Hrafn Svavarsson pýddi). Reykjavík: Hið íslenska bókmenntafélag.

Atli Harðarson. (2010a). Skilningur framhaldsskólakennara á almennum námsmarkmiðum. Tímarit um menntarannsóknir, 7, 93-107. Sótt af http://hdl.handle.net/1946/15853

Atli Harðarson. (2010b). Hvaða áhrif hafði aðalnámskráin frá 1999 á bóknámsbrautir framhaldsskóla? Netla - Veftímarit um uppeldi og menntun. Sótt af http://hdl.handle.net/1946/13799

Atli Harðarson. (2011). Húmanisminn, upplýsingin og íslenska stúdentsprófið. Skírnir, 185(1), 123-144.

Atli Harðarson. (2012a). Hugmyndir um námsmarkmið í nýrri aðalnámskrá framhaldsskóla. Skírnir, 186(1), 215-222. 
Atli Harðarson. (2012b). Ný aðalnámskrá framhaldsskóla og gömul námskrárfræði. Uppeldi og menntun, 21(2), 71-90.

Atli Harðarson. (2013). Equality and academic subjects. Journal of Curriculum Studies, 45(2), 119-131. doi:1 $0.1080 / 00220272.2012 .757806$

Atli Harðarson. (2015). Alpjóðleg mannréttindi. Skírnir, 189(2), 444-473.

Atli Harðarson. (2016). Lýðræði og menntun: Hugleiðing um aldargamla bók. Netla - Veftímarit um uppeldi og menntun. Sótt af http://netla.hi.is/greinar/2016/ryn/01_ryn_arsrit_2016.pdf

Atli Harðarson. (2017). Aims of education: How to resist the temptation of technocratic models. Journal of Philosophy of Education, 51(1), 59-72. doi:10.1111/1467-9752.12182

Atli Harðarson. (2018a). The teacher is a learner: Dewey on aims in education. Educational Philosophy and Theory, 50(5), 538-547. doi:10.1080/00131857.2017.1395735

Atli Harðarson. (2018b). The school as a democratic workplace:The political dimension of Dewey's Democracy and education. Education and Culture, 34(1), 3-18. doi:10.5703/educationculture.34.1.0003

Atli Harðarson. (2019a). Teachers' professionalism, trust, and autonomy. Í M. Peters (ritstjóri), Encyclopedia of teacher education. doi:10.1007/978-981-13-1179-6_34-1

Atli Harðarson. (2019b). Að læra að vera frjáls: Фað sem John Locke sagði um uppeldi til sjálfstjórnar. Hugur, 30, 94-109.

Atli Harðarson, Ólafur Páll Jónsson, Róbert Jack, Sigrún Sif Jóelsdóttir og Póra Björg Sigurðardóttir. (2018). Laxdæla saga og siðferðilegt uppeldi í skólum. Sérrit Netlu 2018 - Bókmenntir, listir og grunnpattir menntunar. doi:10.24270/serritnetla.2019.14

Au, W. (2011). Teaching under the new Taylorism: High stakes testing and the standardization of the 21st century curriculum. Curriculum Studies, 43(1), 25-45. doi:10.1080/00220272.2010.521261

Bailey, C. (2010). Beyond the present and the particular: A theory of liberal education. London: Routledge (frumútgáfa 1984).

Ball, D. L. og Forzani, F. M. (2009). The work of teaching and the challenge for teacher education. Journal of Teacher Education, 60(5), 497-511. doi:10.1177/0022487109348479

Barnett, R. (1988). Does higher education have aims? Journal of Philosophy of Education, 22(2), 239-250. doi:10.1111/j.1467-9752.1988.tb00197.x

Barrow, R. (1984). Giving teaching back to teachers: A critical introduction to curriculum theory. Brighton:Wheatsheaf Books Limited.

Barrow, R. (2014). Compulsory common schooling and individual difference. Í M. Papastephanou (ritstjóri), Philosophical perspectives on compulsory education (bls. 23-34). Dortrecht: Springer.

Beck, U. (2010). A god of one's own. Cambridge: Polity Press.

Berglind Rós Magnúsdóttir. (2013). „Að tryggja framboð og fjölbreytileika“: Nýfrjálshyggja í nýlegum stefnuskjölum um námsgagnagerð. Uppeldi og menntun, 22(2), 55-76.

Berlin, I. (2011). The hedgehog and the fox: An essay on Tolstoy's view of history [Kindle DX útgáfa]. Sótt af https://www.amazon.com/

Biesta, G. J. J. (2015). How does a competent teacher become a good teacher? On judgement, wisdom and virtuosity in teaching and teacher education. Í R. Heilbronn og L. Foreman-Peck (ritstjórar), Philosophical perspectives on teacher education (bls. 3-22). Oxford: Wiley Blackwell.

Bloom, B. S. (1956). Taxonomy of educational objectives, the classification of educational goals - Handbook I: Cognitive domain. New York, NY: David McKay Company.

Bobbitt, J. F. (1972). The curriculum. New York: Arno Press (frumútgáfa 1918).

Bogi Th. Melsteð. (1986). Um menningarskóla. Í Bragi Jósepsson (ritstjóri), Dattir úr íslenskri skólasögu (bls. 127-156). Reykjavík: Kennaraháskóli Íslands.

Boisvert, R. D. (1998). John Dewey: Rethinking our time. Albany, NY: State University of New York Press.

Bowen, J. (1981). A history of western education: Volume 3: The modern west, Europe and the new world. London: Methuen. 
Brien, A. (1998). Professional ethics and the culture of trust. Journal of Business Ethics, 17(4), 391-409. doi:10.1023/A:1005766631092

Broddi Jóhannesson. (1978). Lífsstarf og frjáls próun skoðana. Í Broddi Jóhannesson, Jónas Pálsson og Sigríður Valgeirsdóttir, Lífsstarf og kenning: Prjú erindi um uppeldis- og kennslufreði (bls. 7-34). Reykjavík: Iðunn.

Brynjar Ólafsson. (2009). ,... að mennta pá í orðsins sanna skilningi“: Um sögu, próun og stöðu handmennta í grunnskólum á Íslandi 1970-2007. Netla - Veftímarit um uppeldi og menntun. Sótt af http://hdl.handle. net/1946/13982

Campbell,D.T. (1976). Assessing the impact of planned social change. Occasional Paper Series, 8. Sótt af http:// citeseerx.ist.psu.edu/viewdoc/download?doi=10.1.1.170.6988\&rep=rep1\&type $=$ pdf

Campbell, E. (2011). Teacher education as a missed opportunity in the professional preparation of ethical practitioners. Í L. Bondi, D. Carr, C. Clark og C. Clegg (ritstjórar), Towards professional wisdom (bls. 81-93). Farnham: Ashgate.

Caplan, B. (2018). The case against education: Why the education system is a waste of time and money. Princeton, NJ: Princeton University Press.

Carr, D. (2003). Making sense of education: An introduction to the philosophy and theory of education and teaching. London: Routledge.

Carr, D. (2007). Towards an educationally meaningful curriculum: Epistemic holism and knowledge integration revisited. British Journal of Educational Studies, 55(1), 3-20. doi:10.1111/j.1467-8527.2007.00363.x

Carr, D. (2014). Professionalism, profession and professional conduct: Towards a basic logical and ethical geography. Í S. Billett, C. Harteis og H. Gruber (ritstjórar), International handbook of research in professional and practice-based learning (bls. 5-27). Dordrecht: Springer.

Codd, J. (1999). Educational reform, accountability and the culture of distrust. New Zealand Journal of Educational Studies, 34(1), 45-53.

Codd, J. (2005). Teachers as 'managed professionals' in the global education industry: The New Zealand experience. Educational Review, 57(2), 193-206. doi:10.1080/0013191042000308369

Cooke, S. og Carr, D. (2014).Virtue, practical wisdom and character in teaching. British Journal of Educational Studies, 62(2), 91-110. doi:10.1080/00071005.2014.929632

Coulson, A. J. (1999). Market education: The unknown history. New Brunswick, NJ: Transaction Publishers.

Cuban, L. (1992). Curriculum stability and change. Í P.W.Jackson (ritstjórar), Handbook of research on curriculum: A project of the American educational research association (bls. 216-247). New York, NY: Macmillan.

Deneen, P. J. (2018). Why liberalism failed. New Haven, CT:Yale University Press.

Deresiewicz, W. (2014). Excellent sheep: The miseducation of the American elite and the way to a meaningful life [Kindle DX útgáfa]. Sótt af https://www.amazon.com/

Dewey, J. (1976-1983). The middle works of John Dewey 1899-1924, ritstjóri Jo Ann Boydston, bindi I-XV. Carbondale, IL: Southern Illinois University Press.

Dewey, J. (1981-1990). The later works of John Dewey 1925-1953, ritstjóri Jo Ann Boydston, bindi I-XVII. Carbondale, IL: Southern Illinois University Press.

Dewey, J. (2000). Reynsla og menntun (Gunnar Ragnarsson pýddi). Reykjavík: Rannsóknarstofnun Kennaraháskóla Íslands.

Dewey, J. (2010). Dörfin fyrir heimspeki menntunar (Gunnar Ragnarsson pýddi). Í Jóhanna Einarsdóttir og Ólafur Páll Jónsson (ritstjórar), John Dewey í hugsun og verki: Menntun, reynsla og lýðræði (bls. 197-206). Reykjavík: Háskólaútgáfan.

Dóra S. Bjarnason, Hermína Gunnpórsdóttir og Ólafur Páll Jónsson. (2016). Inngangur. Í Dóra S. Bjarnason, Hermína Gunnpórsdóttir og Ólafur Páll Jónsson (ritstjórar), Skóli margbreytileikans: Menntun og manngildi i kjölfar Salamanca (bls. 7-9). Reykjavík: Háskólaútgáfan.

Du Bois, W. E. B. (2015). The souls of black folk [Kindle DX útgáfa]. Sótt af https://www.amazon.com/

Dunne, J. (2011). 'Professional wisdom' in 'practice'. Í L. Bondi, D. Carr, C. Clark og C. Clegg (ritstjórar), Towards professional wisdom (bls. 13-26). Farnham: Ashgate. 
Eisner, E.W. og Vallance, E. (1974). Five conceptions of curriculum: Their roots and implications for curriculum planning. Í E. W. Eisner og E. Vallance (ritstjórar), Conflicting conceptions of the curriculum (bls. 1-18). Berkeley, CA: McCutchan.

Elliott, J. (2007). Making evidence-based practice educational. Í M. Hammersley (ritstjóri), Educational research and evidence-based practice (bls. 66-87). Los Angeles, CA: Sage.

Elliott, J. (2009). Connecting action with research. Í E. C. Short og L. J.Waks (ritstjórar), Leaders in curriculum studies: Intellectual self-portraits (bls. 77-90). Boston, MA: Sense.

Embætti landlæknis. (e.d.). Siðareglur lakna. Sótt af https://www.landlaeknir.is/gaedi-og-eftirlit/heilbrigdisstarfsfolk/starfsleyfi/sidareglur/item13353/

Entwistle, H. (1979). Antonio Gramsci: Conservative schooling for radical politics. London: Routledge \& Kegan Paul.

Fesmire, S. (2015). Dewey. New York, NY: Routledge.

Fitzgerald, T. (2009). The tyranny of bureaucracy: Continuing challenges of leading and managing from the middle. Educational Management Administration E Leadership, 37(1), 51-65. doi:10.1177/1741143208098164

Fjármálaráđuneytið. (1996). Árangursstjórnun í ríkisrekstri: Skýrsla nefndar í nóvember 1996. Sótt af https:// www.stjornarradid.is/media/fjarmalaraduneyti-media/media/arangursstjornun/arangursstjornun1996.pdf

Friedman, M. (1955). The role of government in education. Í R. A. Solo (ritstjóri), Economics and the public interest (bls. 127-134). New Brunswick, NJ: Rutgers University Press.

Furedi, F. (2009). Wasted: Why education isn't educating. London: Bloomsbury.

Garrison, J. og O'Quinn E. J. (2004). Reflections on Whitman, Dewey, and educational reform: Recovering spiritual democracy for our materialistic times. Education and Culture, 20(2), 68-77.

Gatto, J.T. (2017). Dumbing us down. Gabriola Island, Kanada: New Society (frumútgáfa 1992).

Gestur Guðmundsson. (2008). Félagsfreeði menntunar. Reykjavík: Skrudda.

Gibboney, R.A. (1994). The stone trumpet: A story of practical school reform 1960-1990. Albany, NY: State University of New York Press.

Goldstein, D. (2014). The teacher wars: A history of America's most embattled profession [Kindle DX útgáfa]. Sótt af https://www.amazon.com/

Goodhart, C. A. E. (2015). Goodhart's law. Í L. P. Rochon og S. Rossi (ritstjórar), The encyclopedia of central banking (bls. 227-228). Celtenham, UK og Northampton, MA: Edward Elgar.

Gould, S. J. (2006). The mismeasure of man [Kindle DX útgáfa]. Sótt af https://www.amazon.com/ (frumútgáfa 1981).

Graeber, D. (2015). The utopia of rules: On technology, stupidity, and the secret joys of bureaucracy [Kindle DX útgáfa]. Sótt af https://www.amazon.com/

Greene, M. (1973). Teacher as stranger: Educational philosophy for the modern age. Belmont, CA: Wadsworth.

Greene, M. (1978). Landscapes of learning. New York, NY:Teachers College Press.

Greene, M. (1988). The dialectic of freedom. New York, NY: Teachers College Press.

Greene, M. (2001). Variations on a blue guitar: The Lincoln centre institute lectures on aesthetic education. New York, NY:Teachers College Press.

Gretar L. Marinósson og Dóra S. Bjarnason. (2016). Próun skóla margbreytileikans í kjölfar Salamanca-yfirlýsingarinnar. Í Dóra S. Bjarnason, Hermína Gunnpórsdóttir og Ólafur Páll Jónsson (ritstjórar), Skóli margbreytileikans: Menntun og manngildi í kjölfar Salamanca (bls. 11-39). Reykjavík: Háskólaútgáfan.

Guðmundur Finnbogason. (1994). Lýðmenntun. Reykjavík: Rannsóknarstofa Kennaraháskóla Íslands (frumútgáfa 1903).

Guðmundur Heiðar Frímannsson. (2018). Skólar og lýðræði. Um borgaramenntun. Reykjavík: Háskólaútgáfan.

Gunnar M. Magnúss. (1939). Saga alpýðufreðslunnar á Íslandi. Reykjavík: Samband íslenzkra barnakennara.

Hafdís Ingvarsdóttir. (2004). Mótun starfskenninga íslenskra framhaldsskólakennara. Tímarit um menntarannsóknir, 1,39-47. Sótt af http://hdl.handle.net/1946/14332

Hafdís Ingvarsdóttir. (2007). Samskipti kennara og nemenda: Hindrun og/eða hvati í breytingastarfi. Í Gunnar Dór Jóhannesson (ritstjóri), Rannsóknir í félagsvísindum VIII: Félagsvísindadeild: Erindi flutt á rádstefnu í desember 2007 (bls. 371-380). Reykjavík: Félagsvísindastofnun Háskóla Íslands. 
Hafdís Ingvarsdóttir. (2018). Kennsluhæettir speglaðir í ljósi sjálfræðis:Virðing, ábyrgð og traust. Sérrit Netlu 2018 - Framhaldsskólinn í brennidepli. doi:10.24270/serritnetla.2019.3

Hallgrímur Pétursson. (1931). Sálmar og kvæði. Reykjavík: Prentsmiðja Jóns Helgasonar.

Hamilton, D. (1989). Towards a theory of schooling. London: The Falmer Press.

Hamilton, D. (1990). Learning about education. Milton Keynes: Open University Press.

Hargreaves, D. (2007). Teaching as a research-based profession: Possibilities and prospects (The Teacher training agency lecture 1996). Í M. Hammersley (ritstjóri), Educational research and evidence-based practice (bls. 3-17). Los Angeles, CA: Sage.

Helgi Skúli Kjartansson. (2008). Kennarastéttin. Í Loftur Guttormsson (ritstjóri), Almenningsfraðsla á Íslandi 1880-2007: Síđara bindi, skóli fyrir alla 1946-2007 (bls. 198-215). Reykjavík: Háskólaútgáfan.

Hermansen, H. (2017). Knowledge relations and epistemic infrastructures as mediators of teachers' collective autonomy. Teaching and Teacher Education, 65, 1-9. doi:10.1016/j.tate.2017.03.003

Higgins, C. (2011). The good life of teaching:An ethics of professional practice [Kindle DX útgáfa]. Sótt af https:// www.amazon.com/

Higgins, C. (2015). Why we need a virtue ethics of teaching. Í R. Heilbronn og L. Foreman-Pack (ritstjórar), Philosophical perspectives on teacher education (bls. 57-75). Chichester:Wiley-Blackwell.

Hinchliffe, G. (2014). Education, liberty and authority. Í M. Papastephanou (ritstjóri), Philosophical perspectives on compulsory education (bls. 35-48). Dortrecht: Springer.

Holt, M. (2009). The scenic route. Í E. C. Short og L.J.Waks (ritstjórar), Leaders in curriculum studies: Intellectual self-portraits (bls. 105-116). Boston, MA: Sense.

Howlett, J. (2013). Progressive education: A critical introduction. London: Bloomsbury Academic.

Hoyle, E. (1982). The professionalization of teachers: A paradox. British Journal of Educational Studies, 30(2), 161-171. doi:10.1080/00071005.1982.9973622

Illich, I. (1995). Deschooling society [Kindle DX útgáfa]. Sótt af https://www.amazon.com/

Ingveldur Geirsdóttir. (2018, 18. apríl). Snýst um fjármuni ríkisins og jöfn réttindi sjúklinga. Morgunblađið, bls. 6.

Jackson, P. W. (1990). Introduction. Í J. Dewey, The school and society and The child and the curriculum [Kindle DX útgáfa]. Sótt af https://www.amazon.com/

Jackson, P.W. (1992). Conceptions of curriculum and curriculum specialists. Í P.W. Jackson (ritstjóri), Handbook of research on curriculum: A project of the American Educational Research Association (bls. 3-40). New York, NY: Macmillan.

Jón Birgir Eiríksson. (2019, 23. febrúar). Segist ekki hafa vistað nein gögn. Morgunblaðið, bls. 4.

Jón Espólín. (1982). Frá Montesquieu, Rousseau og Voltaire. Í Ingi Sigurðsson (ritstjóri), Upplýsing og saga: Sýnisbók sagnaritunar Íslendinga á upplýsingaröld (bls. 168-170). Reykjavík: Rannsóknarstofnun í bókmenntafræði og Menningarsjóður.

Jón F. Hjartarson. (1990). Framhaldsskólinn á tímabili lögleysunnar 1974-1990. Í Jón F. Hjartarson og Ólafur S.Ásgeirsson (ritstjórar), Jarteinabók Jóns Böðvarssonar: Afmalisrit helgað Jóni Böðvarssyni sextugum, 2. maí 1990 (bls. 25-44). Reykjavík: Iðnskólaútgáfan.

Jónas Pálsson. (1983). Störf kennara í grunnskólum. Í Sigurjón Björnsson (ritstjóri), Athöfn og orð: Afmalisrit helgað Matthíasi Jónassyni áttræðum (bls. 115-136). Reykjavík: Mál og menning.

Karseth, B. (2006). Curriculum restructuring in higher education after the Bologna process: A new pedagogic regime? Revista Española de educación comparada, 12, 255-284.

Katz, M. S. og Denti, L. G. (1996). The road to nowhere begins with where we are: Rethinking the future of American education. Interchange, 27(3-4), 261-277. doi:10.1007/BF01807408

Kellough, R. D. og Kellough, N. G. (2007). Secondary school teaching: A guide to methods and resources. Upper Saddle River, NJ: Pearson/Merrill Prentice Hall.

Kennarasamband Íslands. (e.d.). Siðareglur kennara. Sótt af https://www.ki.is/um-ki/stefna/sidareglur

Kennedy, D., Hyland,Á. og Ryan, N. (2006). Writing and using learning outcomes:A practical guide. Grein C 3.4-1. Í E. Froment, J. Kohler, L. Purser og L. Wilson (ritstjórar), EUA Bologna handbook - Making Bologna work. Berlin: Raabe Verlag. 
Klein, M. F. (2009). Pivotal events and people in my career. Í E. C. Short og L. J.Waks (ritstjórar), Leaders in curriculum studies: Intellectual self-portraits (bls. 117-128). Boston, MA: Sense.

Kliebard, H. M. (1987). The struggle for the American curriculum 1893-1958. London: Routledge \& Kegan Paul.

Kotzee, B. (2018). Dewey as virtue epistemologist: Open-mindedness and the training of thought in Democracy and education. Journal of Philosophy of Education, 52(2), 359-373. doi:10.1111/1467-9752.12291

Kristinn Ármannsson, Einar Magnússon, Guðni Guðmundsson og Heimir Porleifsson. (1975). Saga Reykjavíkurskóla 1: Nám og nemendur. Reykjavík: Sögusjóður Menntaskólans í Reykjavík.

Kristjana Stella Blöndal, Jón Torfi Jónasson og Anne-Christine Tannhäuser. (2011). Dropout in a small society: Is the Icelandic case somehow different? Í S. Lamb, E. Markussen, R. Teese, N. Sandberg og J. Polesel (ritstjórar), School dropout and completion: International comparative studies in theory and policy (bls. 233-251). London: Springer.

Kristján Kristjánsson. (2015). Aristotelian character education. New York, NY: Routledge.

Kristján Kristjánsson. (2018). Virtuous emotions. Oxford: Oxford University Press.

Labaree, D. (2008). An uneasy relationship: The history of teacher education in the university. Í M. Cochran-Smith, S. Feiman-Nemser og J. McIntyre (ritstjórar), Handbook of research on teacher education (bls. 290-306). New York, NY: Routledge.

Lagemann, E. C. (1989). The plural worlds of educational research. History of Education Quarterly, 29(2), 183-214. doi:10.2307/368309

Lagemann, E. C. (2000). An elusive science:The troubling history of education research. Chicago, IL:The University of Chicago Press.

Laozi. (2010). Ferlið og dygðin (Ragnar Baldursson býddi). Reykjavík: Hið íslenska bókmenntafélag.

Lingard, B., Martino, W., Rezai-Rashti, G. og Sellar, S. (2016). Globalizing educational accountabilities. New York, NY: Routledge.

Locke, J. (1989). Some thoughts concerning education. Oxford: Clarendon Press.

Locke, J. (1993a). Ritgerð um ríkisvald (Atli Harðarson pýddi). Reykjavík: Hið íslenska bókmenntafélag.

Locke, J. (1993b). Of the conduct of the understanding. Bristol: Thoemmes Press.

Loftur Guttormsson. (2008a). Sjálfsprottnir skólar. Í Loftur Guttormsson (ritstjóri), Almenningsfraðsla á Íslandi 1880-2007: Fyrra bindi, skólahald i ba og sveit 1880-1945 (bls. 56-71). Reykjavík: Háskólaútgáfan.

Loftur Guttormsson. (2008b). Barnakennarar: Starfskjör, menntun og staða. Í Loftur Guttormsson (ritstjóri), Almenningsfreðsla á Íslandi 1880-2007: Fyrra bindi, skólahald í ba og sveit 1880-1945 (bls. 126-141). Reykjavík: Háskólaútgáfan.

Lowe, R. (2007). The death of progressive education: How teachers lost control of the classroom. New York, NY: Routledge.

Lög um framhaldsskóla nr. 57/1988.

Lög um framhaldsskóla nr. 80/1996.

Lög um lögmenn nr. 77/1998.

Lög um lögverndun á starfsheiti og starfsréttindum grunnskólakennara, framhaldsskólakennara og skólastjóra nr. 48/1986.

Lög um persónuvernd og vinnslu persónuupplýsinga nr. 90/2018.

Lögmannafélag Íslands. (e.d.). Siðareglur lögmanna. Sótt af https://lmfi.is/lmfi/log-og-reglur-um-logmenn/ sidareglur-logmanna

Magnús Helgason. (1919). Uppeldismál: Til leiðbeiningar barnakennurum og heimilum. Reykjavík: Gutenberg.

Magnús Helgason. (1934). Skólarææur og önnur erindi. Reykjavík: Samband íslenzkra barnakennara.

Mannréttindayfirlýsing Sameinuðu pjóðanna. (e.d.). Sótt af https://www.un.is/stadreyndir/mannrettindayfirlysing-sameinudu-thjodanna/

Marzano, R. J. og Kendall, J. S. (2008). Designing and assessing educational objectives: Applying the new taxonomy. Thousand Oaks, CA: Corwin Press.

Maxwell, B. (2015). 'Teacher as professional' as metaphor: What it highlights and what it hides. Journal of Philosophy of Education, 49(1), 86-106. doi:10.1111/1467-9752.12106 
Maxwell, B., Tremblay-Laprise, A. A., Filion, M., Boon, H., Daly, C., van den Hoven, M., Heilbronn, R., Lenselink, M. og Walters, S. (2016). A five-country survey on ethics education in preservice teaching programs. Journal of Teacher Education, 67(2), 135-151. doi:10.1177/0022487115624490

McAllister, J. (2015). The idea of a university and a school partnership. Í R. Heilbronn og L. Foreman-Peck (ritstjórar), Philosophical perspectives on teacher education (bls. 38-53). Oxford:Wiley-Blackwell.

McKernan, J. (1996). Curriculum action research: A handbook of methods and resources for the reflective practitioner (2. útgáfa). London: Kogan Page Limited.

McNeil, J. D. (1977). Curriculum: A comprehensive introduction. Boston, MA: Little, Brown.

Melville, H. (2014). Billy Budd, sailor [Kindle DX útgáfa]. Sótt af https://www.amazon.com/

Menntamálaráđuneytið. (1986). Námskrá handa framhaldsskólum: Námsbrautir og áfangalýsingar. Reykjavík: Höfundur.

Menntamálaráðuneytið. (1993). Nefnd um mótun menntastefnu: Áfangaskýrsla. Sótt af https://www.stjornarradid.is/media/menntamalaraduneyti-media/media/ritogskyrslur/nefnd_motun_menntstefn_1993.pdf

Menntamálaráđuneytið. (1994). Nefnd um mótun menntastefnu: Skýrsla. Sótt af https://www.stjornarradid.is/ media/menntamalaraduneyti-media/media/ritogskyrslur/menntastefna_1994.pdf

Menntamálaráduneytið. (1999a). Aðalnámskrá framhaldsskóla: Almennur hluti. Reykjavík: Höfundur.

Menntamálaráđuneytið. (1999b). Aðalnámskrá framhaldsskóla: Íslenska. Reykjavík: Höfundur.

Menntamálaráðuneytið. (1999c). Ađalnámskrá framhaldsskóla: Náttúrufrađi. Reykjavík: Höfundur.

Menntamálaráðuneytið. (1999d). Aðalnámskrá framhaldsskóla: Samfélagsgreinar. Reykjavík: Höfundur.

Menntamálaráđuneytið. (1999e). Aðalnámskrá framhaldsskóla: Starđfraði. Reykjavík: Höfundur.

Menntamálaráðuneytið. (1999f). Ađalnámskrá grunnskóla: Almennur hluti 1999. Reykjavík: Höfundur.

Mennta- og menningarmálaráđuneytið. (2011). Ađalnámskrá leikskóla. Reykjavík: Höfundur.

Mennta- og menningarmálaráđuneytið. (2012). Ađalnámskrá framhaldsskóla 2011: Almennur hluti (2. útgáfa). Reykjavík: Höfundur.

Mennta- og menningarmálaráðuneytið. (2013). Aðalnámskrá grunnskóla: Almennur hluti 2011 og greinasvið 2013. Reykjavík: Höfundur.

Mennta- og menningarmálaráđuneytið. (2014). Hvítbók um umbatur í menntun. Reykjavík: Höfundur.

Mennta- og menningarmálaráðuneytið. (2015). Mat á framkvoemd stefnu um skóla án ađgreiningar: Skýrsla starfshóps. Sótt af https://www.stjornarradid.is/media/menntamalaraduneyti-media/media/frettir2015/ skyyrsla_starfshoops_um_mat_a_menntastefnu_loka.pdf

Menntamálastofnun. (e.d.). Staðfestar námsbrautalýsingar. Sótt af https://mms.is/stadfestar-namsbrautalysingar

Meyvant Dórólfsson, Allyson Macdonald og Eggert Lárusson. (2007). Sýn fimm grunnskólakennara á nám og kennslu í náttúruvísindum. Tímarit um menntarannsóknir, 4, 83-99. Sótt af http://hdl.handle.net/1946/15101

Montaigne, M. d. (1991). The complete essays (M. A. Screech pýddi). London: Penguin Books.

Moore, R. (2013). Basil Bernstein: The thinker and the field. London: Routledge.

Moulin, D. (2014). Leo Tolstoy [Kindle DX útgáfa]. Sótt af https://www.amazon.com/

Muller, J. Z. (2018). The tyranny of metrics. Princeton, NJ: Princeton University Press.

Nussbaum, M. C. (1998). Cultivating humanity: A classical defense of reform in liberal education. Cambridge, MA: Harvard University Press.

Nussbaum, M. C. (2010). Not for profit: Why democracy needs the humanities. Princeton, NJ: Princeton University Press.

OECD. (2011). Labour force statistics 1989-2009. Sótt af https://read.oecd-ilibrary.org/employment/labour-force-statistics-2010_lfs-2010-en-fr

OECD. (2016). PISA 2015 results (volume I): Excellence and equity in education. Sótt af http://www.oecd.org/ education/pisa-2015-results-volume-i-9789264266490-en.htm

OECD. (2018a). Labour force statistics 2008-2017. Sótt af https://read.oecd-ilibrary.org/employment/oecd-labour-force-statistics-2018_oecd_lfs-2018-en 
OECD. (2018b). Education at a glance 2018: OECD indicators. Sótt af https://read.oecd-ilibrary.org/education/ education-at-a-glance-2018_eag-2018-en

O'Hear, A. og Sidwell, M. (2009). The school of freedom: A liberal education reader from Plato to the present day. Exeter: Imprint Academic.

Orchard, J. og Oancea, A. (2015). Preface. Í R. Heilbronn og L. Foreman-Peck (ritstjórar), Philosophical perspectives on teacher education (bls. vii-x). Oxford: Wiley-Blackwell.

Ólafur Páll Jónsson. (2010). Hugsun, reynsla og lýðræði. Í Jóhanna Einarsdóttir og Ólafur Páll Jónsson (ritstjórar), John Dewey í hugsun og verki: Menntun, reynsla og lýdrææi (bls. 13-41). Reykjavík: Háskólaútgáfan.

Ólafur Páll Jónsson. (2014). Lýðræðisleg menntastefna: Sögulegt ágrip og heimspekileg greining. Stjórnmál og stjórnsýsla, 10(1), 99-117. doi:10.13177/irpa.a.2014.10.1.6

Ólafur Sigurðsson. (2008). Reiknilíkan framhaldsskólanna (óútgefin MPA-lokaritgerð). Sótt af http://hdl. handle.net/1946/3385

Páll Skúlason. (1987). Palingar: Safn erinda og greina. Reykjavík: Ergo.

Páll Skúlason. (2014). Háskólapxelingar: Um stefnu og stöðu háskóla í samtímanum. Reykjavík: Háskólaútgáfan.

Pelletier, L. G. og Sharp, E. C. (2009). Administrative pressures and teachers' interpersonal behaviour in the classroom. Theory and Research in Education, 7(2), 174-183. doi:10.1177/1477878509104322

Peters, R. S. (1966). Ethics and education. London: Allen \& Unwin.

Peters, R. S. (1973). Authority, responsibility and education (3. útgáfa). London: George Allen \& Unwin.

Peters, R. S. (1977). John Dewey's philosophy of education. Í R. S. Peters (ritstjóri), John Dewey reconsidered (bls. 102-121). London: Routledge \& Kegan Paul.

Pinar, W. F., Reynolds, W. M., Slattery, P. og Taubman, P. M. (1995). Understanding curriculum: An introduction to the study of historical and contemporary curriculum discourses. New York, NY: Peter Lang.

Platon. (1991). Ríkið (Eyjólfur Kjalar Emilsson pýddi). Reykjavík: Hið íslenska bókmenntafélag.

Popkewitz, T. S., Tabachnick, B. R. og Wehlage, G. (1982). The myth of educational reform: A study of school responses to a program of change. London: The University of Wisconsin Press.

Power, F. C., Higgins, A. og Kohlberg, L. (1989). Lawrence Kohlberg's approach to moral education. New York, NY: Columbia University Press.

Putnam, H. (2004). Ethics without ontology. Cambridge, MA: Harvard University Press.

Ravitch, D. (2013). Reign of error: The hoax of the privatization movement and the danger to America's public schools. New York, NY: Knopf.

Reglugerð um námssamninga og starfspjálfun nr. 280/1997.

Reglugerð um reiknilíkan til að reikna út kennslukostnað framhaldsskóla nr. 335/1999.

Reglugerð um sveinspróf nr. 698/2009.

Reid,W.A. (2006). The pursuit of curriculum: Schooling and the public interest. Greenwich, CT: Information Age.

Robinson, W. (2017). Teacher education: A historical overview. Í D. J. Clandinin og J. Husu (ritstjórar), The SAGE handbook of research on teacher education (bls. 49-67). London: Sage.

Rollyson, C., Paddock, L. og Gentry, A. (2007). Critical companion to Herman Melville: A literary reference to his life and work. New York, NY: Infobase.

Rousseau, J. J. (1964). The first and second discourses (R. D. Masters og J. R. Masters pýddu). New York, NY: St. Martins Press.

Rousseau, J. J. (1991). Emile or on education (A. Bloom pýddi). London: Penguin Books.

Sahlberg, P. (2016). The global educational reform movement and its impact on schooling. Í K. Mundy, A. Green, B. Lingard og A.Verger (ritstjórar), The handbook of global education policy (bls. 128-144). Chichester, UK: John Wiley \& Sons.

Sahlberg, P. (2017). Finnska leiðin 2.0: Hvað getur umheimurinn leert af breytingum í finnska skólakerfinu? (Sigrún Á. Eiríksdóttir pýddi). Reykjavík: Félag grunnskólakennara.

Sarason, S. B. (1971). The culture of the school and the problem of change. Boston, MA:Allyn and Bacon. 
Schwab,J.J. (1978). Science, curriculum, and liberal education: Selected essays (ritstjórar I.Westbury og N.J.Wilkof). Chicago: The University of Chicago Press.

Schiller, F. (2006). Um fagurfradilegt uppeldi mannsins (Arthúr Björgvin Bollason og Dröstur Ásmundsson pýddu). Reykjavík: Hið íslenska bókmenntafélag.

Schiro, M. S. (2008). Curriculum theory: Conflicting visions and enduring concerns. Los Angeles, CA: Sage.

Scott, J. C. (1998). Seeing like a state: How certain schemes to improve the human condition have failed [Kindle DX útgáfa]. Sótt af https://www.amazon.com/

Scott, J. C. (2012). Two cheers for anarchism: Six easy pieces on autonomy, dignity, and meaningful work and play [Kindle DX útgáfa]. Sótt af https://www.amazon.com/

Scott, J. C. (2017). Against the grain: A deep history of the earliest states [Kindle DX útgáfa]. Sótt af https://www. amazon.com

Sen, A. (2011). The idea of justice. Cambridge, MA: Belknap Press of Harvard University Press.

Short, E. C. (2009). Introduction: In anticipation of these essays. Í E. C. Short og L.J.Waks (ritstjórar), Leaders in curriculum studies: Intellectual self-portraits (bls. xvii-xx). Boston, MA: Sense Publishers.

Sigrún Aðalbjarnardóttir. (2007).Virðing og umhyggja: Ákall 21. aldar. Reykjavík: Heimskringla, háskólaforlag Máls og menningar.

Sigurður Kristinsson. (1991). Siðareglur: Greining á siðareglum ásamt skrádum siðareglum starfsgreina á Íslandi. Reykjavík: Rannsóknarstofnun í siðfræði.

Sigurjón Mýrdal. (1992). Hugmyndir um fagmennsku íslenskra kennara. Uppeldi og menntun, 1(1), 297-313.

Sockett, H. (2019). Moral thought in educational practice: The primacy of moral matters for teaching and learning. New York, NY: Routledge.

Stefanía Helga Stefánsdóttir. (2019). Svigrúm tveggja skóla til nýrra leiða i i iðn- og verknámi eftir gildistöku laga um framhaldsskóla nr. 92/2008 (oútgefin meistararitgerð). Sótt af http://hdl.handle.net/1946/34106

Stenhouse, L. (1970). Some limitations of the use of objectives in curriculum research and planning. Paedagogica Europaea, 6, 73-83. doi:10.2307/1502500

Stenhouse, L. (1975). An introduction to curriculum research and development. London: Heinemann.

Strathern, M. (1997). 'Improving ratings': Audit in the British university system. European Review, 5, 305-321. doi:10.1002/(SICI)1234-981X(199707)5:33.0.CO;2-4

Sveinbjörn Egilsson. (1968). Skólareður Sveinbjarnar Egilssonar. Reykjavík: Almenna bókafélagið.

Taba, H. (1962). Curriculum development: Theory and practice. New York: Harcourt, Brace \& World.

Tolstoj, L. (1941-1944). Anna Karenina (Magnús Ásgeirsson og Karl Ísfeld pýddu). Reykjavík: Bókaútgáfa Menningarsjóðs.

Tolstoj, L. (1986). Stríð og friður (Leifur Haraldsson pýddi). Reykjavík: Uglan.

Tolstoy, L. (2010). The death of Ivan Ilych (L. Maude og A. Maude pýddu) [Kindle DX útgáfa]. Sótt af https:// www.amazon.com/

Tooley, J. (2013). The beautiful tree: A personal journey into how the world's poorest people are educating themselves [Kindle DX útgáfa]. Sótt af https://www.amazon.com/

Tooley, J. (2014). E. G. West [Kindle DX útgáfa]. Sótt af https://www.amazon.com/Tyack, D. og Cuban, L. (1995). Tinkering toward utopia: A century of public school reform. Cambridge, MA: Harvard University Press.

Tye, B. B. (2000). Hard truths: Uncovering the deep structure of schooling. New York, NY:Teachers College Press.

Tyler, R. W. (1949). Basic principles of curriculum and instruction. Chicago, IL:The University of Chicago Press.

UNESCO. (2012). International standard classification of education: ISCED 2011. Montreal: UNESCO Institute for Statistics. Sótt af http://uis.unesco.org/sites/default/files/documents/international-standard-classification-of-education-isced-2011-en.pdf

Walker, D. F. og Soltis, J. F. (1997). Curriculum and aims (3. útgáfa). New York, NY:Teachers College Press.

Warnick, B. R. og Silverman, S. K. (2011). A framework for professional ethics courses in teacher education. Journal of Teacher Education, 62(3), 273-285. doi:10.1177/0022487110398002 
West, E. G. (1994). Education and the state. Indianapolis, IN: Liberty Fund (frumútgáfa 1965).

Westbrook, R. B. (1991). John Dewey and American democracy. Ithaca, NY: Cornell University Press.

White, J. (1982). The aims of education restated. New York, NY: Routledge.

White, J. (1997). Philosophical perspectives on school effectiveness and school improvement. The Curriculum Journal, 8(1), 29-44. doi:10.1080/09585176.1997.11070760

White, J. (2004). Conclusion. Í J.White (ritstjóri), Rethinking the school curriculum:Values, aims and purposes (bls. 179-190). London: RoutledgeFalmer.

White, J. (2005). The curriculum and the child: The selected works of John White. London: Routledge.

White, J. (2006). Autonomy, human flourishing and the curriculum. Journal of Philosophy of Education, 40(3), 381-390. doi:10.1111/j.1467-9752.2006.00523.x

White, J. (2009). Why general education? Peters, Hirst and history. Journal of Philosophy of Education, 43(s1), 123-141. doi:10.1111/j.1467-9752.2009.00718.x

Williams, B. (1981). Moral luck: Philosophical papers 1973-1980 [Kindle DX útgáfa]. Sótt af https://www. amazon.com/

Winch, C. (1996). The aims of education revisited. Journal of Philosophy of Education, 30(1), 33-44. doi:10.1111/j.1467-9752.1996.tb00378.x

Winstanley, C. (2012). Alluring ideas: Cherry picking policy from around the world. Journal of Philosophy of Education, 46(4), 516-531. doi:10.1111/j.1467-9752.2012.00876.x

Wolfgang Edelstein. (1988). Skóli, nám, samfélag. Reykjavík: Iðunn.

Woolhouse, R. (2007). Locke: A biography. Cambridge: Cambridge University Press.

Young, M. F. D. (2008). Bringing knowledge back in: From social constructivism to social realism in the sociology of education. London: Routledge.

Young, M. F. D. (2009). What are schools for? Í H. Daniels, H. Lauder og H. Porter (ritstjórar), Knowledge, values and educational policy (bls. 10-18). London: Routledge.

Young, M. F. D. (2010a). Why educators must differentiate knowledge from experience. Journal of the Pacific Circle Consortium for Education, 22(1), 9-20. Sótt af https://programs.crdg.hawaii.edu/pcc/PAE_22_1_final_10.pdf

Young, M. F. D. (2010b). The future of education in a knowledge society: The radical case for a subject-based curriculum. Journal of the Pacific Circle Consortium for Education, 22(1), 21-32. Sótt af https://programs. crdg.hawaii.edu/pcc/PAE_22_1_final_10.pdf

Young, M. F. D. (2011). The return to subjects: A sociological perspective on the UK coalition government's approach to the 14-19 curriculum. Curriculum Journal, 22(2), 265-278. doi:10.1080/09585176.2011.574994

Porgerður Katrín Gunnarsdóttir. (2004). Brottfall úr framhaldsskóla [ræða á 131. löggjafarpingi, 13. fundi, 20. október 2004]. Sótt af http://www.althingi.is/altext/131/10/r20152153.sgml

Atli Harðarson. (2019),

Tvímælis: Heimspeki menntunar og skólakerfi nútímans

Netla - Veftímarit um uppeldi og menntun. Menntavísindasvið Háskóla Íslands.

Sótt af http://netla.hi.is/serrit/2019/tvimaelis_heimspeki/01.pdf

DOI: https://doi.org/10.24270/serritnetla.2019.70 


\section{Nafnaskrá}

Akker, Jan van den $11^{1}$

Allyson Macdonald 2

Andri Ísaksson 1, 9

Aristóteles 1

Arrow, Kenneth 4

Atli Harðarson 2, 3, 5, 8, 9, 10, 11, 12

Au, Wayne 9

Bailey, Charles 3

Ball, Deborah Loewenberg 12

Barnett, Ronald 9

Barrow, Robin 2, 10

Beck, Ulrich 2

Berglind Rós Magnúsdóttir 8

Berlin, Isaiah 5

Bernstein, Basil 3

Biesta, Gert J. J. 12

Bjarni Harðarson I

Björgvin G. Sigurðsson 7

Bloom, Benjamin S. 9

Bobbitt, John Franklin 9, 10, 12

Bogi Th. Melsteð 1

Boisvert, Raymond D. 2

Bowen, James 1

Brien, Andrew 7

Broddi Jóhannesson 12

Brynjar Ólafsson 11

Bush, George W. 8

Campbell, Donald T. 7

Campbell, Elizabeth 12

Caplan, Bryan 4, 5, 8

Carr, David 12

Cicero, Marcus Tullius 2
Codd, John 7

Cooke, Sandra 12

Coulson, Andrew J. 1

Cuban, Larry 11

Darwin, Charles 8

Deneen, Patrick J. 8

Denti, Louis G. 11

Deresiewicz, William 3

Dewey, John 2, 3, 5, 7, 8, 9, 10, 12, E

Dóra S. Bjarnason 9

Du Bois, William E. B. 3

Dunne, Joseph 12

Eggert Lárusson 2

Einar Magnússon 1

Eisner, Elliot W. 1

Elliott, John 9

Entwistle, Harold 3

Fesmire, Steven 12

Fitzgerald, Tanya 7

Forzani, Francesca M. 12

Friedman, Milton 8

Furedi, Frank 3

Garrison, Jim 12

Gatto, John Taylor 5

Gentry, April 5

Gestur Guðmundsson 3

Gibboney, Richard A. 3

Goldstein, Dana 7

Goodhart, Charles A. E. 7

Gould, Stephen J. 3

Graeber, David 8

Greene, Maxine 9, 12, E

1 Tölur vísa til kafla bókarinnar. Táknið I merkir inngang en E eftirmála. 
Gretar L. Marinósson 9

Guðmundur Finnbogason 4

Guðmundur Heiðar Frímannsson 1

Guðni Guðmundsson 1

Gunnar M. Magnúss 1, 12

Gunnar Ragnarsson 5

Hafdís Ingvarsdóttir 2, 11, 12

Hallgrímur Pétursson 5

Hamilton, David 11

Hargreaves, David H. 12

Harpa Hreinsdóttir I

Hayek, Friedrich von 7

Hegel, Georg W. F. 8

Heimir Porleifsson 1

Helgi Skúli Kjartansson I, 12

Hermansen, Hege 12

Hermína Gunnpórsdóttir 9

Higgins, Ann 5

Higgins, Chris 12

Hinchliffe, Geoffrey 2

Holt, Maurice 9

Howlett, John 2

Hoyle, Eric 12

Hyland, Áine 9

Illich, Ivan 5,6

Ingveldur Geirsdóttir 7

Jackson, Philip W. 1, 2, 9, E

Jesús frá Nasaret 1, 5

Jón Árni Friðjónsson I

Jón Birgir Eiríksson 6

Jón Espólín 5

Jón F. Hjartarson 11

Jón Torfi Jónasson I, 4

Jónas Pálsson 12

Kant, Immanuel 2, 3

Karseth, Berit 9

Katz, Michael S. 11

Kellough, Noreen G. 6

Kellough, Richard D. 6

Kendall, John S. 6, 9

Kennedy, Declan 9

Klein, M. Frances 9

Kliebard, Herbert M. 1, 9
Kohlberg, Lawrence 5

Kotzee, Ben 2

Kristinn Ármannsson 1, 2, 5, 11

Kristján Kristjánsson 5

Kristjana Stella Blöndal 4

Labaree, David 12

Lagemann, Ellen C. 12

Laozi I

Lingard, Bob 7

Locke, John 2, 3, 5

Loftur Guttormsson 1, 12

Lowe, Roy, 7

Magnús Helgason 4, 12

Martino, Wayne 7

Marx, Karl 3

Marzano, Robert J. 6, 9

Maxwell, Bruce 12

McAllister, James 12

McKernan, James 12

McNeil, John D. 1

Melville, Herman 5

Meyvant Dórólfsson 2

Mill, John S. 3

Montaigne, Michel de 5

Moore, Rob 3

Moulin, Daniel 3, 5

Muller, Jerry Z. 7

Nussbaum, Martha C. 2

O'Hear, Anthony 2

O'Quinn, Elaine J. 12

Oakeshott, Michael 7

Oancea, Alis 12

Obama, Barach 8

Ólafur Páll Jónsson I, 1, 2, 5, 9

Ólafur Sigurðsson 7

Orchard, Janet 12

Paddock, Lisa 5

Páll Skúlason 5, 8, 10

Pelletier, Luc G. 12

Peters, Richard S. 9

Piaget, Jean 5

Pinar, William F. 9

Platon 1 
Polanyi, Michael 7

Popkewitz, Thomas S. 11

Power, F. Clark 5

Putnam, Hilary 2

Ravitch, Diane 8

Reagan, Ronald 8

Reid, William A. 9

Reynolds, William M. 9

Rezai-Rashti, Goli 7

Róbert Jack 5

Robinson, Wendy 12

Rollyson, Carl 5

Rousseau, Jean-Jacques 5

Ryan, Norma 9

Sahlberg, Pasi 11

Sarason, Seymour B. 11

Schiller, Friedrich 2

Schiro, Michael S. 1

Schwab, Joseph J. 9

Scott, James C. 6, 8

Sellar, Sam 7

Sen, Amartya 3

Seneca, Lucius A. 2

Sharp, Elizabeth C. 12

Short, Edmund C. 9

Sidwell, Marc 2

Sigrún Aðalbjarnardóttir 1

Sigrún Sif Jóelsdóttir 5

Sigurður Kristinsson 12

Sigurjón Mýrdal 12

Silverman, Sarah K. 12

Slattery, Patrick 9

Sockett, Hugh 12

Soltis, Jonas F. 1
Spence, Michael 4

Stefanía Helga Stefánsdóttir 11

Stenhouse, Lawrence 9, E

Stiglitz, Joseph 4

Strathern, Marilyn 6,7

Sveinbjörn Egilsson 5

Taba, Hilda 9, 11

Tabachnick, B. Robert 11

Tannhäuser, Anne-Christine 4

Taubman, Peter M. 9

Thatcher, Margaret 8

Dóra Björg Sigurðardóttir 5

Dorgerður Katrín Gunnarsdóttir 7

Thorndike, Edward L. 12

Tolstoj, Leo 3, 5

Tooley, James 1, 8

Tyack, David 11

Tye, Barbara B. 11

Tyler, Ralph W. 9

Vallance, Elizabeth 1

Voltaire (François M. Arouet) 2, 5

Walker, Decker F. 1

Warnick, Bryan R. 12

Wehlage, Gary 11

West, Edwin G. 1, 8

Westbrook, Robert B. 2

White, John 1, 2, 9, 11

Williams, Bernard 5

Winch, Christopher 9

Winstanley, Carrie 7

Wolfgang Edelstein 5, 12

Woolhouse, Roger 2

Young, Michael F. D. 3 